RAFAEL SILVA IZAIAS

\title{
A LEGITIMAÇÃO DO ESTADO DEMOCRÁTICO DE DIREITO NA MODERNIDADE PERIFÉRICA uma observação a partir do caso brasileiro.
}

\author{
DISSERTAÇÃO DE MESTRADO
}

Orientador: Prof. Titular Tércio Sampaio Ferraz Jr.

Faculdade de Direito da Universidade de São Paulo

São Paulo 2010 
RAFAEL SILVA IZAIAS

\section{A LEGITIMAÇÃO DO ESTADO DEMOCRÁTICO DE DIREITO NA MODERNIDADE PERIFÉRICA uma observação a partir do caso brasileiro.}

Dissertação apresentada como requisito para a obtenção do título de Mestre em Filosofia e Teoria Geral do Direito pelo Programa de PósGraduação da Faculdade de Direito da Universidade de São Paulo, sob orientação do Prof. Titular Tércio Sampaio Ferraz Jr.

Faculdade de Direito da Universidade de São Paulo

São Paulo 2010 
Banca Examinadora

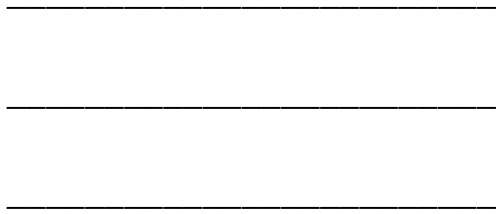




\section{AGRADECIMENTOS.}

Agradeço ao meu orientador, Professor Tércio Sampaio Ferraz Jr., por acreditar no projeto e na minha capacidade de desenvolvê-lo. Também agradeço à sua secretária Mônica, pela gentileza durante o atendimento a este orientando.

Aos Professores Eduardo Bittar e Elza Boiteux, pelos comentários e apontamentos feitos durante o exame de qualificação.

Ao Professor Marcelo Neves, exemplo de dedicação e amor à atividade acadêmica, pela constante disposição para o diálogo e pelo fornecimento de material para o trabalho. Também agradeço à sua secretária Siméia Azevedo pela doçura e gentileza ao atender os meus pedidos de contato e disponibilização de material.

Ao Professor Celso Campilongo - de quem tive a honra de ser monitor - pela disposição para o diálogo, pelo comprometimento com o SAJU-USP (Serviço de Assessoria Jurídica da Faculdade de Direito da Universidade de São Paulo, projeto de extensão do qual fui membro durante os primeiros anos de graduação) e pela disponibilização de material.

À Fundação de Amparo à Pesquisa do Estado de São Paulo, cuja bolsa me proporcionou a dedicação integral à pesquisa pelo período de dois anos.

Aos amigos do Grupo "Direito na Sociedade Mundial", coordenado pelo Professor Marcelo Neves, a quem desejo sorte na vida pessoal e na promoção de uma compreensão mais adequadamente complexa de nossa sociedade, especialmente ao amigo Pedro Henrique Ribeiro, pelas valiosas discussões e pelo fornecimento de material sobre ciências políticas.

Ao Grupo "Democracia, Justiça e Direitos Humanos", coordenado pelo Professor Eduardo Bittar, pelas inúmeras oportunidades de discussão e pelo aprendizado que sempre me proporcionou. 
Aos Concurseiros, pela companhia diária e pelos cafés na CAASP, responsáveis por transformar as tardes de estudo em momentos muito mais agradáveis. Os nossos destinos se conectaram durante esse convívio e desejo a todos que sejam aprovados!

Aos queridos amigos Gustavo Dantas Ferraz, exemplo de serenidade e Promotor (com $p$ maiúsculo) de uma sociedade mais justa, pelo incentivo e por ter lido e comentado a dissertação, Priscila Pivatto, pela valiosa ajuda e incentivo durante todo esse período, e Bruno Simões, com quem muito aprendo a cada diálogo.

À minha família, que fez por mim muito mais do que eu serei capaz de retribuir. Nenhuma palavra poderá expressar a minha gratidão.

A Alana, por TUDO. You are my center when I spin away out of control. 


\section{SUMÁRIO.}

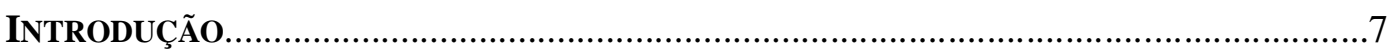

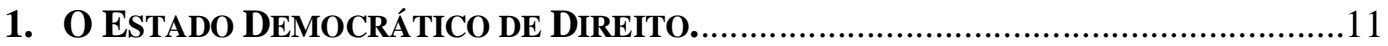

1.1.A Política como Sistema Funcional......................................................................11

1.2.A Diferenciação Funcional entre a Política e o Direito........................................14

1.3.O Poder como Meio de Comunicação Simbolicamente Generalizado.................19

1.4.A Circulação e a Contracirculação do Poder na Democracia..............................23

1.5.Os Procedimentos do Estado Democrático de Direito........................................29

2. A LegitimaÇÃo das Decisões do Estado Democrático de Direito.............39

2.1.A Legitimidade como Fórmula de Contingência do Sistema Político..................42

2.2.A Legitimidade Enquanto Aceitação e a Legitimação pelo Procedimento..........47

2.3.A Destautologização do Conceito de Legitimidade............................................. 56

2.4.O Ciclo de Legitimação do Estado Democrático de Direito...............................62

2.5.A Justiça Procedimental.......................................................................................64

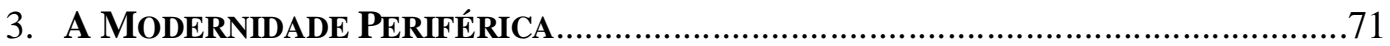

3.1.Modernidade e Diferenciação Funcional...........................................................72

3.2.Modernidade Central e Modernidade Periférica................................................78

3.3.A Realidade Brasileira como Realidade Periférica............................................8

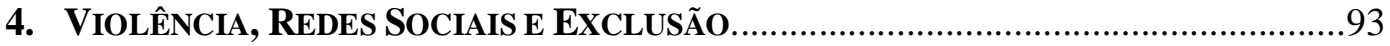

4.1 A Violência nas Interações Sociais: o "Código do Sertão"................................93

4.2. As Redes Sociais e as Expectativas Sociais...................................................96

4.3. As Redes Sociais e o Estado Democrático de Direito.......................................105

4.4. Corrupção, Exclusão e o Estado Democrático de Direito..................................114

5. Apontamentos sobre a LegitimaÇão do Estado Democrático de Direito

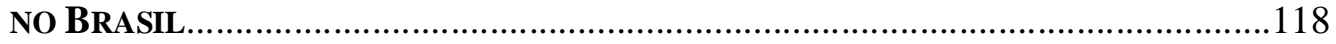

5.1. Direitos Sociais e Inclusão na Ordem Constitucional de 1988 .......................118

5.2. O Estado Democrático de Direito e a Escassez................................................123

5.3. Os Limites da Legitimidade do Estado Democrático de Direito no Brasil......134

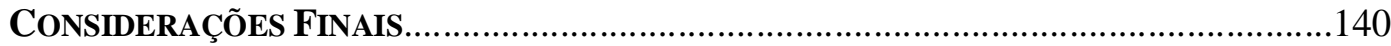

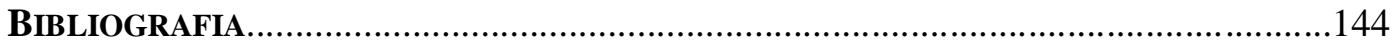




\section{INTRODUÇÃO.}

Em seu artigo Problems, Methods and Theories in the Study of Politics, Ian Shapiro critica o fato de os estudos dos fenômenos políticos não serem suficientemente dirigidos por problemas, mas por teorias ou métodos ${ }^{1}$. Certamente, o mesmo pode ser dito acerca do estudo dos fenômenos jurídicos, com o agravante de que nesta área os estudos sociológicos são raros e insipientes. Segundo Shapiro, a pesquisa que não é dirigida por um problema específico perde valor cognitivo, tornado-se trivial, tautológica e não-falseável ${ }^{2}$. Os seus resultados correm o risco de tornarem-se restritos ao público acadêmico que compartilha dos valores e dogmas defendidos pelo cânone teórico adotado.

Ao mesmo tempo, como salientam Wittgenstein, Austin e Kuhn, a teoria se faz necessária pelo fato de não existir abordagem pré-teórica ou suprateórica. Como bem assevera Shapiro, "não existe descrição crua de fatos ou dados 3 ". A pesquisa dirigida por um problema não busca ratificar nenhuma teoria específica, mas compreender o

\footnotetext{
${ }^{1}$ Ian SHAPIRO, "Problems, Methods and Theories in the Study of Politics, or What's Wrong with Political Science and What to do About It". Political Theory, Vol. 30, n 4, 2002, pp. 596-619.

${ }^{2} \mathrm{O}$ conceito de falseamento foi formulado por Karl Popper e indica que uma teoria deve gerar enunciados sujeitos ao falseamento, ou seja, deve ser possível provar com clareza que eles são falsos. Embora Popper afirme que a sujeição ao falseamento distingue as teorias científicas das teorias não científicas, o mais correto seria afirmar que todas as teorias devem buscar aumentar o seu grau de falseamento, mesmo que elas não sejam propriamente teorias empíricas. Karl POPPER, A Lógica da Pesquisa Científica. São Paulo: Cultrix, 2006.

3 Ian SHAPIRO, "Problems, Methods and Theories in the Study of Politics, or What's Wrong with Political Science and What to do About It", p. 604.
} 
problema proposto a partir das teorias existentes, apontando quais viabilidades e limitações elas possuem para o cumprimento desse objetivo ${ }^{4}$.

O presente trabalho, embora esteja inserido no âmbito da teoria da sociedade, e não no âmbito das ciências sociais empíricas, pretende ser dirigido por um problema específico. A principal pergunta que ele busca responder é a seguinte: quais as dificuldades adicionais de legitimação encontradas pelo Estado Democrático de Direito nos chamados países periféricos? Quais desafios o contexto periférico, marcado pela exclusão e pela corrupção generalizada, traz para a manutenção da democracia e para a reprodução das instituições políticas e jurídicas? Sem a pretensão de esgotar um tema tão complexo, procuramos analisar essas dificuldades e desafios.

O cânone teórico adotado é a teoria dos sistemas de Niklas Luhmann. Por tratarse de uma teoria da sociedade, de caráter funcional-estruturalista, adotá-la como marco teórico implica buscar compreender não apenas os mecanismos internos do Estado Democrático de Direito, ou seja, não apenas os mecanismos internos da política e do direito e a relação entre política e direito. Mais do que isso, busca-se compreender a função que a política e o direito desempenham perante a sociedade como um todo, e como as condições históricas locais influenciam as operações desses sistemas funcionais.

A análise do problema proposto, a partir da observação do caso brasileiro, se dará da seguinte maneira. O primeiro capítulo busca definir o Estado Democrático de Direito a partir da teoria dos sistemas. O Estado Democrático de Direito, compreendido tradicionalmente como uma unidade, é na verdade o resultado da diferenciação de dois sistemas funcionais: o sistema político e o sistema jurídico. O primeiro capítulo também trata dos quatro procedimentos do Estado Democrático de Direito (eleitoral, legislativo, administrativo e judicial) e da troca de prestações legitimatórias entre o sistema político e o sistema jurídico.

O segundo capítulo trata do tema da legitimidade. O grande desafio das abordagens sociológicas, segundo Robert Grafstein, consiste em fornecer um conceito

\footnotetext{
4 “[...] the problem-driven scholar asks, "Why are constitutions enacted?" or "Why do they survive?" and "Why do ideologies develop?" or "Why do people adhere to them?". She then looks to previous theories that have been put forward to account for these phenomena, tries to see how they are lacking, and whether some alternative might do better". Ian SHAPIRO, "Problems, Methods and Theories in the Study of Politics, or What's Wrong with Political Science and What to do About It", p. 603.
} 
de legitimidade que seja empiricamente verificável e que não seja tautológico. Nesse sentido, o capítulo busca definir a legitimidade como aceitação das decisões estatais. A criação de procedimentos juridicamente estruturados que pretendem ser seguros, equitativos e acessíveis é o principal mecanismo utilizado pelo Estado Democrático de Direito para garantir a aceitação das suas decisões (legitimação pelo procedimento), mesmo quando existe discordância em relação ao seu conteúdo, fato confirmado pelos estudos empíricos da tradição estadunidense da justiça procedimental.

O terceiro capítulo trata do tema da modernidade periférica. Identificamos o surgimento da modernidade a partir do processo de emergência dos sistemas funcionais, iniciado na Europa entre o século XVI e o século XVIII. Os desenvolvimentos da sociedade criaram desde então uma divisão entre modernidade central - caracterizada pela inclusão generalizada e pela plena realização da diferenciação funcional - e modernidade periférica (na qual se insere o Brasil) - caracterizada pelo alto índice de exclusão e pela instabilidade da diferenciação funcional. Essa divisão, baseada em tipos ideais weberianos, não é incompatível com análises que reduzem a escala de observação com o objetivo de compreender localidades centrais ou periféricas específicas.

O quarto e o quinto capítulos tratam das condições históricas e estruturais que prejudicam o desempenho e a legitimação do Estado Democrático de Direito no contexto periférico, mais especificamente o contexto brasileiro. No quarto capítulo, defendemos que as redes sociais de favorecimento e corrupção - endêmicas na realidade brasileira - reproduzem um padrão personalista de interação social que prejudica a generalização congruente das normas jurídicas e dos papéis sociais necessários à manutenção de instituições complexas e estruturadas. A corrupção e ineficácia dos direitos fundamentais (sobretudo os sociais) corroem a confiança do público nas instituições estatais, encarecem as políticas públicas e reproduzem a exclusão e a desigualdade.

O quinto capítulo procura discutir os fatores estruturais que prejudicam o desempenho do Estado Democrático de Direito na modernidade periférica. Os Estados periféricos são muito mais vulneráveis à escassez, que é um estado do sistema econômico que não pode ser política ou juridicamente controlado. O Brasil aumentou a sua carga tributária e os seus gastos sociais a partir da Constituição de 1988, obtendo melhoras significativas nos indicadores sociais. Apesar disso, o país ainda é marcado 
pela exclusão e pela desigualdade (a segunda pior do mundo), responsáveis pela eclosão de tensões sociais que constituem limites claros à legitimidade do Estado Democrático de Direito. 


\section{O ESTADO DEMOCRÁTICO DE DIREITO.}

Die funktional differenzierte Gesellschaft operiert ohne Spitze und ohne Zentrum.

(A sociedade funcionalmente diferenciada opera sem topo e sem centro).

Niklas Luhmann

\subsection{A Política como Sistema Funcional.}

A sociedade atual é uma sociedade funcionalmente diferenciada, composta por sistemas funcionais que respondem a preocupações específicas e que não possuem nenhuma relação de hierarquia entre si. A política não pode mais ser compreendida (se é que tal compreensão algum dia correspondeu à realidade) como o centro que planeja e regula toda a sociedade. O Estado, como afirmou Hegel, não representa mais "a base e o centro de todos os elementos concretos da vida de um povo: da arte, do direito, da moral, da religião e da ciência ${ }^{5}$.

\footnotetext{
${ }^{5}$ Friedrich HEGEL, Selections. New York: C. Scribner's Sons, 1929, p. 403.
} 
Uma teoria da sociedade que faça justiça à complexidade da sociedade moderna deve compreender o sistema político como um sistema funcional que atua paralela e horizontalmente a outros sistemas funcionais. Nesse modelo de sociedade sem topo e sem centro, está excluída a possibilidade de o sistema político atuar fora dos seus limites sem colocar em risco a autonomia dos demais sistemas funcionais. Também está excluída a possibilidade de as operações políticas serem determinadas diretamente pela operação de outros sistemas, como o sistema econômico, a partir de um esquema monocausalista.

Apesar das recentes transformações ocorridas na sociedade e da extensa bibliografia sobre o declínio dos Estados Nacionais, a política ainda é marcada pela permanência da ordem internacional vestfaliana, onde os Estados Nacionais são os atores principais ${ }^{6}$. No plano mundial, o sistema político se encontra segmentado em Estados Nacionais territorialmente delimitados. No plano nacional, por sua vez, o sistema político apresenta um padrão de diferenciação centro-periferia: o centro do sistema é composto pela administração pública (as organizações estatais), ao passo que a sua periferia é composta por partidos políticos, sindicatos, organizações nãogovernamentais, grupos de pressão, movimentos de protesto, etc. ${ }^{7}$

A visão da política como sistema funcional compreende os fenômenos políticos como fenômenos que não se resumem ao estatal e ao político-partidário. $\mathrm{O}$ sistema político não é composto apenas pela administração pública e pelos partidos políticos, mas também por inúmeras organizações não estatais e não partidárias. A administração pública (executivo e legislativo) constitui o centro do sistema, responsável pela produção de decisões coletivamente vinculantes, e não a sua totalidade. Os partidos políticos, por sua vez, constituem apenas um tipo específico de ator de político, dentre vários outros, responsável por fornecer pessoal para os cargos eletivos da administração pública e por condensar e testar chances de consenso, e cuja hegemonia vem sendo contestada pela emergência de novos atores políticos como as organizações nãogovernamentais e os movimentos sociais.

Apesar do fenômeno da globalização - ou mundialização - que produz uma maior interdependência entre as localidades e uma maior influência do plano global sobre o

\footnotetext{
${ }^{6}$ Alberto do AMARAL JÚNIOR, Introdução ao Direito Internacional Público. São Paulo: Atlas, 2008.

${ }^{7}$ Niklas LUHMANN, Die Politik der Gesellschaft. Frankfurt am Main: Suhrkamp, 2000, pp. 243-253.
} 
plano local, o horizonte de legitimação do sistema político ainda é primordialmente nacional, vinculado às esferas públicas nacionais e às decisões produzidas pelas organizações estatais. Por essa razão, as análises compreensivas ou empíricas da legitimação do sistema político (e, conseqüentemente, do Estado Democrático de Direito como um todo) são análises que devem se concentrar sobre o plano nacional.

Os pressupostos para a legitimação política ainda estão vinculados aos contextos regionais, não havendo perspectivas de uma política mundial abrangente que possa prescindir da formação de Estados; isto é, porque as chances para a tomada de decisões coletivamente vinculantes ainda permanecem fortemente dependentes de processos políticos que, em primeiro lugar, se desenvolvem no respectivo plano regional ${ }^{8}$.

Também é preciso ter em mente que o sistema político, assim como os demais sistemas funcionais, não é um mero conjunto de organizações, mas uma ordem social emergente, cujo surgimento pode ser identificado no tempo e no espaço ${ }^{9}$. Segundo Humberto Maturana, uma nova ordem emerge quando um processo cíclico se acopla a um processo linear, isto é, quando um processo cíclico é aplicado às conseqüências da sua aplicação prévia ${ }^{10}$. A emergência dos sistemas funcionais, mais especificamente, ocorre a partir do momento em que determinadas soluções para problemas sociais específicos são re-utilizadas repetidamente de maneira recursiva.

A peculiaridade de uma ordem emergente não pode ser compreendida a partir da sua redução a outra ordem na qual ela se "ancora". Não se pode compreender um organismo somente a partir dos processos que ocorrem no nível celular, por exemplo. ${ }^{11}$

\footnotetext{
${ }^{8}$ Marcelo NEVES, Transconstitucionalismo. Tese apresentada ao concurso de provas e títulos para provimento do cargo de Professor Titular na área de direito constitucional, junto ao Departamento de Direito do Estado da Faculdade de Direito da Universidade de São Paulo. São Paulo, 2009, p. 27.

9 “A emergência assinala precisamente a erupção de uma nova ordem, cujas características só podem ser compreendidas uma vez que essa nova ordem estiver constituída". Darío RODRÍGUES e Javier TORRES NAFARRATE, "Autopoiesis: La Unidad de una Diferencia: Luhmann y Maturana”. Sociologias, ano 5, n ${ }^{\circ}$, jan/jul 2003, p. 113.

${ }^{10}$ Humberto MATURANA e Bernhard PÖRKSEN, Del Ser al Hacer: los orígenes de la biologia del conocer. Santiago: JCSAEZ, 2004, p. 51.

${ }^{11}$ Um organismo é uma ordem biológica que emergiu a partir da ordem celular e que não pode ser compreendido como um mero agrupamento de células. $\mathrm{O}$ mesmo se aplica à consciência, ordem que emergiu do plano orgânico e que não pode ser compreendida como um mero conjunto de atividades de natureza orgânica. Os sistemas funcionais, por sua vez, são uma ordem social que emergiu da ordem das interações e da ordem das organizações durante o processo de diferenciação funcional ocorrido entre os
} 
Em oposição ao individualismo metodológico, portanto, o presente trabalho assume que os processos do sistema político não podem ser compreendidos somente a partir da dinâmica das suas interações e organizações, até mesmo porque essas interações e organizações se submetem às estruturas e imperativos funcionais do sistema. Trata-se de uma afirmação de crucial importância para a compreensão do processo de legitimação do Estado Democrático de Direito.

O sistema político, como os demais sistemas funcionais, é um sistema operativamente fechado e cognitivamente aberto: para se constituir enquanto sistema capaz de observar o seu ambiente, o sistema político necessita operar a partir de um código próprio, que nos regimes democráticos é o código governo-oposição. Em razão da sua relação de interpenetração ${ }^{12}$ com o sistema jurídico, o sistema político também possui um código secundário: o código jurídico lícito-ilícito. No próximo tópico, analisaremos com mais detalhes como se dá essa relação entre o sistema político e o sistema jurídico.

\subsection{A Diferenciação Funcional entre a Política e o Direito.}

O sistema político e o sistema jurídico aparecem comumente indiferenciados no discurso das ciências sociais sob o rótulo de Estado de Direito. Já o modelo de teoria social utilizado nesse trabalho considera que o Estado de Direito, na verdade, é formado por dois sistemas funcionais distintos: o sistema político e o sistema jurídico. Esses dois sistemas se diferenciaram no curso da evolução social e se converteram em sistemas que operam com critérios distintos e que desempenham funções distintas na sociedade.

séculos XVI e XVIII. Sobre esse assunto, as considerações de Niklas Luhmann em La Sociedad de la Sociedad, Ciudad de México: Herder, 2007, pp. 560-598.

${ }^{12}$ A interpenetração ocorre quando um sistema coloca a sua complexidade a serviço da construção da complexidade do outro. Niklas LUHMANN, Social Systems. Stanford: Stanford University Press, 1995, pp. 210-254. 
Enquanto a política se ocupa da produção de decisões coletivamente vinculantes, o direito se ocupa da generalização congruente de expectativas normativas ${ }^{13}$.

Não obstante a sua autonomia operacional, a política e o direito possuem uma relação estreita e recíproca de suporte e aprendizado. Existem estruturas e processos políticos que são extremamente relevantes para o sistema jurídico, assim como existem estruturas e processos jurídicos que são extremamente relevantes para o sistema político. Política e direito se encontram envolvidos numa rede de prestações recíprocas: enquanto o poder político é necessário para garantir a estrutura organizacional do judiciário e a obrigatoriedade das decisões jurídicas, a diferença entre o lícito e o ilícito, operada pelos tribunais, é necessária para que o poder político possa alcançar níveis mais altos de complexidade.

A autonomia do direito frente à política é uma aquisição recente e ainda relativamente instável da sociedade, consolidada somente no século XX. O início desse processo, no entanto, data das limitações ao poder monárquico ocorridas no século XVIII. No século XVII, principalmente nos escritos de Hobbes, a autoridade política e a autoridade legal ainda se encontravam unidas na figura do soberano ${ }^{14}$. Somente através do soberano os indivíduos se constituíam como sujeitos políticos e sujeitos de direito, e o Estado era visto como uma entidade ao mesmo tempo política e jurídica. A lei encontrava-se subordinada à política e constituía uma expressão das relações de poder existentes. Além disso, os súditos não possuíam nenhum direito reconhecido de resistir às ações do soberano.

Montesquieu denominou essa realidade rule by law: a lei era um instrumento do soberano e o soberano a ela não se submetia. Como inexistiam limitações legais às suas ações, os comandos legais coexistiam com comandos extralegais e ambos possuíam força semelhante. A rule by law visava a concentração do poder, e não a sua limitação através do direito. Isso só veio a acontecer posteriormente, com a rule of law. A rule of law surge a partir do momento em que o soberano restringe voluntariamente o seu

\footnotetext{
${ }^{13}$ Niklas LUHMANN, Die Politik der Gesellschaft. University Press, 2004.

${ }^{14}$ Thomas HOBBES, Leviathan. Oxford: Blackwell, 1946. Law as a Social System. Oxford: Oxford
} 
próprio poder, tornando o seu exercício previsível e obtendo dessa forma a cooperação voluntária da burguesia ascendente ${ }^{15}$.

Ao estabelecer leis que devem ser obedecidas por todos - inclusive pelo soberano - e aplicadas pelos tribunais de forma independente, a rule of law possibilitou que na Europa e na América do Norte o sistema jurídico emergisse como um sistema funcional autônomo, capaz de criar e administrar os seus próprios critérios de aplicação do direito. A aplicação do direito torna-se uma atividade especializada, exercida por juristas dotados de uma formação educacional específica. Além disso, o ressurgimento dos estudos sobre o direito romano e as codificações do final do século XVIII e início do século XIX possibilitaram o desenvolvimento de conceitos e tipos abstratos e gerais que formam uma linguagem especializada, que se diferencia da linguagem comum ${ }^{16}$.

O conceito de Estado de Direito (Rechtsstaat) nasce legatário do momento no qual os Estados europeus buscavam consolidar a sua soberania e obter o monopólio da produção e da administração do direito. No modo de pensar daquela época, não fazia sentido conceber a iurisdictio separada do imperium, o que equivaleria a um poder sem direito e a um direito sem capacidade de imposição ${ }^{17}$. O Estado de Direito era concebido apenas como um modelo de limitação do poder pelo direito, e não pressupunha a criação das leis por um procedimento democrático, o que só veio a acontecer posteriormente, momento a partir do qual o Estado passa a ser caracterizado como Estado Democrático de Direito.

Quem pretende utilizar o conceito de Estado de Direito (bem como os seus correlatos e derivados), portanto, deve ter em mente que ele surgiu como indicador de uma unidade funcional entre direito e política que não existe mais. Atualmente, tal conceito só faz sentido caso pretenda indicar justamente o contrário: a autonomia operacional do direito em relação à política e a autonomia operacional da política em relação a domínios funcionais como a religião e a economia ${ }^{18}$. Trata-se de um conceito que permanece útil para compreender as interdependências existentes entre o sistema

\footnotetext{
${ }^{15}$ Stephen HOLMES, Lineages of the Rule of Law, in José María MARAVALL e Adam PRZEWORSKI (Eds.), Democracy and the Rule of Law. Cambridge: Cambridge University Press, 2003, pp. 19-61.

${ }^{16}$ María José Fariñas DULCE, La Sociologia del Derecho de Max Weber. Madrid: Civitas, 1991, pp. 336353.

${ }^{17}$ Niklas LUHMANN, Law as a Social System, p. 358

${ }^{18}$ Marcelo NEVES, "Die Staaten im Zentrum und die Staaten an der Peripherie: Einige Probleme mit Niklas Luhmanns Auffassung von den Staaten der Weltgesellschaft". Soziale Systeme: Zeitschrift für soziologische Theorie 12. Stuttgart: Lucius \& Lucius, 2006, p. 250.
} 
político e o sistema jurídico. O direito (principalmente o direito privado) só pode se desenvolver se a paz estiver politicamente garantida, ou seja, se a violência for evitada (basta observar o caso das favelas brasileiras ${ }^{19}$ ). A política, por sua vez, garante a coação necessária para imposição das decisões jurídicas e, ao mesmo tempo, se beneficia da diferença entre o lícito e o ilícito administrada pelo sistema jurídico: o poder político busca ser exercido em conformidade com o direito.

Caso o governo pudesse determinar segundo critérios de conveniência política o que é lícito e o que é ilícito e interferir diretamente no funcionamento dos tribunais, não poderíamos falar na existência de um sistema jurídico autônomo. Nesse caso, haveria uma sobreposição entre o código político (governo-oposição) e o código jurídico (lícitoilícito). Lícito seria somente o que corresponde à vontade do governo. Aquilo que se opõe a ela passaria a ser ilícito e criminalizado. O governo estaria sempre respaldado pelo direito, pois controlaria politicamente a sua aplicação. Nesse caso, não estaríamos diante da existência da rule of law e nem da democracia, que pressupõe a possibilidade efetiva de exercer oposição sem ser criminalizado por isso.

Um sistema jurídico autônomo não pode ser compreendido como mero implementador de programas políticos, não importa o quanto as decisões dos tribunais se guiem por conseqüências políticas consideradas desejáveis ${ }^{20}$. As decisões judiciais são produzidas a partir da liberdade interpretativa dos juízes e do sentido gerado no interior do próprio sistema jurídico, seja pela atividade dos tribunais ou pela atividade dos doutrinadores. Qualquer teoria que pretenda auxiliar a aplicação do direito por meio de conceitos oriundos de outros domínios funcionais - como a análise econômica do direito - só pode se tornar juridicamente relevante caso reespecifique esses conceitos de forma a atender a problemas próprios do direito, respeitando os seus pressupostos operacionais. Mesmo assim, essas teorias são freqüentemente acusadas de tentar "colonizar" o direito com racionalidades que lhe são estranhas e que desconsideram a sua complexidade. ${ }^{21}$

\footnotetext{
${ }^{19}$ Niklas LUHMANN, Law as a Social System, pp. 370-371. Também existe o contexto contraditório onde a violação do direito e a corrupção são capazes de manter a ordem social, embora num nível reduzido.

${ }^{20}$ Niklas LUHMANN, Law as a Social System, p. 365.

${ }^{21}$ Nesse sentido, a seguinte afirmação de Gunther TEUBNER: "just like the legal discourse, the economic discourse also enslaves the world in its entirety - including events far away from economics like love, religion or the law - in assessing them all as cost factors and submitting them, even if under the mute protest of the enslaved rationalities, as now comparable itens to the economic calculus". "Altera Pars
} 
Entre a formulação das leis pelo sistema político e as decisões dos tribunais não existe uma relação causal simples e muito menos uma relação lógico-dedutiva. Em países onde o sistema jurídico é autônomo, não é possível ter certeza sobre a maneira como os tribunais irão aplicar uma lei recém-promulgada (e nem intervir diretamente na sua aplicação ${ }^{22}$ ). Os demais sistemas podem somente nutrir expectativas em relação à atuação dos tribunais e irritar externamente o sistema jurídico. Marcelo Neves fala também na possibilidade de construção de pontes de racionalidade transversal entre o sistema jurídico e os demais sistemas funcionais, voltadas à criação de interferências cognitivas (e não operativas) de mútuo aprendizado e que buscam combater o "autismo operacional", que torna o direito alheio às expectativas do restante da sociedade.

Os entrelaçamentos promotores de racionalidade transversal servem sobretudo ao intercâmbio e aprendizado recíprocos entre experiências com racionalidades diversas, importando a partilha mútua de complexidade preordenada pelos sistemas envolvidos e, portanto, compreensível para o receptor (interferência estável e concentrada no plano das estruturas) $)^{23}$.

O Estado Democrático de Direito é marcado não só pela existência de relações entre o sistema político e o sistema jurídico, mas pela existência de um tipo específico de relação. O sistema político institucionaliza o código jurídico (lícito-ilícito) como código secundário, ou seja, a diferença entre lícito e ilícito passa a estruturar e orientar a utilização do poder (nesse sentido, o Estado de Direito também pode ser definido como relevância da diferença lícito-ilícito para o sistema político ${ }^{24}$ ). Ao mesmo tempo, o sistema político disponibiliza o poder para a estruturação organizacional dos tribunais, e continua detendo a prerrogativa da promulgação de leis.

Audiatur: Law in the Collision of Discourses". In: Richard RAWLINGS (Ed.), Law, Society and Economy. Oxford: Oxford University Press, 1997, pp. 167-168.

22 "Government and public administration, [...] is from top to bottom an organization of the political system. It realizes politics, not law - even though the question may be asked at any time whether this is lawful or unlawful. With this question, however, communication changes its system reference". Niklas LUHMANN, Law as a Social System, pp. 374-375.

${ }^{23}$ Marcelo NEVES, Transconstitucionalismo, pp. 43-44.

${ }^{24}$ Nas últimas décadas, também é possível observar o aumento da importância da tecnificação adicional do código jurídico levada a cabo através da diferença constitucional-inconstitucional. 
O Estado Democrático de Direito deve ser compreendido como um modelo de circularidade procedimental. Ao mesmo tempo em que o sistema jurídico se submete à legislação politicamente estatuída, o sistema político se submete ao direito administrado pelos tribunais. Essa circularidade procedimental é estabelecida pela Constituição, que representa um elemento comum à política e ao direito ou, na terminologia da teoria dos sistemas, um acoplamento estrutural entre o sistema político e o sistema jurídico ${ }^{25}$.

A circularidade resulta em prestações recíprocas entre os dois sistemas: assim como o direito normatiza procedimentos eleitorais e parlamentares, regula organizações partidárias e estabelece competências e responsabilidades jurídicas dos agentes políticos, a política decide legislativamente sobre a entrada de novas estruturas normativas no sistema jurídico. Mas a circularidade típica do Estado de Direito significa, sobretudo, uma acentuada interpenetração entre os sistemas jurídico e político: o direito põe a sua própria complexidade à disposição da autoconstrução do sistema político e vice-versa ${ }^{26}$.

\subsection{O Poder como Meio de Comunicação Generalizado.}

Uma comunicação, quando compreendida, pode ser aceita ou rejeitada. Quando essa comunicação é um comando, surge sempre a pergunta: "por que obedecer?". Nas interações cotidianas e informais, a escolha entre a aceitação e rejeição de uma comunicação, na maioria das vezes, é determinada apenas pela linguagem: se alter fornecer boas razões, ego aceitará a comunicação. Caso contrário, ele a rejeitará. Habermas chamou isso de reprodução simbólica do mundo da vida (Lebenswelt),

25 "the constitution serves the dual function of including and excluding reciprocal perturbations of political and legal operations. Its two sided form of including and excluding influence maintains the separation of the systems and allows for separate autopoietic reproduction without any confusing overlap. It also characterizes the ways in which the legal system (and on the other side, the political system) avoids isolation (which means entropy) and constructs on its internal screen what can serve within the system as information". Niklas LUHMANN, "Operational Closure and Structural Coupling: the Differentiation of the Legal System”. Cardozo Law Review, n. 5, v. 13, march 1992, p. 1437.

${ }^{26}$ Marcelo NEVES, Entre Têmis e Leviatã: uma relação difícil. São Paulo: Martins Fontes, 2006, p. 92. 
instância da sociedade onde ocorrem as interações não especializadas e não sistêmicas ${ }^{27}$. Segundo Habermas, esse tipo de aceitação decorre da legitimidade (em sentido amplo) da comunicação.

Ocorre que na sociedade atual, em função da sua alta complexidade, a linguagem não representa o único mecanismo que orienta a escolha entre a aceitação e a rejeição das comunicações ${ }^{28}$. Os sistemas funcionais desenvolveram mecanismos complementares à linguagem voltados a aumentar a probabilidade de que as suas comunicações sejam aceitas. Esses mecanismos são os meios de comunicação simbolicamente generalizados ${ }^{29}$. No caso do sistema político, fica muito claro que as comunicações advindas da administração pública - ou seja, as decisões coletivamente vinculantes - não são obedecidas apenas porque concordamos com elas. Na maioria das vezes, obedecemos mesmo quando não concordamos. Embora um grau de consenso seja sempre necessário, o fato das decisões políticas e jurídicas encontrarem vinculação coletiva não pode ser explicado apenas pela anuência racional dos seus destinatários. Algumas correntes teóricas, como a marxismo, nem ao menos consideram a anuência dos destinatários o principal fator de obediência à lei.

Fica claro, portanto, que o sistema político é dotado de um mecanismo que torna os seus comandos menos vulneráveis à rejeição. Trata-se do poder, meio de comunicação simbolicamente generalizado que circula no interior do sistema. O poder aumenta significativamente a probabilidade de aceitação da comunicação que é difundida através dele ${ }^{30}$. Dessa forma, condutas que seriam altamente improváveis de outra maneira são coordenadas, possibilitando a obtenção de combinações que não surgiriam espontaneamente ${ }^{31}$. Graças ao poder existe o pagamento de tributos, o que dificilmente ocorreria caso eles fossem uma mera liberalidade, sujeita apenas à livre apreciação dos contribuintes.

O poder também pode ser utilizado para criar procedimentos que contribuem para a legitimação do sistema político e do sistema jurídico. Os cidadãos podem ou não

27 Jürgen HABERMAS, Theorie des Kommunikativen Handelns. Band 2: Zur Kritik der Funktionalistischen Vernunft. Frankfurt am Main: Suhrkamp, 1995.

${ }^{28}$ Niklas LUHMANN, Poder. Brasília: UNB, 1985, p. 6.

${ }^{29}$ Niklas LUHMANN, La Sociedad de la Sociedad, pp. 245-310.

${ }^{30}$ Niklas LUHMANN, Poder. Em sentido análogo, o trabalho pioneiro de Talcott PARSONS, "On the Concept of Political Power". Proceedings of the American Philosophical Society, Vol. 107, No. 3 (Jun. 19, 1963), pp. 232-262.

31 Javier TORRES NAFARRATE, Luhmann: La Política como Sistema. Ciudad de México: Fondo de Cultura Económica, 2004, p. 94. 
ser obrigados a participar deles: um réu não pode se esquivar de responder a uma ação judicial, por exemplo. Mas alguns resultados só podem ser alcançados através da participação em um procedimento específico: ninguém é obrigado a contratar com a administração pública, mas sob determinadas condições, quem desejar fazê-lo deverá se submeter obrigatoriamente ao procedimento licitatório.

Ao evoluir do uso direto da violência física para formas mais indiretas de obrigar o comportamento alheio, o poder se desprendeu da sua base material e passou a atuar no nível da comunicação simbólica ${ }^{32}$. A necessidade de intervir fisicamente para obter os resultados desejados cede lugar a mecanismos simbólicos como a ameaça de sanções negativas, a promessa de sanções positivas (incentivos, prêmios, etc.) e a absorção de incerteza. O conceito de absorção de incerteza é oriundo da teoria das organizações de March e Simon, e tem lugar quando uma organização estabelece uma rede recursiva de decisões e passa a se reproduzir em função dela ${ }^{33}$.

A absorção de incerteza ocorre quando inferências são efetuadas a partir de um corpo de evidências e as inferências, no lugar da própria evidência, são então comunicadas. Uma decisão não informa sobre o grau de incerteza existente no momento em que foi tomada: ela informa somente sobre a alternativa escolhida e, em menor grau, sobre as alternativas que foram deixadas de lado $^{34}$. Essa incerteza não poderá ser transmitida para as decisões posteriores, para as quais será relevante apenas o fato de ter havido uma decisão precedente. A decisão posterior não pode observar a incerteza da decisão anterior: dizemos que a segunda absorveu a incerteza da primeira ${ }^{35}$. Independentemente do grau de incerteza existente, essa incerteza será transformada, para as decisões posteriores, no mero fato de uma alternativa ter sido selecionada em detrimento de outras.

Além de contribuir para a autopoiesis das organizações políticas e jurídicas, a absorção de incerteza desempenha um papel crucial na legitimação do sistema político e do sistema jurídico, na medida em que torna menos visíveis as insuficiências decisórias das organizações políticas e jurídicas e menos provável a retomada de discussões sobre

\footnotetext{
32 Javier TORRES NAFARRATE, Luhmann: La Política como Sistema, p. 120.

${ }^{33}$ J.G. MARCH e H.A. SIMON, Organizations. New York: Blackwell Publishers, 1958, p. 65.

${ }^{34}$ David SEIDL, The Basic Concepts of Luhmann's Theory of Social Systems, in David SEIDL \& Kai BECKER (Eds.), Niklas Luhmann and Organizational Studies. Copenhagen: Liber \& Copenhagen Business, 2005, p. 39.

${ }^{35}$ David SEIDL, The Basic Concepts of Luhmann's Theory of Social Systems, p. 39.
} 
decisões já efetuadas. A decisão é dogmatizada: o seu conteúdo não pode ser negado, e há que se tomá-lo como ponto de partida para as decisões posteriores, mesmo quando se pretende decidir em sentido contrário.

As decisões [...] apesar de passageiras, devem ser utilizáveis como premissas para as decisões posteriores e, portanto, determinar quais determinações de sentido se encontram fixadas e onde se encontram os pontos críticos nos quais se planeja o decidir posterior em contradição com o decidir anterior ${ }^{36}$.

O poder pode ser utilizado de maneira instrumental ou simbólica, ou seja, para realizar ações concretas ou para criar ilusões de caráter político-legitimador. A utilização simbólica produz facilmente a impressão de que o poder é uma mera aparência, e traz a tentação de colocá-lo à prova. $\mathrm{O}$ excesso de simbolização gera descrença no poder e aumenta a necessidade de ações instrumentais. A utilização instrumental, por outro lado, conduz à pergunta sobre a legitimidade que o poder possui $^{37}$. Para se legitimar, o sistema político necessita encontrar um ponto de equilíbrio entre a utilização instrumental e a utilização simbólica do poder.

A necessidade de equilíbrio entre o instrumental e o simbólico evidencia o caráter paradoxal do poder: ele necessita tornar visíveis os meios que pode empregar e, ao mesmo tempo, deve evitar empregá-los. Ao contrário da infeliz frase de Mao Tse Tung, não é correto afirmar que o poder nasce do cano de um fuzil, embora com certeza ele se alimente da possibilidade de utilizá-lo o menor número de vezes possível. Para o poder, a eficácia autônoma dos seus comandos (observância) é muito mais vantajosa do que eficácia heterônoma (imposição ${ }^{38}$ ). No capítulo seguinte, veremos que o poder político é legítimo na medida em não necessita mobilizar esforços adicionais para que os seus comandos sejam obedecidos: a obediência ocorre de maneira espontânea.

\footnotetext{
${ }^{36}$ Niklas LUHMANN, Organización y Decisión. Autopoiesis, acción y entendimiento comunicativo. Tradução de Darío Rodrigues Mansilla. Rubí (Barcelona): Anthropos; México: Universidad Iberoamericana; Santiago de Chile: Instituto de Sociología, Pontificia Universidad Católica de Chile, 1997, p. 18. (Tradução livre).

${ }^{37}$ Nilkas LUHMANN, Die Politik der Gesellschaft, p. 32-33.

38 Para a diferença entre eficácia autônoma e eficácia heterônoma, ver Marcelo NEVES, $A$ Constitucionalização Simbólica. São Paulo: Martins Fontes, 2007, pp. 43-45.
} 
Sob a perspectiva das autoridades, a obediência voluntária à lei possui inúmeras vantagens. Se os agentes policiais e os juízes necessitam compelir o público a obedecer através da ameaça ou do uso da força, isso demandará uma enorme quantidade de recursos. A obediência voluntária custa bem menos e, por isso, é altamente valorizada pelas autoridades legais ${ }^{39}$.

\subsection{A Circulação e a Contracirculação do Poder na Democracia.}

Um dos motivos pelos quais o sistema político não pode ser compreendido como um simples conjunto de organizações diz respeito à complexa dinâmica de circulação e contracirculação de poder que ocorre em seu interior. Reconhecer que o poder possui uma dinâmica circular implica reconhecer que ele se constitui de maneira autoreferencial, e não a partir de critérios jusnaturalísticos ou transcendentais ${ }^{40}$. Também implica renunciar à busca de um foco único de onde emanaria todo o poder do sistema e, conseqüentemente, a sua legitimação.

Nos regimes democráticos, a circulação do poder se dá entre três elementos: público, política e administração pública ${ }^{41}$. O público é responsável pela escolha eleitoral de dirigentes e programas políticos e pela formação da opinião pública. A política (em sentido estrito) - que tem os partidos políticos como atores por excelência - condensa as reivindicações e anseios do público, possibilitando a produção de decisões coletivamente vinculantes ${ }^{42}$. A administração pública, por sua vez, formada pelo parlamento, pelo governo e pela burocracia administrativa, decide e vincula o público.

\footnotetext{
39 Tom R. TYLER, Why People Obey the Law. Princeton: Princeton University Press, 2006, p. 4 (tradução livre).

${ }^{40}$ Niklas LUHMANN, "Machtkreislauf und Recht in Demokratien". In: Zeitschrift für Rechtssoziologie 2, 1981, p. 164.

${ }^{41}$ Niklas LUHMANN, "Machtkreislauf und Recht in Demokratien".

${ }^{42}$ Niklas LUHMANN, "Machtkreislauf und Recht in Demokratien".
} 
Esse processo de circulação é acompanhado de um processo de contracirculação $^{43}$. Os partidos políticos são dependentes das realizações da administração: o governo ressalta o lado positivo das suas ações, enquanto a oposição ressalta o seu lado negativo. O público é dependente da pré-seleção de pessoas e programas no âmbito dos partidos políticos. A administração, na medida em que busca realizações cada vez mais complexas, depende da colaboração voluntária do público e, por isso, tende a conceder-lhe influência ${ }^{44}$.

A influência do público sobre a administração não se resume a manifestações $a$ posteriori sobre o conteúdo das suas decisões. O conceito de público como elemento meramente receptor e reativo - tal como formulado por Luhmann - não encontra correspondência na realidade democrática atual, onde o parlamento e o executivo estão submetidos a constantes pressões de um público que exige a tomada de determinadas decisões e até mesmo propõe pautas para deliberação ${ }^{45}$. Também proliferam os mecanismos de participação direta do público na administração - sem a intermediação dos partidos políticos - como o direito a voto ou voz em conselhos, comissões e outras instâncias governamentais ${ }^{46}$ e o orçamento participativo ${ }^{47}$.

Em inúmeros países está se vivenciando uma abertura do poder executivo à participação de atores societários - organizações civis - investidos juridicamente como representantes de determinados segmentos e interesses da população no desenho, na implementação e na supervisão de políticas públicas ${ }^{48}$.

\footnotetext{
${ }^{43}$ Niklas LUHMANN, "Machtkreislauf und Recht in Demokratien".

${ }^{44}$ Na obra Die Politik der Gesellschaft, Luhmann acrescenta um quarto elemento ao círculo: o povo. Consideramos, no entanto, desnecessária a distinção - meramente analítica - entre público enquanto receptor das decisões da administração e povo como o público que reage ativamente a essas decisões, pois trabalhamos com um conceito mais amplo de público, que engloba dinâmicas comunicativas ausentes na formulação luhmanniana.

${ }^{45}$ Roger COBB, Jennie-Keith ROSS, Marc Howard ROSS, “Agenda Building as a Comparative Political Process". The American Political Science Review, Vol. 70, No. 1 (Mar., 1976), pp. 126-138.

${ }^{46}$ No Brasil, o exemplo da obrigatoriedade das audiências públicas para a elaboração e fiscalização do plano diretor dos municípios (Lei 10.257/2001, art. 40, \$4º).

${ }_{47}$ Boaventura de Sousa SANTOS, "Orçamento Participativo em Porto Alegre: Para uma Democracia Redistributiva" in: Boaventura de Sousa SANTOS (org.), Democratizar a Democracia: Os Caminhos para a Democracia Participativa. Rio de Janeiro: Civilização Brasileira, 2002, pp. 457-559.

${ }^{48}$ Adrián Gurza LAVALLE, Peter P. HOUTZAGER e Graziela CASTELLO, "Representação Política e Organizações Civis: Novas Instâncias de Mediação e os Desafios da Legitimidade". Revista Brasileira de Ciências Sociais, Vol. 21, nº 60, fevereiro de 2006.
} 
O público é o papel social que pessoas, organizações ou movimentos sociais assumem durante a sua atuação na esfera pública. A esfera pública, por conseguinte, constitui o ambiente interno do sistema político, onde os atores políticos observam o estado de coisas do sistema e ao mesmo tempo obtêm informações sobre si mesmos, através da observação da repercussão das suas ações, ou seja, através da observação da maneira como terceiros observaram as suas observações ${ }^{49}$. A esfera pública desempenha para o sistema político uma função análoga à que o mercado desempenha para o sistema econômico.

Assim como os atores econômicos obtêm informações sobre os outros atores econômicos e sobre si mesmos observando o mercado, os atores políticos obtêm informações sobre os outros atores e sobre si mesmos observando a esfera pública. Através das interações que ocorrem no mercado e na esfera pública, o sistema econômico e o sistema político delimitam um campo de atuação possível, e as opções econômica ou politicamente inviáveis são excluídas ou tornadas improváveis.

No caso da política, essa delimitação normalmente se dá por exclusão, num sentido negativo, já que é mais fácil identificar decisões passíveis de desagradar o público do que decisões passíveis de agradá-lo. Obviamente, trata-se sempre de um cálculo político: decisões que desagradam fortemente uma pequena parcela do público, embora agradem moderadamente a sua maioria, podem ser politicamente mais perigosas do que decisões que agradam fortemente uma pequena parcela do público, embora desagradem moderadamente a sua imensa maioria ${ }^{50}$. Numa sociedade complexa e pluralista, o Estado não pode evitar o dissenso em torno do conteúdo das suas decisões, mas pode evitar a tomada de decisões passíveis de gerar dissensos intoleráveis.

A atuação do público na esfera pública produz a chamada opinião pública ${ }^{51}$. Uma opinião é sempre a mescla de um componente informacional com um componente valorativo: não se trata nem de informação pura e nem de afirmações valorativas

\footnotetext{
${ }^{49}$ Rudolph STICHWEH, "Die Entstehung einer Weltöffentlichkeit". In Hartmut KAELBLE, Martin KIRSCH e Alexander SCHMIDT-GERNIG (orgs.), Transnationale Öffentlichkeiten und Identitäten im 20. Jahrhundert. Frankfurt am Main: Campus, 2002, p. 60.

${ }^{50}$ Sobre a questão da intensidade das preferências, Robert DAHL, Um Prefácio à Teoria Democrática. Rio de Janeiro: Jorge Zahar, 1989, pp. 93-124.

51 “A opinião pública não é algo representativo no sentido estatístico. Ela não é um agregado de opiniões pesquisadas de forma individual ou privadamente manifestadas e, por isso, não deve ser confundida com os resultados de uma pesquisa de opinião". (tradução livre). Jürgen HABERMAS, Faktizität und Geltung: Beiträge zur Diskurtheorie des Rechts und des demokratischen Rechtsstaats. Frankfurt am Main: Suhrkamp, 1992, p. 438.
} 
$\operatorname{puras}^{52}$. Uma opinião é a valoração de um fato considerado relevante, como "a maioria da população considera abusivo o aumento da alíquota do imposto X”. A esfera pública, nesse sentido, também pode ser descrita como instância do sistema político onde são comunicadas opiniões ressonantes sobre a política e onde ocorre a especificação do papel social que as produz (o público). ${ }^{53}$

As esferas públicas das sociedades pluralistas são marcadas pela diversidade de valores, interesses e identidades e, por isso, o consenso conteudístico constitui um recurso escasso. A esfera pública política, portanto, não pode ser compreendida como uma arena para a busca de consensos, como na formulação de Habermas, mas como uma arena para o exercício do dissenso tolerável ${ }^{54}$. Isso não impede que existam convergências em meio ao dissenso, e também não impede que a opinião pública seja descrita através de esquematismos como opinião pública minoritária e opinião pública majoritária, ou opinião pública favorável ao governo e favorável à oposição.

$\mathrm{Na}$ esfera pública estão presentes comunicações tematizadas politicamente: comunicação não tematizadas politicamente são irrelevantes para o sistema político e se encontram em seu ambiente externo - ou seja, fora do sistema. A tematização política corresponde ao que Cobb, Ross e Ross denominam especificação, que é a conversão de reivindicações gerais em pautas deliberáveis ${ }^{55}$. A esfera pública funciona como uma espécie de "caixa de ressonância ${ }^{56 ", ~ o n d e ~ a s ~ r e i v i n d i c a c ̧ o ̃ e s ~ s u r g i d a s ~ n o s ~ n i ́ v e i s ~}$ interacionalmente mais distantes da administração pública procuram obter ressonância perante pessoas, organizações ou movimentos mais influentes ${ }^{57}$ e, conseqüentemente, perante a própria administração pública.

O conjunto de reivindicações com grande visibilidade e que despertam um alto grau de interesse do público forma a chamada agenda pública ${ }^{58}$. A agenda pública não

\footnotetext{
${ }^{52}$ Rudolph STICHWEH, “Die Entstehung einer Weltöffentlichkeit”, p. 61.

${ }^{53}$ Existem outros sistemas funcionais que desenvolveram esferas públicas, embora elas não cumpram para esses sistemas a mesma função que a esfera pública política cumpre para o sistema político. É possível falar na existência de uma esfera pública jurídica, de uma esfera pública esportiva, de uma esfera pública científica, e assim por diante. Rudolph STICHWEH, "Die Entstehung einer Weltöffentlichkeit", p. 59. Ver também as considerações históricas de Jürgen HABERMAS em Mudança Estrutural da Esfera Pública. Rio de Janeiro: Tempo Brasileiro, 2003.

${ }^{54}$ Marcelo NEVES, Entre Têmis e Leviatã: uma relação difícil, p. 132.

${ }^{55}$ COBB, ROSS e ROSS, "Agenda Building as a Comparative Political Process", p. 128.

${ }^{56}$ Jürgen HABERMAS, Faktizität und Geltung.

${ }^{57}$ Sobre o conceito de influência, Talcott PARSONS, "On the Concept of Influence". The Public Opinion Quarterly, Vol. 27, No. 1 (Spring, 1963), pp. 37-62.

${ }^{58}$ COBB, ROSS e ROSS, “Agenda Building as a Comparative Political Process", p. 126.
} 
se confunde com a agenda formal, composta pelos itens que os órgãos decisórios da administração elegeram formalmente para deliberação: nem tudo que é relevante para o público está na agenda da administração, e nem tudo que está na agenda da administração é relevante para o público. Cada localidade possui a sua própria agenda pública, e caso essa localidade seja parte de uma comunidade política mais ampla, que também possui a sua agenda pública, haverá sobreposição de itens ${ }^{59}$.

$\mathrm{Na}$ esfera pública circulam comunicações advindas de formadores de opinião, especialistas, organizações não-governamentais, grupos de pressão, partidos políticos, sindicatos, movimentos de protesto e de qualquer organização ou pessoa que se faça ouvir politicamente, inclusive as organizações econômicas e as organizações da própria administração. Durante a sua participação na esfera pública, esses atores assumem o papel de público, e as suas comunicações se tornam comunicações referencialmente políticas. Dessa forma, a esfera pública política se reproduz enquanto uma rede recursiva de comunicações, e o sistema político enquanto um sistema funcional autoreferencial e operacionalmente fechado ${ }^{60}$.

Os meios de comunicação de massa ocupam um papel de destaque na esfera pública. Eles atuam não só como condensadores e difusores da opinião pública, mas também como produtores, convertendo-se na principal fonte de informação e em local privilegiado de difusão de comunicações políticas. A concentração da difusão e da produção da opinião pública nos meios de comunicação de massa conduz a uma parcial profissionalização do papel de público, que passa a ser dominado pelos jornalistas e pelos especialistas que possuem acesso a eles ${ }^{61}$. Essa profissionalização aprofunda a assimetria no acesso à esfera pública. Mesmo com a emergência de novos canais de comunicação, como a internet, o sistema político ainda é fortemente dependente das notícias geradas pela grande mídia para observar a si mesmo ${ }^{62}$.

A dependência dos meios de comunicação de massa não é somente do sistema político, mas da sociedade como um todo, e representa uma conseqüência da

${ }^{59}$ COBB, ROSS e ROSS, “Agenda Building as a Comparative Political Process", p. 127.

${ }^{60}$ Esse conceito de esfera pública, baseado em Stichweh, torna desnecessário localizar a esfera pública no exterior do sistema político, enquanto "campo de tensão entre mundo da vida, de um lado, e sistemas político e jurídico, de outro", como faz Marcelo Neves (Entre Têmis e Leviatã: uma relação difícil, pp. 131-136).

${ }^{61}$ Rudolph STICHWEH, "Die Entstehung einer Weltöffentlichkeit”, p. 62.

${ }^{62}$ A mídia é composta por três atividades: noticiário (news), entretenimento e publicidade (advertising). Hans-Georg MOELLER, The Mass Media as a System, in Hans-Georg MOELLER, Luhmann Explained. Chicago e La Salle: Open Court, 2006, pp. 121-139. 
diferenciação funcional e da hipercomplexidade da sociedade. Numa sociedade hipercomplexa, torna-se impossível a observação direta da quase totalidade dos acontecimentos considerados relevantes. Por uma questão de custos de informação, estar bem informado depende cada vez mais de processos cognitivos alheios ${ }^{63}$. A maioria das observações sobre os atentados de 11 de setembro de 2001 e sobre a morte de Michael Jackson foram observações produzidas (e reproduzidas) pela mídia. Não fosse por isso, partes distantes do planeta não teriam acompanhado esses acontecimentos em tempo real, ou nem teriam obtido conhecimento deles.

Os meios de comunicação de massa atuam como fornecedores de uma realidade de fundo na qual os outros sistemas funcionais confiam ${ }^{64}$. Isso não significa que as comunicações da mídia obtenham validade imediata nos sistemas funcionais e que não possa haver reações críticas ao seu conteúdo. Ocorre que mesmo essas reações precisam ser selecionadas e retransmitidas pela mídia para se transformarem em comunicações socialmente abrangentes ${ }^{65}$. Dificilmente uma opinião se torna politicamente ressonante sem ter sido publicada por um veículo de comunicação de massa.

Em razão dessa dependência, as pessoas, organizações ou movimentos de protesto buscam adaptar a sua atuação política aos critérios que a grande mídia utiliza para selecionar e transmitir informações (como novidade, drama, conflito, sofrimento, dentre outros). Dessa forma, aumentam as chances de que os setores do público que se sentem desconsiderados pela mídia recorram a atos extremos e sensacionalistas como forma de atrair a atenção do público e, dessa forma, obter adesão aos seus valores e exigências $^{66}$. Apesar da sua crescente importância, a atuação da mídia como ator político não tem sido suficientemente analisada pelas teorias democráticas, que minimizam a questão da construção social de preferências, que ocorre na esfera pública, ou idealizam o processo comunicativo, ignorando os seus constrangimentos concretos ${ }^{67}$.

\footnotetext{
${ }^{63}$ Observações de segunda ordem, nas quais se observam observações efetuadas por terceiros. Niklas LUHMANN, La Sociedad de la Sociedad, pp. 475-476.

${ }^{64}$ Hans-Georg MOELLER, The Mass Media as a System, p. 31.

${ }^{65}$ Marcelo NEVES, Transconstitucionalismo, p. 27.

66 "Even if the new social movements stage large demonstrations with lots of bodies in the streets, we know about it through television, and some movements, such as Greenpeace, arrange their spectacular actions especially, and sometimes exclusively, for the media". Niklas LUHMANN e Stephen FUCHS, "What is the Case?" and "What Lies behind It?". The Two Sociologies and the Theory of Society". Sociological Theory, Vol. 12, No. 2 (Jul., 1994), p. 134.

${ }^{67}$ Luís Felipe MIGUEL, "Um Ponto Cego nas Teorias da Democracia: os meios de comunicação". Revista BIB, n. 49, 2000, p. 51.
} 


\subsection{Os Procedimentos do Estado Democrático de Direito.}

Os regimes democráticos atuais são caracterizados pela existência de procedimentos que selecionam e reproduzem relações específicas entre público, política e administração pública e entre o sistema político e o sistema jurídico. Esses procedimentos atuam como redutores de complexidade das decisões, pois selecionam o que é relevante e, dessa forma, excluem e neutralizam aquilo que não se pretende levar em conta. Para isso, eles protegem espaços de liberdade, criam liberdades artificiais, especificam papéis sociais ${ }^{68}$ e buscam neutralizar a influência dos papéis considerados irrelevantes ou indesejados.

O papel social de eleitor, por exemplo, constitui um papel social específico, que não se confunde com o papel social de pai, funcionário ou paciente de um hospital. $\mathrm{O}$ voto de cada eleitor possui o mesmo peso, independentemente de o eleitor ser um bom pai, um bom funcionário ou ter se comportado corretamente da última vez em que foi ao médico. Isso implica, por outro lado, que também existe a expectativa de que o eleitor não vote como se fosse um funcionário remunerado a serviço de determinados indivíduos. A proibição da compra e venda de votos é uma maneira de especificar o papel social de eleitor, delimitando-o frente aos demais papéis sociais.

Os procedimentos político-jurídicos constituem diferenciações internas do sistema político e do sistema jurídico e estabelecem premissas para a produção de decisões. Os procedimentos do Estado Democrático de Direito são instituídos e estruturados por normas jurídicas, seja através de normas válidas para todos os procedimentos (como os direitos fundamentais) ou de normas específicas para cada um deles. Um estudo sociológico desses procedimentos, no entanto, não deve se resumir à observação das normas que os compõem, pois a dinâmica das interações que se realizam em seu interior não pode ser explicada por fatores jurídicos. Além disso, a realidade de países periféricos como o Brasil demonstra - e isso será analisado no momento

\footnotetext{
${ }^{68}$ Um papel social é um conjunto de expectativas de comportamento que delimita o que é esperado de um ocupante de uma determinada posição social. Ralf DAHRENDORF, "Homo Sociologicus: Sobre a História, o Significado e os Limites da Categoria de Papel Social". In Ralf DAHRENDORF, Ensaios de Teoria da Sociedade. Tradução de Regina Lúcia M. Morel. Rio de Janeiro: Zahar, 1974, p. 46-53. Niklas LUHMANN, Sociologia do Direito. Rio de Janeiro: Tempo Brasileiro, 1983, Volume I, pp. 101 e ss.
} 
apropriado - que não é incomum que as decisões sejam tomadas à revelia das normas procedimentais.

A gênese dos procedimentos político-jurídicos reside no procedimento constituinte. O procedimento constituinte institui os demais procedimentos políticojurídicos e estabelece o limite de sua alteração por decisões posteriores. Ele reduz a complexidade das decisões políticas e jurídicas futuras ao delimitar uma moldura de alternativas decisórias constitucionais, excluindo uma série de alternativas consideradas inconstitucionais $^{69}$. O procedimento constituinte cria estruturas, que podem ser normativas ou cognitivas ${ }^{70}$.

As estruturas normativas são proibições deliberativas expressas presentes no texto constitucional, como as cláusulas pétreas ${ }^{71}$ e os direitos fundamentais (ou o seu conteúdo essencial ${ }^{72}$ ). Segundo Claus Offe, essas estruturas fixam juridicamente um raio de ação para o Estado, determinando quais matérias podem tornar-se objeto da ação estatal e, ao mesmo tempo, determinando os temas dos quais o Estado não se ocupa ${ }^{73}$. O direito de propriedade, exemplo citado pelo próprio Claus Offe, proíbe determinadas condutas e ao mesmo tempo obriga o Estado a tomar medidas que possibilitem o seu exercício, como o registro público de propriedade, a polícia e o judiciário.

A Constituição não se torna temporalmente vinculante para o sistema político e para o sistema jurídico somente através dos direitos fundamentais e das cláusulas pétreas. O procedimento constituinte também gera estruturas cognitivas, que são meras

69 "Las decisiones deben cotematizar la seletividad de su relación con otras decisiones. Esto han de hacerlo entonces con uma perspectiva doble de selección: eligen no sólo una de varias alternativas, sino que hacen esto en vistas a que, através de ello, éstas producen o impiden relaciones con otras decisiones". Niklas LUHMANN, Organización y Decisión, p. 17.

${ }^{70}$ Sobre as estruturas sociais, ver: Niklas LUHMANN, Sociologia do Direito, volume I, pp. 42-93. , Social Systems, pp. 278-356.

${ }^{71} \mathrm{O}$ art. $60, \S 4^{\circ}$, da Constituição Brasileira determina que não pode ser objeto de deliberação a proposta de emenda constitucional tendente a abolir "I - a forma federativa do Estado; II - o voto secreto, direto, universal e periódico; III - a separação dos Poderes e IV - os direitos e garantias individuais".

72 Sobre o conteúdo essencial dos direitos fundamentais: Robert ALEXY, Teoria dos Direitos Fundamentais. Tradução de Virgílio Afonso da Silva. São Paulo: Malheiros, 2008, pp. 295 e ss. Virgilio Afonso da SILVA, Direitos Fundamentais: conteúdo essencial, restrições e eficácia. São Paulo: Malheiros, 2009. Segundo Alexy, os direitos fundamentais "definem aquilo que o legislador legitimado democraticamente pode e aquilo que ele não pode decidir" (p. 447). Os limites normativos podem ser explícitos ou implícitos (lógicos) e não impedem totalmente o risco de dupla revisão (eliminam-se primeiramente os limites, para depois efetuar a alteração antes proibida). Acerca dessas questões, Virgílio Afonso da SILVA, "Ulisses, as Sereias e o Poder Constituinte Derivado: sobre a inconstitucionalidade da dupla revisão e da alteração no quorum de 3/5 para aprovação de emendas constitucionais". Revista de Direito Administrativo, $\mathrm{n}^{\circ}$ 226, 2001, pp. 11-32.

${ }^{73}$ Claus OFFE, Problemas Estruturais do Estado Capitalista. Rio de Janeiro: Tempo Brasileiro, 1984, p. 152. 
expectativas de que algo ocorrerá ou que não ocorrerá. As estruturas cognitivas tornam algumas alternativas decisórias extremamente improváveis através da própria manipulação das premissas decisórias e, dessa forma, a reprodução da estrutura é garantida sem que nenhum mecanismo complementar precise ser utilizado ${ }^{74}$. As estruturas constitucionais cognitivas atribuem uma série de ônus argumentativos ou de mobilização para aqueles que pretendem alterá-las.

$\mathrm{Na}$ terminologia do institucionalismo histórico, esse fenômeno é chamado de path dependence, e tem lugar quando uma alternativa selecionada passa a se reforçar ciclicamente, mesmo na ausência da força original que a criou, o que torna a sua alteração extremamente difícil $^{75}$. Os eventos geradores de path dependence são eventos críticos que criam trajetórias históricas que se auto-reproduzem. Um exemplo de path dependence gerada a partir da Constituição Brasileira de 1988 é a sobre-representação dos estados menos populosos no Congresso Nacional. Embora a Constituição não tenha vedado a modificação dos critérios para o cálculo do número de cadeiras, trata-se de algo improvável de ocorrer, pois depende da aprovação dos próprios estados sobrerepresentados.

Devido à sua importância como "critical juncture point" do sistema político e do sistema jurídico, em torno do procedimento constituinte democrático se aglutinam plexos de expectativas por cujo desapontamento se paga um alto preço: as constituições promulgadas sem o apoio generalizado do público são fadadas ao fracasso. Por isso, não é raro que interesses políticos divergentes cedam uns aos outros durante os trabalhos constituintes, mesmo que isso ocorra em detrimento da unidade lógica da constituição e sem atentar para as possibilidades de eficácia das normas constitucionais ${ }^{76}$.

Em torno do procedimento constituinte são nutridas expectativas de legitimidade semelhantes àquelas nutridas em relação aos demais procedimentos político-jurídicos, pois nos trabalhos constituintes busca-se justamente evitar que esses procedimentos

\footnotetext{
74 Na Assembléia Constituinte da França de 1789, propôs-se que cada estado detivesse um voto na futura Assembléia Nacional. Dessa forma, os dois primeiros estados, detentores de interesses semelhantes, excluiriam a contemplação dos interesses do terceiro estado. Nesse caso, tratou-se claramente de um ato intencional. Grande parte dos fenômenos, no entanto, é formada por efeitos imprevisíveis e latentes de decisões anteriormente tomadas.

75 James MAHONEY, "Path Dependence in Historical Sociology". Theory and Society, Vol. 29, No. 4. (Aug., 2000), pp. 507-548.

${ }^{76}$ Um exemplo prático na constituição brasileira é a inserção do inciso II do art. 185: ela pode ter agradado à bancada ruralista da assembléia constituinte, embora tenha criado uma antinomia, ao colidir com os artigos 184 e 186.
} 
"nasçam" eivados de "vícios" difíceis de sanar, ao menos no interior daquela ordem constitucional. Por isso, no intuito de conferir legitimidade ao procedimento constituinte, normalmente são utilizados ritos como a convocação de eleições para uma assembléia constituinte e a submissão da nova carta a um referendo, para que a população a aprove ou a rejeite.

[...] todo o complexo de atos - eleições, discussões, redações, votações, aprovação, publicação - necessários para se chegar ao "ato final" - a constituição - deve estruturarse em termos justos (due process) e adequados. Neste sentido se fala de legitimidade da constituição através do procedimento ${ }^{77}$.

O Estado Democrático de Direito possui quatro espécies de procedimento: o eleitoral, o legislativo, o administrativo e o judicial ${ }^{78}$. O procedimento eleitoral destinase a selecionar projetos políticos e pessoas para os cargos eletivos do governo, para um período pré-determinado. As escolhas eleitorais do público reduzem a complexidade das decisões políticas ao eliminar algumas propostas de governo e selecionar outras, que passam a configurar promessas eleitorais a serem cumpridas. Embora não solucionem os conflitos sociais, as eleições se prestam a trazê-los para o interior da administração pública $^{79}$.

O procedimento legislativo, por sua vez, é composto por comunicações que condensam e testam possibilidades de consenso e de apoio político, com vistas à formulação de leis e outros conteúdos normativos. O procedimento legislativo não se confunde com o parlamento ou com as normas constitucionais e regimentais que disciplinam a atuação dos parlamentares. Uma análise sociológica do procedimento legislativo também deve observar os costumes e convenções de "etiqueta parlamentar" que influenciam as decisões legislativas.

\footnotetext{
${ }_{77}^{77}$ José Joaquim Gomes CANOTILHO, Direito Constitucional. Coimbra: Almedina, 1993, p. 93.

78 Niklas LUHMANN, Legitimation durch Verfahren. Frankfurt am Main: Suhrkamp, 1983. Não consideramos o procedimento democrático-direto uma espécie autônoma de procedimento, já que ele não possui uma função autônoma e pode ser incluído no procedimento eleitoral (plebiscito e referendo), no procedimento administrativo (participação nos órgãos administrativos), no procedimento legislativo (orçamento participativo) ou no procedimento judicial (audiências públicas). Além disso, considerar toda participação como um tipo especial de procedimento inviabiliza uma análise de como esses quatro procedimentos podem se democratizar.

${ }^{79}$ Niklas LUHMANN, Legitimation durch Verfahren, pp. 162-163.
} 
Como consenso e apoio político são recursos escassos, as decisões legislativas dependem da articulação entre temas e momentos: para que os temas possam ser aprovados, eles devem ser votados no momento oportuno, e essa articulação nem sempre é feita aos olhos do público. Encontros a portas fechadas permitem que os partidos políticos tomem posições que não se coadunam com o seu programa partidário ou com o papel que deveriam desempenhar enquanto oposição. Também possibilitam a realização de permutas que se prefere esconder do público, de forma a preservar os símbolos que orientam a opinião pública ${ }^{80}$.

O procedimento administrativo (em sentido estrito), por sua vez, é bem mais difícil de definir do que os demais, pois a multiplicidade de órgãos administrativos, de normas que os estruturam e de funções que eles desempenham impedem a institucionalização de um tipo uniforme de procedimento ${ }^{81}$. Essa dificuldade fez com que o Direito Administrativo, nos seus primórdios, definisse o procedimento administrativo de forma negativa e residual: a administração (em sentido estrito) era toda atividade estatal que não era nem legislação e nem justiça ${ }^{82}$.

Essa definição negativa e residual pode ter sido apropriada para o início do século XX, momento no qual o Estado desempenhava muito menos tarefas do que na atualidade. A partir do momento em que surgem novos órgãos administrativos até então inexistentes e que desempenham atividades inéditas, no entanto, surge a necessidade de definir positivamente a função administrativa do Estado. Isso pode ser feito tanto a partir dos órgãos que a exercem (critério formal ou subjetivo) quanto a partir das atividades exercidas (critério material ou funcional). Para os propósitos do presente trabalho, definiremos o procedimento administrativo em termos funcionais como o procedimento responsável pela produção de decisões coletivamente vinculantes através de comportamentos infralegais ou, excepcionalmente, infraconstitucionais, submissos ao controle de legalidade do procedimento judicial ${ }^{83}$. Também incluímos no procedimento administrativo o chamado poder regulamentar, autorização para editar normas necessárias à execução das leis.

\footnotetext{
${ }^{80}$ Niklas LUHMANN, Legitimation durch Verfahren, p. 189.

${ }^{81}$ Niklas LUHMANN, Legitimation durch Verfahren, pp. 203 e ss.

82 "Pour toute l'activité qui n'est ni justice no législation, le mot administration s'est introduit, non pas pour remplacer celui de gouvernement, est placée à cote de la justice et forme comme celle-ci son opposé.” Otto MAYER, Droit Administratif Allemand. Paris, V. Giard \& E. Briére, 1903.

${ }^{83}$ Essa definição é baseada na definição dada por Celso Antônio BANDEIRA DE MELLO, Curso de Direito Administrativo. São Paulo: Malheiros, 2007, p. 36.
} 
Sobre o procedimento judicial, por fim, cumpre afirmar que o mesmo não é um procedimento do sistema político, mas um procedimento do sistema jurídico. Como dito anteriormente, o sistema político e sistema jurídico são sistemas funcionais que desempenham funções distintas (respectivamente, a produção de decisões coletivamente vinculantes e a estabilização de expectativas normativas) e possuem códigos distintos (governo-oposição e lícito-ilícito). Não obstante, os seus procedimentos se encontram vinculados numa dinâmica circular de checks and balances. Através da repartição orgânica de competências e do controle recíproco estabelecidos pela Constituição, o Estado Democrático de Direito é instituído como modelo de horizontalidade orgânica e circularidade procedimental ${ }^{84}$.

O sistema político disponibiliza a sua complexidade para a construção da complexidade do sistema jurídico, e vice-versa. Além disso, o Estado Democrático de Direito se caracteriza pela troca de prestações entre os dois sistemas. Segundo Luhmann, uma prestação se refere à relação de um sistema funcional com um ou mais sistemas funcionais, enquanto a função se refere à relação de um sistema funcional com a sociedade considerada em sua totalidade ${ }^{85}$. Cada sistema funcional possui apenas uma função, embora possa efetuar várias prestações. Como as operações dos sistemas são funcionalmente orientadas, as prestações só podem ocorrer a partir do desempenho da função, e não em seu detrimento.

Enquanto a função é desempenhada para a sociedade como um todo, uma prestação representa uma conseqüência estabilizada que a operação de um sistema funcional produz sobre outros sistemas, sejam eles sistemas funcionais, organizações ou interações. Cada sistema funcional desempenha uma única e exclusiva função na sociedade, englobando todas as comunicações a ela relacionadas. Todas as comunicações sobre o que é lícito ou ilícito são comunicações do sistema jurídico, por exemplo. Isso faz com que os chamados equivalentes funcionais, em sentido estrito, existam apenas no âmbito das prestações, e não no âmbito das funções: trata-se, portanto, de equivalentes "prestacionais ${ }^{86 "}$.

\footnotetext{
${ }^{84}$ Marcelo NEVES, Entre Têmis e Leviatã: uma relação difícil, p. 153.

${ }^{85}$ Niklas LUHMANN, Law as a Social System, p. 167.

${ }^{86}$ Os estudiosos do pluralismo jurídico, portanto, devem ter essa distinção em mente. Por todos, o famoso estudo de Boaventura de Sousa SANTOS: "Notas sobre a História Jurídico-Social de Pasárgada". In: Cláudio SOUTO e Joaquim FALCÃO (orgs.), Sociologia e Direito. São Paulo: Pioneira, 1999. Infelizmente, não é possível aprofundar essa discussão aqui.
} 
Vejamos o exemplo do direito: as prestações jurídicas mais discutidas na literatura jurídica são o controle de comportamentos e a resolução de conflitos ${ }^{87}$. Não é difícil notar que nem todo mecanismo de controle comportamental é jurídico: resultados semelhantes podem ser obtidos através da religião, do dinheiro ou mesmo do poder político. O mesmo é válido para a resolução de conflitos: a própria política constitui um sistema amplamente especializado na resolução de conflitos coletivos, e cada vez mais são discutidas alternativas à resolução judicial de conflitos, como a mediação e conciliação. Esses mecanismos, quando não fazem referência ao código lícito-ilícito e às leis existentes, não são parte do sistema jurídico.

Sempre que a expressão "equivalentes funcionais" for utilizada no presente trabalho, estaremos fazendo referência a processos que produzem resultados semelhantes. A teoria dos sistemas de Luhmann é um método extremamente frutífero para a realização de tais comparações. O uso do termo, portanto, será feito em sentido amplo. Em momento nenhum afirmamos que um sistema funcional desempenha a mesma função desempenhada por outro sistema funcional, pois a existência de sistemas funcionais diferenciados se baseia justamente no fato de cada sistema ter se especializado na resolução de um problema específico ${ }^{88}$.

Feitas as seguintes considerações sobre a diferença entre função e prestação, cumpre agora analisar quais são as principais prestações que o sistema jurídico presta ao sistema político no Estado Democrático de Direito, e vice-versa. Como dito anteriormente, o sistema político cria e mantém condições que possibilitam a estruturação organizacional do sistema jurídico e a obrigatoriedade das decisões judiciais. Ao mesmo tempo, o sistema jurídico possibilita uma estruturação mais complexa e previsível da administração pública, ao administrar a diferença entre o que é lícito e o que é ilícito.

O sistema jurídico estabiliza expectativas normativas em relação ao comportamento das organizações políticas, ou seja, sempre que houver suspeitas de que uma organização política agiu de forma contrária à lei, é possível acionar o

\footnotetext{
${ }^{87}$ Niklas LUHMANN, Law as a Social System, p. 168.

${ }^{88}$ A emergência dos sistemas funcionais, nesse contexto, se dá justamente a partir do momento em que uma determinada solução para um problema específico se repete a ponto de produzir a estabilização de uma estrutura. Jorge Galindo MONTEAGUDO, "La Teoría Sistémica de Niklas Luhmann: alcances e limites". In Niklas LUHMANN, La Sociedad de la Sociedad. Ciudad de México: Herder, 2007, p. XXXVIII. Esse tema será discutido mais detalhamente no terceiro capítulo.
} 
procedimento judicial para que essa suspeita seja institucionalmente confirmada ou descartada. Além de procurar conformar o comportamento dos atores políticos ao direito, o sistema jurídico também procura solucionar conflitos que são inicialmente políticos e que não foram solucionados nas instâncias representativas e deliberativas do sistema político ${ }^{89}$.

Esse último fenômeno tem se manifestado com intensidade nas últimas décadas, e tem sido amplamente discutido sob o rótulo de politização do judiciário (e conseqüente judicialização da política). A politização do judiciário não significa de forma alguma que o direito passe a atuar fora dos seus limites, "invadindo" o domínio da política, pois o conflito é reconstruído a partir de critérios jurídicos ${ }^{90}$. A politização do judiciário indica somente que cada vez mais os tribunais estão sendo utilizados para discutir questões que antes estavam circunscritas ao âmbito da política, ou mesmo como forma de descarregar a política de conflitos que ela não consegue solucionar.

A politização do judiciário (ou judicialização da política) ocasiona novas irritações entre a política e o direito, nem sempre interpretadas de forma positiva por ambos os sistemas. Surgem acusações de que o direito "despolitiza" os conflitos sociais ao tratá-los como embates entre sujeitos abstratos detentores de direitos subjetivos ${ }^{91}$. Da mesma forma, os tribunais são acusados de interferir negativamente na atividade do poder executivo, principalmente no caso das políticas públicas e da política orçamentária, tratando-as sob o ponto de vista de direitos subjetivos plenamente realizáveis, independentemente dos custos necessários para a sua realização ${ }^{92}$.

Ao fracionar e intermediar conflitos de natureza política, descarregando a política de conflitos que ela não consegue resolver, o procedimento judicial contribui

\footnotetext{
${ }^{89}$ Pietro Barcellona, a partir da tradição marxista, afirma: "la juridificación de los problemas de la vida es un expediente táctico, una estrategia oportunista que se realiza mediante la transferencia de los problemas políticos (no resolubles en el terreno del enfrentamiento ni en el terreno político-legislativo) al terreno más conveniente y controlable de la jurisdicción (de la individualización del conflito). La jurisdicción es uno de los ámbitos a través de los cuales el sistema social distribuye y regula el potencial del conflito político existente en la sociedad y lo neutraliza mediante la canalización judicial: así, el conflicto político se convierte en el conflicto individual y puede ser resuelto sobre la base de una regla y de un procedimiento". El Individualismo Propietario. Tradução de Jesús Ernesto García Rodríguez. Madrid: Trotta, 1996, p. 77.

90 "It is important to note that law does not necessarily solve the original conflicts but only those that it can reconstruct on its own terms”. Niklas LUHMANN, Law as a Social System, p. 169.

${ }_{91}$ Alysson Leandro MASCARO, Crítica da Legalidade e do Direito Brasileiro. São Paulo: Quartier Latin, 2008.

${ }^{92}$ É o caso do debate recente sobre a judicialização da política de saúde no Brasil. Fabíola Sulpino VIEIRA e Paola ZUCCHI, "Distorções Causadas pelas Ações Judiciais à Política de Medicamentos no Brasil”. Revista de Saúde Pública / Journal of Public Health, v. 41, 2007, pp. 214-222.
} 
para a manutenção da paz e da ordem social e, portanto, para a legitimação do sistema político. Os tribunais possuem ao seu favor o fato de não precisarem atuar como se fossem organizações do poder legislativo ou do poder executivo. Eles não dependem da existência de consenso ou apoio político para decidir - e nem ao menos da existência de consenso jurisprudencial e doutrinário. Eles podem - e devem - decidir mesmo quando os mais eminentes juristas e tribunais discordam profundamente sobre uma determinada questão, e as leis existentes não fornecem uma resposta minimamente clara.

Os tribunais também não precisam realizar as inversões de recursos necessárias ao cumprimento de uma decisão. Um tribunal pode ordenar a construção de uma escola, mas não será responsável por destinar recursos para a obra e por contratar e treinar os professores, etc. Para o tribunal, basta afirmar que uma determinada expectativa normativa continua válida mesmo que ela tenha sido desapontada por um comportamento desviante. Ao seu desfavor, no entanto, os tribunais possuem o fato de serem obrigados a decidir: a recusa em tomar uma decisão implica denegação de justiça (non liquet ${ }^{93}$ ). Já as organizações políticas, na maioria das vezes, podem decidir somente quando existem condições políticas ou orçamentárias adequadas.

O sistema jurídico, portanto, oferece condições que contribuem para a legitimação do sistema político. O sistema político, por sua vez, ao garantir os pressupostos democráticos de produção do direito e o uso do poder de modo a dificultar e desencorajar reações que negam ou ignoram as decisões judiciais, contribui para a legitimação do sistema jurídico ${ }^{94}$. Um direito totalmente arredio ao controle democrático teria muito mais dificuldade para ser socialmente aceito (Habermas tem toda a razão em insistir nessa questão).

Através da Constituição - que é um elemento comum ao direito e à política - por fim, é oferecida uma solução jurídica para o problema da auto-referência do sistema político e uma solução política para o problema da auto-referência do sistema jurídico ${ }^{95}$. O poder democrático é o poder exercido conforme o direito, e o direito válido é um direito produzido democraticamente. Cada sistema observa a Constituição de uma

\footnotetext{
${ }^{93}$ Niklas LUHMANN, Law as a Social System, pp. 274-304.

94 “[...] law must have a sufficient chance of implementation because otherwise one would resign oneself to accepting the facts and learn from them. Law cannot rely only on reassuring those who have been disappointed in their expectations of law that their expectations were right. Something has to be done to achieve either a real or at least some compensatory enforcement of the law". Niklas LUHMANN, Law as a Social System, p. 137.

${ }^{95}$ Niklas LUHMANN, Law as a Social System, p. 410.
} 
maneira: para o sistema jurídico, ela é a lei suprema. Para o sistema político, ela é um instrumento político, tanto da política instrumental quanto da política simbólica (de caráter político-legitimador). ${ }^{96}$

Em nenhum desses casos de troca de prestações legitimatórias - o sistema jurídico contribuindo para a legitimação do sistema político e o sistema político contribuindo para a legitimação do sistema jurídico - trata-se de uma "legitimação a partir de fora" (heterolegitimação). Cada sistema cria e administra condições que facilitam com que o outro se autolegitime, ou seja, cada sistema se aproveita de condições geradas pelo outro para se autolegitimar ${ }^{97}$. Aos olhos da tradição jusfilosófica e sociológica e aos olhos do público, no entanto, trata-se da legitimação "em bloco" de ambos os sistemas: a legitimação do Estado Democrático de Direito. No próximo capítulo, veremos como isso ocorre.

\footnotetext{
${ }^{96}$ Niklas LUHMANN, Law as a Social System, p. 410.

97 Esse modelo mantém-se alinhado à opinião de Luhmann e torna desnecessária a distinção entre autolegitimação e heterolegitimação, feita por Marcelo Neves (Entre Têmis e Leviatã: uma relação difícil, p. 148). Essa distinção busca compatibilizar a teoria dos sistemas de Luhmann com a teoria do discurso de Habermas, que localiza a esfera pública no exterior do sistema político. Como afirmado anteriormente, também contornamos a necessidade dessa distinção posicionando a esfera pública no interior do sistema político, conforme a proposta de Stichweh.
} 


\section{A LEGITIMAÇÃO DAS DECISÕES DO ESTADO DEMOCRÁTICO DE DIREITO.}

Those interested in understanding how to mantain the social system have been concerned with identifying the conditions that promote legitimacy; those seeking social change have sought to understand how to undermine it.

Tom R. Tyler

No capítulo anterior, foi apresentado o conceito de política e de direito que norteará o presente trabalho. O Estado Democrático de Direito, concebido pela tradição política e jurídica como uma unidade, foi apresentado como o resultado da diferenciação de dois sistemas funcionais: o sistema jurídico e o sistema político. $\mathrm{O}$ Estado Democrático de Direito pressupõe tanto a autonomia operacional da política quanto a autonomia operacional do direito (principalmente em relação à política). Somente um sistema jurídico autônomo é capaz de administrar juridicamente a diferença entre o que é lícito e o que é ilícito, de modo que o poder político seja exercido em conformidade com o direito - aquilo que a tradição denominou rule of law.

Os procedimentos do Estado Democrático de Direito (eleitoral, legislativo, administrativo e judicial) foram descritos como procedimentos juridicamente 
estruturados que especificam conflitos socialmente difusos e os intermedeiam através da produção de uma decisão. No presente capítulo, analisaremos como eles contribuem para a legitimação do Estado Democrático de Direito. Para isso, o capítulo será iniciado com uma explicação mais detalhada sobre o significado da expressão "procedimentos juridicamente estruturados".

O sistema político e o sistema jurídico possuem como centro organizações que produzem um número massivo de decisões (a administração pública e os tribunais, respectivamente). Enquanto os tribunais são forçados a decidir (pois a recusa em tomar uma decisão equivale a uma denegação de justiça ou non liquet), a administração pública possui uma liberdade decisória maior, podendo decidir somente quando existem condições políticas apropriadas, como o apoio parlamentar ou o apoio do público.

Os procedimentos são aquisições evolutivas que são conseqüência dessa necessidade de decidir e, ao mesmo tempo, uma maneira de administrar a sua reprodução. Eles são conjuntos de eventos voltados à produção de uma decisão. São regidos por premissas decisórias (normas procedimentais) e especificam papéis sociais (eleitor, administrador, parlamentar, público etc.). As premissas decisórias definem quem deve decidir, quando deve haver decisão e o quê deve ser decidido - ou seja, delimitam a decisão na dimensão social, temporal e material. Os procedimentos buscam diminuir a arbitrariedade das decisões estatais, isto é, o seu grau de incerteza e de ambigüidade.

Pelo menos desde as contribuições de Weber para a sociologia, é sabido que o poder político passou por um intenso processo de juridificação entre o século XVIII e o século XX. A juridificação - que nada mais é que a estruturação das organizações estatais e dos seus procedimentos por normas jurídicas - tornou previsível o exercício do poder e criou condições para um massivo aumento de complexidade nos "recémnascidos" domínios funcionais da sociedade. É notória a afirmação de Weber de que o poder político previsível possibilitou, dentre outras coisas, o cálculo racional tão caro à empresa capitalista.

A existência dessa quota de previsibilidade permitiu à empresa capitalista assumir riscos que antes não poderiam ser assumidos. Se não houvesse relações estáveis entre as nações, os riscos do comércio internacional não poderiam ser plenamente 
assumidos, por exemplo. A segurança - no sentido um grau adequado de previsibilidade - é um mecanismo necessário para que mais insegurança possa ser gerada e assumida. ${ }^{98}$ Quanto maior o grau de insegurança que a sociedade pode suportar sem entrar em colapso, maior é a sua complexidade: a evolução da sociedade é uma história de ampliação da insegurança ${ }^{99}$.

A juridificação do processo decisório do Estado Democrático de Direito produz segurança na sociedade a partir do momento em que são generalizadas expectativas de que decisões ilegais não ocorrerão com a mesma freqüência que as decisões consideradas legais, e que é possível contar com a atuação dos tribunais quando o poder político exceder os limites da legalidade. As normas jurídicas são estruturas da sociedade e devem garantir que as possibilidades excluídas - no caso, a ilegalidade não sejam reintroduzidas com freqüência. Somente dessa forma elas cumprem a sua função enquanto estrutura ${ }^{100}$.

Segundo Luhmann, as normas jurídicas são expectativas de comportamento que orientam as interações ${ }^{101}$. Enquanto expectativas normativas, elas não se adaptam aos fatos quando os fatos as contrariam: o ônus da adaptação recai sobre aquele que agiu de modo contrário à expectativa normativa. Nem todas as expectativas normativas existentes na sociedade são normas jurídicas. Em cada local existem costumes, convenções e normas sociais que se relacionam de maneira específica com as normas jurídicas, ora reforçando-as, ora prejudicando a sua eficácia (basta observar o caso dos códigos de conduta das organizações criminosas). Cabe à pesquisa sociológica identificar essa relação.

As interações relevantes para os procedimentos do Estado Democrático de Direito podem ser classificadas em: (i) interações que ocorrem no interior dos procedimentos e (ii) interações que ocorrem anteriormente ou paralelamente aos procedimentos, mas influenciam a decisão produzida (é o caso do juiz que uma semana

\footnotetext{
${ }^{98}$ Se desejássemos observar como essa relação ocorre no interior do sistema econômico, poderíamos tomar como exemplo o caso de uma pequena empresa que assume o risco de celebrar um contrato futuro em moeda estrangeira porque tem a certeza de poder se livrar do risco da flutuação cambial através de um contrato de hedge. Parte considerável do dinamismo e da complexidade do sistema econômico provém da sua incrível capacidade de prover a segurança necessária para que novas formas de insegurança sejam assumidas.

${ }^{99}$ Niklas LUHMANN, Social Systems, pp. 309-310.

${ }^{100}$ Niklas LUHMANN, Social Systems, p. 284.

${ }^{101}$ Niklas LUHMANN, Sociologia do Direito, Volume I, pp. 53-66.
} 
antes do julgamento recebe a visita de uma das partes, que lhe oferece dinheiro). As expectativas não jurídicas que orientam essas interações podem: (i) constituir um reforço (enforcement) das premissas procedimentais, (ii) ser irrelevantes para as premissas procedimentais ou (iii) constituir um estímulo à fraude das premissas procedimentais e, portanto, um indicador dos limites de eficácia do direito.

No primeiro caso, trata-se daquilo que Robert E. Scott chama de sanções informais, ou sanções de segunda ordem: aqueles que desobedecem às normas jurídicas são punidos com sanções tais como a indignação e o desprezo dos seus pares. ${ }^{102}$ No último caso, trata-se da existência de estruturas sociais contraditórias: de um lado, as normas jurídicas que estabelecem premissas decisórias. Do outro lado, as estruturas socialmente difusas de incentivo a comportamentos ilegais e que constituem empecilhos à eficácia das normas jurídicas e, conseqüentemente, empecilhos ao desempenho do sistema político e do sistema jurídico.

\subsection{A Legitimidade como Fórmula de Contingência do Sistema Político.}

Como exposto no capítulo anterior, o Estado Democrático de Direito é o centro tanto do sistema político - sob a forma de administração pública - quanto do sistema jurídico - sob a forma tribunais. O sistema político é permeado por comunicações que circulam na esfera pública, instância onde vários atores buscam influenciar a tomada das decisões coletivamente vinculantes. A esfera pública desempenha para o sistema político um papel análogo ao que o mercado desempenha para o sistema econômico. Assim como os atores econômicos observam o mercado para se colocar a par do estado de coisas do sistema, em busca de informação que possa se converter em lucro, os

\footnotetext{
${ }^{102}$ Scott cita o exemplo de um casal de caminhantes que adentra uma trilha com o seu cão, infringindo a lei que proíbe a entrada de cães na trilha. O casal é então repreendido pelos vizinhos. $\mathrm{O}$ enforcement da lei, nesse caso, se deu independentemente da atividade fiscalizadora do Estado. Os insights do autor são reveladores, embora devam ser discutidos no plano das expectativas sociais, e não no plano das preferências internas dos indivíduos. Robert E. SCOTT, "The Limits of Behavorial Theories of Law and Social Norms". Virginia Law Review, n 86, 2000, pp. 1603-1647.
} 
diversos atores políticos observam a esfera pública em busca de resposta para a seguinte questão: o que pode ser politicamente realizado?

No sistema econômico, a medida do realizável é dada pela escassez: as alocações possíveis de recursos são limitadas pela quantidade existente de recursos ${ }^{103}$. No sistema político, a delimitação do realizável também ocorre no interior do próprio sistema: o leque de decisões politicamente possíveis é dado por aquilo que o público está disposto a aceitar. Contrariar a opinião pública é um risco político a ser assumido. Na política, entretanto, a delimitação do possível é realizada com uma acuidade muito menor do que no caso da economia. Os recursos econômicos são facilmente quantificáveis. A opinião pública, não.

Os recursos econômicos são expressos ou conversíveis em valores numéricos. Já as comunicações relevantes para a legitimação do sistema político manifestam-se de duas formas, conforme percebido por David Easton: enquanto apoio específico (specific support) e, principalmente, enquanto apoio difuso (diffuse support). ${ }^{104} \mathrm{O}$ apoio específico é o apoio dado a decisões individualmente consideradas ou aos governantes, e o apoio difuso é uma reserva de atitudes favoráveis ou de boa vontade, que torna as decisões políticas mais passíveis de aceitação, mesmo em caso de discordância quanto ao seu conteúdo, e constitui uma variável difícil de aferir empiricamente ${ }^{105}$.

Assim como os agentes econômicos podem tomar decisões que desconsideram a escassez, as organizações estatais podem tomar decisões que desconsideram a margem dentro da qual o público está disposto a aceitar (ou podem deixar de agir quando o público não está disposto a tolerar a omissão). Na economia, os atores que agem em desconsideração ao estado de coisas do sistema (não só a escassez) são sumariamente eliminados do "jogo econômico". Na economia de mercado, não há espaço para agentes irracionais e incapazes de aprender com os seus erros. Já no caso da política, as coisas ocorrem de maneira bem mais complexa.

Em primeiro lugar, a opinião pública não constitui um bloco consensual de valores e interesses, mas um plexo de valores e interesses contraditórios e instáveis. Isso

${ }^{103}$ Niklas LUHMANN, Die Wirtschaft der Gesellschaft. Frankfurt am Main: Suhrkamp, 1988, pp. 177229.

${ }^{104}$ David EASTON, "A Re-Assessment of the Concept of Political Support", British Journal of Political Science, Vol. 5, No. 4 (Oct., 1975), pp. 435-457.

${ }^{105}$ David EASTON, "A Re-Assessment of the Concept of Political Support", p. 444. 
torna difícil calcular com exatidão as conseqüências políticas de uma decisão e cria situações nas quais as organizações estatais se vêem diante da necessidade de produzir decisões que gerarão discordâncias qualquer que seja o seu conteúdo. Em segundo lugar, as consequiências de uma decisão equivocada produzida por um agente estatal são bem menos danosas do que as consequiências de uma decisão equivocada produzida por um agente econômico. O Estado não é "eliminado do jogo político" por produzir decisões politicamente desastrosas, e dispõe de um grande potencial de coação física, a ser utilizado em caso de ameaças à ordem.

O Estado está sujeito a uma pressão adaptativa muito menor do que os agentes econômicos, que são pressionados a adotar uma administração eficiente e flexível e a adquirir uma enorme quantidade de informação estratégica. Somente dessa maneira eles podem "sobreviver" em um ambiente extremamente competitivo e dinâmico. Já o Estado não se encontra propriamente numa relação de concorrência com outros Estados, e a sua estrutura burocrática demanda muito mais tempo para ser alterada. As organizações estatais, em razão dessas características, são muito menos aptas - e dispostas - ao aprendizado do que as organizações econômicas.

Apesar de serem menos dinâmicas do que as organizações econômicas, as organizações estatais operam num ambiente mais seguro. O Estado conta com uma considerável margem de indiferença dos cidadãos em relação às suas decisões, fruto de custos de informação ou do mero desinteresse ${ }^{106}$. E mesmo que os cidadãos estejam extremamente insatisfeitos com as organizações estatais, a sua insatisfação só adquire relevância política caso sejam vencidos os obstáculos de mobilização e de organização da ação coletiva. E mesmo que o público consiga se mobilizar e se organizar, os seus objetivos ainda podem esbarrar no aparato coercitivo do Estado.

Por essa razão, o Estado Democrático de Direito é dotado de um amplo campo de manobra (Spielraum) para a tomada de decisões que desconsideram ou avaliam erroneamente a opinião pública. Mas a sua principal estratégia para manter a sua capacidade de produzir decisões coletivamente vinculantes não consiste em confiar no seu potencial coercitivo ou nas dificuldades de mobilização e organização dos cidadãos,

${ }^{106}$ Segundo Easton, o desinteresse pode ser um indicador de confiança (trust) nas organizações estatais, que é um dos componentes do apoio difuso. A confiança é a expectativa de que as organizações estatais produzirão decisões favoráveis mesmo quando submetidas a pequena supervisão ou escrutínio. "A ReAssessment of the Concept of Political Support", pp. 447-448. 
mas na criação de procedimentos democráticos que permitem uma influência controlada do público sobre as decisões políticas e jurídicas. Um "chamado à legitimidade" ("call to legitimacy") é muito mais efetivo do que um "chamado às armas" ("call to arms").

A natureza temporal, material e socialmente instável da legitimidade - pelo menos quando a comparamos à escassez - não a impede de desempenhar o papel de fórmula de contingência do sistema político. Uma fórmula de contingência possui a função de transformar complexidade indeterminada em complexidade determinada, de modo que nem tudo seja possível para o sistema ${ }^{107}$. Cada sistema funcional possui a sua própria fórmula de contingência: a escassez no caso do sistema econômico, a legitimidade no caso do sistema político, a justiça no caso do sistema jurídico e a capacidade de aprendizado no sistema educacional, etc.

A escassez (tanto de bens quanto de dinheiro) indica que nem tudo pode ser produzido ou adquirido ${ }^{108}$. A capacidade de aprendizado indica que nem tudo pode ser ensinado ou aprendido ${ }^{109}$. A justiça indica que existe preocupação com a congruência das decisões jurídicas (tratar igualmente os casos iguais e desigualmente os casos desiguais) e com a adequada complexidade do sistema jurídico ${ }^{110}$. A legitimidade, por sua vez, indica que nem tudo pode ser decidido politicamente, mesmo quando possível economicamente ou juridicamente.

A legitimidade não advém de estados mentais formados monologicamente, como supõe o individualismo metodológico e o psicologismo, mas das comunicações que têm lugar na esfera pública. Nas palavras de Robert Grafstein, "a política ocorre

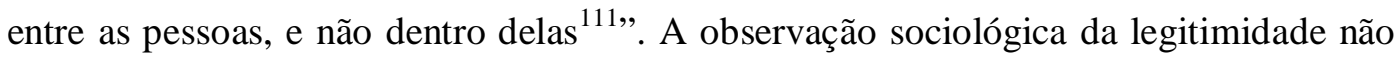
busca observar estados mentais, mas resultados agregados das comunicações travadas na esfera pública e ações que podem ser compreendidas como indicadoras da

\footnotetext{
107 Javier TORRES NAFARRATE, Luhmann: La Política como Sistema, p. 168.

${ }^{108}$ Se não houvesse escassez, não haveria a economia, pois um bem só adquire valor econômico a partir da sua escassez. A escassez é condição necessária (mas não suficiente) do valor.

${ }^{109}$ Por essa razão, a pedagogia se destina a estudar o desenvolvimento cognitivo humano e a sugerir o que deve ser ensinado em cada idade e como isso deve ser feito.

${ }^{110}$ Niklas LUHMANN, Law as a Social System, pp. 211-229.

111 " [...] the psychological conception of politics is not condemned simply because it appeals to unobservable and inaccessible entities. There is nothing illicit about inferring internal states from behavior. Rather, the irreducibly public character of behavior which is counted political renders the specific nature of such internal states irrelevant. [...] Politics occurs among people, not within them". Robert GRAFSTEIN, “The Legitimacy of Political Institutions”. Polity, Vol. 14, No. 1 (Autumn, 1981), p. 55.
} 
legitimidade ou a ilegitimidade. Trata-se, portanto, de uma proposta teórica com pretensões empíricas.

Embora a idéia de legitimidade como fórmula de contingência seja valiosa, o conceito de legitimidade oferecido por Luhmann na obra "Die Politik der Gesellschaft" é demasiado obscuro (talvez pelo fato de tratar-se de uma obra incompleta, publicada post-mortem). No capítulo intitulado "Diferenciação e Fechamento Operativo do Sistema Político", Luhmann define a legitimidade como condição de possibilidade da tematização política ou, mais especificamente, como representação por meio da referência a valores daquilo que pode ser tematizado politicamente ${ }^{112}$.

De acordo com Luhmann, as preferências legítimas são aquelas que podem ser apresentadas e reivindicadas publicamente ${ }^{113}$. As preferências ilegítimas não podem ser apresentadas e reivindicadas publicamente porque são conteúdos inaceitáveis aos olhos do público. O público não só discorda delas como considera a sua presença na esfera pública inaceitável. Segundo Anna Marie Drake, a legitimidade é pré-condição para que a preferência adentre o debate democrático. As preferências ilegítimas são consideradas não apenas moralmente incorretas, mas indignas de consideração moral ${ }^{114}$. Não é preciso citar exemplos $a b$ absurdo, como a legalização da pedofilia (embora nos Estados Unidos existam aqueles que defendem publicamente essa proposta!). Basta observar como os grupos com preferências radicais se abstêm de expressá-las publicamente para obter o apoio do público para as suas preferências menos polêmicas.

O fato de as condições de possibilidade da tematização política serem fornecidas pelos conteúdos já tematizados politicamente, ou seja, o fato de as condições de possibilidade das comunicações políticas serem dadas pelas próprias comunicações políticas, indica que o sistema político é um sistema auto-referencial, que se reproduz a partir do sentido gerado em seu próprio interior. Como o sistema político possui um

\footnotetext{
112 "Kontingenzformeln benennen "Bedingungen der Möglichkeit", hier also Bedingungen politischer Thematisierung in einer Weise, die ihrerseits nicht mehr auf Bedingungen ihrer Möglichkeit hin aufgelöst werden kann". "As fórmulas de contingência designam "condições de possibilidade", aqui também condições de tematização política de uma maneira que não pode mais ser resolvida nas condições de sua possibilidade" (tradução livre). Niklas LUHMANN, Die Politik der Gesellschaft, p. 120.

${ }^{113}$ Niklas LUHMANN, Die Politik der Gesellschaft, p. 122.

${ }^{114}$ Drake trabalha com a distinção entre a correção moral (moral correctness) e a respeitabilidade moral (moral respectability) de um argumento (esta última, critério para a "inclusão no grupo deliberativo"). Anna Marie DRAKE, Constructing Democratic Space: inclusion, efficacy and protest in deliberative democratic theory. Thesis submitted to the Department of Political Studies in conformity with the requirements for the degree of Doctor of Philosophy. Queen's University: Kingston, Canada, 2008, p. 96.
} 
centro que produz um grande número de decisões, também é preciso questionar qual a relevância da legitimidade para as decisões coletivamente vinculantes da administração pública. A resposta para essa pergunta é a seguinte: os resultados agregados produzidos na esfera pública delimitam fronteiras decisórias que a administração pública não pode ultrapassar impunemente.

A legitimidade não representa somente a condição de possibilidade para a seleção de comunicações políticas (sob a forma de condição de possibilidade de tematização política). Sob o ponto de vista da administração pública, ela representa a condição de possibilidade (política) das decisões coletivamente vinculantes. Aquilo que não pode ser tematizado politicamente tampouco pode ser politicamente decidido. Ao contrário de Luhmann, que enfatiza o campo extradecisório da tematização política, o presente trabalho opta por enfatizar o campo da delimitação de alternativas decisórias, condição necessária para que a legitimidade seja útil para a compreensão do processo de legitimação do Estado Democrático de Direito.

\subsection{A Legitimidade Enquanto Aceitação e a Legitimação pelo Procedimento.}

Grande parte da história do Estado Democrático de Direito pode ser recontada através do crescimento quantitativo e qualitativo da demanda por decisões estatais e do crescimento quantitativo e qualitativo da capacidade do Estado de produzi-las ${ }^{115}$. O Estado Democrático de Direito tem sido ininterruptamente demandado a produzir

decisões sobre os mais variados temas. À luz de uma teoria da sociedade baseada na comunicação, no entanto, o que significa dizer que uma "decisão foi tomada"? Qual a "natureza" daquilo que chamamos de decisão?

\footnotetext{
${ }^{115}$ Claus OFFE, Capitalismo Desorganizado: transformações contemporâneas do trabalho e da política. São Paulo: Brasiliense, 1994, p. 10 e ss.
} 
Como qualquer operação social, uma decisão é uma comunicação e, como toda comunicação, comunica algo (uma informação). ${ }^{116}$ No caso de uma decisão política ou jurídica, esse algo comunicado pode ser um aumento de impostos, a legalização do aborto, o início da construção de uma rodovia, a inconstitucionalidade de uma lei, etc. $\mathrm{O}$ fato das decisões políticas e jurídicas serem decisões coletivamente vinculantes implica que existe uma expectativa disseminada na sociedade de que essas decisões sejam legítimas, e não o resultado arbitrário de um processo decisório imprevisível e desorganizado.

Como qualquer comunicação, uma decisão pode ser aceita ou rejeitada. $\mathrm{O}$ seu conteúdo pode ser alvo tanto de um "sim" quanto de um "não". No caso das decisões estatais, que são comunicações dirigidas a uma coletividade, impõe-se a necessidade de que, na maioria das vezes, a maioria das pessoas responda com um "sim", ou seja, aceite a decisão. Como vimos no capítulo anterior, o sistema político possui um mecanismo capaz de tornar a aceitação das suas decisões mais provável do que a sua rejeição. Esse mecanismo é o poder, meio de comunicação simbolicamente generalizado que circula no interior do sistema. O poder não pode eliminar o risco de rejeição, mas pode reduzi-lo drasticamente.

O poder possibilita que o sistema político e o sistema jurídico se reproduzam mesmo na ausência de um consenso abrangente em torno do conteúdo das suas decisões. Isso ocorre sem que o poder precise demonstrar continuamente o que é capaz de realizar instrumentalmente: as democracias se reproduzem sem a necessidade de utilização dos suplícios descritos por Foucault em Vigiar e Punir ${ }^{117}$ - e hoje em dia tais métodos seriam considerados inaceitáveis. Esse resultado foi alcançado principalmente em função da democratização, da juridificação e da burocratização do processo decisório do Estado, ou seja, através da criação e da manutenção de procedimentos democráticos para a tomada de decisões.

\footnotetext{
116 Segundo Luhmann, uma decisão não é tomada e depois comunicada: a decisão é comunicação. Ela constitui um tipo específico de comunicação. Enquanto uma comunicação comum comunica apenas o conteúdo selecionado (como "está chovendo"), uma decisão também comunica a existência de alternativas que poderiam ter sido selecionadas no lugar da alternativa escolhida, ou seja, ela comunica a sua própria contingência, de forma explícita ou implícita ("eu vou construir um hospital no local $X$, e não um parque"). David SEIDL, “The Basic Concepts of Luhmann's Theory of Social Systems”, p. 37. Niklas LUHMANN, Organisation und Entscheidung. Opladen/Wiesbaden: Westdeutscher Verlag, 2000.

${ }^{117}$ Michel FOUCAULT, Vigiar e Punir. Petrópolis: Vozes, 1971.
} 
No caso da política e do direito, dizer que uma decisão foi aceita não significa dizer que houve concordância com o seu conteúdo (seja um consenso ou uma anuência a partir de um cálculo de custo-benefício). A reprodução do Estado Democrático de Direito não pode depender do cumprimento de um objetivo tão ambicioso ${ }^{118}$. Além disso, para a política e para o direito, os motivos que levam alguém a obedecer a uma decisão são irrelevantes, como já afirmou $\mathrm{Kant}^{119}$. Para nós, esses motivos são até mesmo imperscrutáveis, pois são estados mentais opacos de cada indivíduo, nem sempre exteriorizados através da comunicação.

Para a política e para o direito, interessa apenas a correspondência entre o comportamento prescrito e o comportamento observado, ou seja, a obediência. A decisão deve ser aceita como premissa de comportamento em qualquer circunstância, mesmo quando se discorda do seu conteúdo. Os eventuais desapontamentos devem ser manifestados dentro dos limites do procedimento que produziu a decisão ou dentro dos limites tolerados pelo Estado Democrático de Direito. No caso em que a decisão não prescreve nenhum comportamento comissivo específico, espera-se somente o comportamento omissivo de respeito aos limites de exercício do dissenso.

A aceitação de uma decisão, portanto, não deve ser compreendida como consenso em torno do seu conteúdo, mas como renúncia a comportamentos que discordam da decisão fora dos limites estabelecidos pelo direito, dentro de certa margem de tolerância. A legitimidade, por sua vez, numa perspectiva sociológica, pode ser compreendida como uma "disposição generalizada para aceitar decisões de conteúdo ainda indeterminado, dentro de margens certas de tolerância ${ }^{120 "}$. É preciso assegurar que as decisões obrigatórias sejam consideradas premissas de comportamento sem que seja necessário especificar com antecedência quais decisões concretas serão tomadas.

Esse conceito se aproxima do conceito de legitimidade racional-legal de Weber, pois se baseia no fato da decisão ter sido tomada em conformidade com a lei, tanto

\footnotetext{
${ }^{118}$ Niklas LUHMANN, Legitimation durch Verfahren, p. 32.

119 Immanuel KANT, Introducción a la Teoría del Derecho. Madrid: Centro de Estudios Constitucionales, 1978, p. 82 e ss. No mesmo sentido, Habermas: "o direito moderno não imputa nenhum motivo ético à obediência dos sujeitos de direito; ele protege as suas inclinações privadas dentro dos limites sancionados. Não se punem as más intenções, mas somente as ações que se desviam das normas (o que pressupõe as categorias de responsabilidade e culpa)" (tradução livre). Theorie des Kommunikativen Handelns. Band 1:Handlungsrationalität und gesellschaftliche Rationalisierung, p. 352.

${ }^{120}$ Niklas LUHMANN, Legitimation durch Verfahren, p. 28 (tradução livre).
} 
formal quanto materialmente ${ }^{121}$. Ele pressupõe a diferença entre premissas decisórias e decisão ou, na terminologia de Hart, entre regras secundárias e regras primárias ${ }^{122}$. As regras secundárias são regras sobre como as regras primárias devem ser criadas. São decisões sobre como se deve decidir ${ }^{123}$. As regras secundárias existem somente no Estado de Direito: o direito socialmente difuso das comunidades pré-modernas não possuía regras secundárias (regras procedimentais), mas somente regras primárias (regras de conduta).

As regras secundárias são mecanismos reflexivos imprescindíveis para que o Estado Democrático de Direito mantenha um alto grau de complexidade e conduza o seu processo de legitimação ${ }^{124}$. A construção de mecanismos reflexivos em seu processo decisório torna muito mais fácil a absorção de variações nos comportamentos dos indivíduos ${ }^{125}$. Somente a partir da diferença entre regras secundárias e regras primárias é possível existir a diferença entre concordar com as premissas decisórias e concordar com a decisão. É possível aceitar as premissas decisórias e ao mesmo tempo discordar do conteúdo da decisão. Da mesma forma, é possível concordar com o conteúdo da decisão sem desejar que as suas premissas decisórias sejam utilizadas para decisões posteriores.

Mesmo quando alguém discorda da decisão, a sua aceitação torna-se mais provável quando ela é tomada com base em premissas decisórias consideradas imparciais e justas. A existência de premissas decisórias descarrega o Estado parcialmente da necessidade de buscar uma legitimação conteudística para todas as suas decisões, possibilitando uma maior capacidade de atuação num ambiente mais complexo e contraditório. A legitimação da decisão passa a não depender totalmente da sua verdade e mesmo da sua correção, já que os procedimentos criam razões adicionais para aceitá-la, diminuindo a probabilidade de não-aceitação ${ }^{126}$.

\footnotetext{
${ }^{121}$ WEBER, Economia e Sociedade, Volume I. Brasília: UNB, 2000, pp. 139-198.

${ }^{122}$ HART, The Concept of Law. Oxford: Oxford University Press, 1997, pp. 79-99.

${ }^{123}$ Uma regra secundária também é criada por uma decisão. O procedimento constituinte, como afirmado anteriormente, é o procedimento que cria os demais procedimentos do Estado Democrático de Direito.

${ }^{124}$ Sobre o direito positivo como mecanismo reflexivo, ver Niklas LUHMANN, Sociologia do Direito, volume II, pp. 13 e ss. Segundo Luhmann, a reflexividade é caracterizada pela aplicação de um processo a si mesmo: regras sobre regras (regras secundárias ou procedimentais), o ensino do ensino (pedagogia), a pesquisa sobre a pesquisa (metodologia científica), a valorização de valores (ideologia), etc.

${ }_{125}$ Robert GRAFSTEIN, “The Legitimacy of Political Institutions", p. 68.

${ }^{126}$ Niklas LUHMANN, Legitimation durch Verfahren, pp. 24-27.
} 
As ciências sociais foram capazes de reconhecer amplamente que nenhuma formação política pode se apoiar somente na coação, devendo buscar uma forma de dominação mais estável e duradoura. Também é certo que o consenso não constitui um mecanismo de suporte suficiente para os regimes modernos: os opositores devem poder ser dominados em caso de necessidade ${ }^{127}$. Obviamente, certo grau de coação e consenso sempre existe no Estado Democrático de Direito, mas a soma da coação e do consenso é insuficiente para explicar a sua legitimação. O que as ciências sociais falham em levar em conta é aquilo que ocorre entre a coação e o consenso: a legitimação pelo procedimento.

A legitimação pelo procedimento ocorre entre a ameaça de uso da força e a existência do consenso, que constituem recursos escassos do sistema. A apresentação dos motivos reais que levaram à aceitação efetiva da decisão pode permanecer em suspenso $^{128}$. O processo de legitimação obtém uma aceitação quase desmotivada e automática das decisões, de forma semelhante ao que acontece no caso das verdades. A incerteza existente no momento da tomada da decisão é absorvida e o conteúdo da decisão é dogmatizado (transformado em ponto de partida inegável), devendo ser levado em conta mesmo quando se pretende decidir posteriormente em sentido contrário.

Uma instituição legítima é capaz, pode-se assim dizer, de antecipar que as suas decisões serão obedecidas sem ter que improvisar recompensas específicas, ameaças de uso da força ou justificações elaboradas para implantar cada decisão. A efetividade da instituição é minimamente contingente em relação aos motivos, interesses ou desejos particulares dos seus clientes ou participantes ${ }^{129}$.

\footnotetext{
${ }^{127}$ Niklas LUHMANN, Legitimation durch Verfahren, p. 28.

${ }^{128}$ Embora se prenda a uma concepção elitista da relação entre público, partidos políticos e administração pública, Claus Offe interpreta a legitimação pelo procedimento de maneira semelhante, ao afirmar que "se as condições de participação no processo político estiverem constituídas de tal forma que manifestações de dúvida quanto à justiça das estruturas e decisões políticas podem ser reprimidas ou absorvidas sem conseqüências, desaparece, para o detentor das competências decisórias estatais, a necessidade de mobilizar para cada umas das decisões a aprovação das bases”. Problemas Estruturais do Estado Capitalista, p. 265.

${ }^{129}$ Robert GRAFSTEIN, “The Legitimacy of Political Institutions”, p. 58. (Tradução livre). Em sentido análogo, Habermas: "the arrangement of formal democratic institutions and procedures permits administrative decisions to be made largely independently of specific motives of the citizens". Legitimation Crisis. London: Heinemann, 1976, p. 36.
} 
Numa sociedade complexa e que demanda uma produção massiva de decisões estatais, não é possível pressupor que quando o público aceita as decisões e se comporta como se o Estado fosse legítimo, ele está sendo motivado por um conjunto definido de princípios ou valores capazes de legitimar todas as decisões que exigem obediência, ou a maioria delas. Ao contrário disso, o simples fato de a decisão ter sido produzida é um importante determinante da sua aceitação ${ }^{130}$.

O alcance desse mecanismo, no entanto, é limitado: não se pode esperar que o público aceite uma decisão que ele considera manifestamente ilegítima. Essa margem de tolerância é dada pelos resultados agregados das interações que ocorrem na esfera pública, nas quais os participantes discutem sobre o que é correto ou desejado e, dessa forma, chegam a conclusões sobre o que é legítimo - ou aceitável. A legitimidade enquanto fórmula de contingência - ao delimitar a margem de tolerância dentro da qual o público está disposto a aceitar - indica os limites da legitimação pelo procedimento.

Ao oferecer canais nos quais determinadas ações são dotadas de significado institucionalmente relevante (votar, apelar de uma decisão judicial, etc.), as organizações estatais ao mesmo tempo edificam barreiras de indiferença em relação a outras ações, que passam a não ser institucionalmente reconhecidas como aptas a influenciar diretamente a produção de decisões ${ }^{131}$. A institucionalização de determinadas formas de provocar os procedimentos estatais corresponde à exclusão de formas de irritação que seriam igualmente possíveis. Trata-se também de um aprofundamento da diferenciação entre indivíduo e sociedade, já que com a institucionalização "o conjunto de comportamentos que pode encontrar reconhecimento político [e jurídico] queda fora da vontade e da intenção do indivíduo ${ }^{132,}$.

A legitimação pelo procedimento também busca reestruturar as expectativas daqueles que não foram contemplados pelo resultado dos procedimentos. A manifestação da discordância é desestimulada, tornada extremamente custosa e subordinada aos limites pré-estabelecidos da legalidade. Para isso, os procedimentos

\footnotetext{
${ }^{130}$ Robert GRAFSTEIN, “The Legitimacy of Political Institutions”, p. 59.

131 “As pretensões e exigências variadas e entre si contraditórias que provêm do povo heterogêneo só se tornam conteúdo de normas jurídicas vigentes e decisões coletivamente vinculantes quando percorrem os procedimentos jurídico-constitucionalmente e político-constitucionalmente estruturados e institucionalizados (procedimentos eleitorais, parlamentares ou legislativos, administrativos e jurisdicionais) e, dessa maneira, são selecionados sistemicamente". Marcelo NEVES, Entre Têmis e Leviatã: uma relação difícil, p. 165.

${ }^{132}$ Robert GRAFSTEIN, “The Legitimacy of Political Institutions”, p. 67.
} 
precisam generalizar a expectativa de que os derrotados poderão ser contemplados no futuro, já que as possibilidades decisórias estão sempre em aberto, bastando para isso que os procedimentos eleitoral, legislativo, administrativo ou judicial sejam novamente provocados dentro dos seus pressupostos.

A procedimentalização da legitimidade, nesse sentido, implica reconhecer que, no futuro, no caso de conflito entre valores e interesses, uma decisão poderá decidir - e normalmente decidirá - em sentido contrário a alguns deles ${ }^{133}$. A decisão produzida, por sua vez, deixa em aberto a possibilidade de a opinião derrotada ser novamente apreciada como alternativa plausível quando as circunstâncias se alterarem. Os descontentamentos do presente gerados pela decisão são deslocados para um futuro aberto e indeterminado, onde as reivindicações não contempladas poderão ser atendidas ${ }^{134}$.

Nesse ponto, o procedimento judicial se distingue dos demais, já que ele é programado para que a possibilidade de obter uma decisão favorável cesse em determinado momento. Não existem conflitos judiciais infinitos. Quando se esgotam as instâncias recursais e se forma a coisa julgada, já não é mais possível discutir judicialmente a questão (salvo raríssimas exceções), cabendo ao derrotado se conformar com a decisão ou exercer a sua insatisfação a um alto preço. Além disso, a regra da proibição do non liquet força a tomada da decisão, mesmo quando não existem condições apropriadas $^{135}$.

Já os procedimentos eleitoral, legislativo e administrativo permitem que os interesses e valores derrotados possam ser contemplados no futuro. Mesmo que o orçamento já tenha sido votado, o hospital que os cidadãos gostariam que fosse construído poderá ser contemplado no orçamento do ano seguinte. O candidato do partido $X$, derrotado na atual eleição, poderá ser eleito no futuro, caso a maioria deseje. O projeto de lei rejeitado no presente poderá ser aprovado no futuro, quando as circunstâncias políticas se alterarem.

\footnotetext{
${ }^{133}$ Niklas LUHMANN, Die Politik der Gesellschaft, p. 124.

${ }^{134}$ Segundo Ana Marie Drake, o fato de as decisões serem "provisórias" dá aos cidadãos razões para participar do processo decisório - mesmo quando discordam dos resultados particulares - porque a estrutura institucional da democracia permite que as questões controvertidas sejam analisadas novamente em caso de novos fatos ou de alteração da opinião pública. "Como resultado, nenhuma decisão tem que ser final e as conseqüências do dissenso são mitigadas por isso". Constructing Democratic Space: inclusion, efficacy and protest in deliberative democratic theory, pp. 100-101.

${ }^{135}$ Niklas LUHMANN, Law as a Social System, pp. 274-304.
} 
O deslocamento das expectativas do presente para o futuro garante a reprodução de um fluxo contínuo de demandas por decisões estatais. Caso essas demandas não existissem, o Estado Democrático de Direito se tornaria desnecessário e disfuncional, o que solaparia a sua legitimidade e colocaria fim à reprodução autopoiética do sistema político e do sistema jurídico. O processo de legitimação do Estado Democrático de Direito, portanto, é um processo contínuo de gerenciamento, canalização e controle de demandas. Para se legitimar, o Estado não pode ser mal-sucedido em atendê-las, mas paradoxalmente também não pode ser excessivamente bem-sucedido.

A reprodução do fluxo de demandas é facilitada pela estrutura das Constituições. As Constituições dos Estados Democráticos de Direito, principalmente as surgidas após a Segunda Guerra, são caracterizadas pela positivação de um extenso rol de direitos fundamentais, incluindo direitos sociais ${ }^{136}$. Segundo Alexy, todas as normas de direitos fundamentais, independentemente da sua formulação mais ou menos precisa, possuem a forma de princípios jurídicos ${ }^{137}$. Os princípios jurídicos são mandamentos de otimização e indicam que algo deve ser realizado na medida do possível, dentro das possibilidades jurídicas e fáticas existentes ${ }^{138}$.

A existência de mandamentos de otimização - que podem ser satisfeitos em graus variados, mas nunca totalmente - implica que sempre existirão lutas a serem travadas em nome da concretização dos direitos fundamentais. Sempre haverá mais liberdade, mais igualdade e mais dignidade constitucionalmente possíveis. A concretização dos direitos fundamentais é um jogo infinitamente em aberto no qual as expectativas não contempladas no presente podem obter reconhecimento num futuro onde o improvável se torna possível. Esse deslocamento contínuo de expectativas para o futuro faz com que as Constituições sejam muitas vezes acusadas de promover uma "ilusão desonesta ${ }^{139 "}$.

\footnotetext{
${ }^{136}$ Ricardo GUASTINI, “La Constitucionalización del Ordenamiento Jurídico: El Caso Italiano”. In Miguel CARBONELL (Ed.), Neoconstitucionalismo(s). Madrid: Trotta, 2003, pp. 52-53.

${ }^{137}$ Robert ALEXY, Teoria dos Direitos Fundamentais, p. 575.

138 "Princípios são, por conseguinte, mandamentos de otimização, que são caracterizados por poderem ser satisfeitos em graus variados e pelo fato de que a medida devida da sua satisfação não depende somente das possibilidades fáticas, mas também das possibilidades jurídicas". Robert ALEXY, Teoria dos Direitos Fundamentais, p. 90.

${ }^{139}$ Marx, em sua crítica às declarações de direitos das constituições francesas, sobretudo a de 1848 , identificou esse fenômeno, ao afirmar que elas consistiam "no artifício de prometer liberdade total, de garantir belos princípios e deixar a sua aplicação, os detalhes, para a legislação infraconstitucional”. Karl
} 
As normas constitucionais de direitos fundamentais garantem somente uma proteção prima facie, mas não uma proteção em definitivo. $\mathrm{O}$ direito à liberdade, por exemplo, é protegido prima facie, mas pode não ser protegido em definitivo numa situação concreta, pois isso depende do seu sopesamento com outros direitos fundamentais igualmente válidos. Uma norma que proíbe o fumo em locais públicos, por exemplo, restringe a liberdade dos fumantes em determinadas situações em prol do direito à saúde dos não fumantes. Apesar de garantida prima facie - em abstrato - a liberdade dos fumantes não foi contemplada nessa situação concreta. Isso não impede que no futuro outra norma venha re-autorizar o fumo em locais públicos, caso o contexto político-jurídico se altere.

Os direitos fundamentais ordenam que algo seja realizado na medida do possível, dentro das possibilidades jurídicas e fáticas existentes. Como não existem direitos fundamentais absolutos, o próprio conceito de mandamento de otimização já prevê que a realização de um direito fundamental pode ser restringida por direitos fundamentais colidentes ${ }^{140}$. Nem tudo aquilo que é garantido prima facie prevalecerá em definitivo. A prevalência em definitivo só ocorre quando um sopesamento é realizado, formando-se uma regra de conduta que indica o que deve ser feito na situação concreta. Essa regra de conduta pode ser criada pelo procedimento legislativo ou pelo procedimento judicial, normalmente em caso de ausência de uma regra de conduta criada pelo legislativo.

Aqueles que nutrem esperanças de possuir um direito definitivo somente com base na existência de um direito prima facie criam expectativas sem fundamento ${ }^{141}$. A concessão de um direito definitivo (a produção de uma regra de conduta) com base em um direito prima facie depende dos direitos que com ele colidem e do seu peso relativo no caso concreto. Quem demanda uma decisão legislativa somente com base em um direito prima facie não tem a garantia de um direito definitivo, mas somente o direito a um sopesamento de princípios ${ }^{142}$. Se esse sopesamento for desfavorável, os derrotados poderão (i) se conformar com o resultado da decisão, reestruturando as suas

MARX, Die Konstitution der Französischen Republik. Berlin: Dietz, 1973, pp. 503-504. Apud: Virgílio Afonso da SILVA, Direitos Fundamentais: conteúdo essencial, restrições e eficácia, p. 145.

${ }^{140}$ Virgílio Afonso da SILVA, Direitos Fundamentais: conteúdo essencial, restrições e eficácia, p. 140.

${ }^{141}$ Virgílio Afonso da SILVA, Direitos Fundamentais: conteúdo essencial, restrições e eficácia, pp. 145146.

${ }^{142}$ Virgílio Afonso da SILVA, Direitos Fundamentais: conteúdo essencial, restrições e eficácia, pp. 145146. 
expectativas, (ii) adiar as suas expectativas para o futuro ou (iii) manter as expectativas frustradas, a um alto custo.

As Constituições dos Estados Democráticos de Direito só positivam valores que aceitam ser confrontados com outros valores no jogo democrático ${ }^{143}$. Os valores democráticos são valores adiáveis, cuja realização não é pretendida a qualquer custo. $\mathrm{O}$ fanatismo valorativo se encontra excluído do texto constitucional. As Constituições democráticas são regidas pelo chamado princípio da não-identidade, que proíbe que elas se identifiquem com concepções totalizadoras de caráter moral, religioso, filosófico ou político ${ }^{144}$. Uma Constituição adepta de valores totalitários, tolhedora do pluralismo, não poderia nem ao menos ser considerada uma Constituição, mas um conjunto de valores que pretendem ser diretamente válidos para todas as esferas sociais, controlando-as $^{145}$.

A estratégia de deslocar os descontentamentos para um futuro aberto e indeterminado possui limites, como veremos nos capítulos seguintes. O Estado não pode se legitimar somente com base na esperança de que o futuro corrija a sua atuação desastrosa no presente. As normas jurídicas não podem ser meros compromissos dilatórios, desprovidos de força normativa ${ }^{146}$. A frustração contínua das expectativas do público possui conseqüências, que podem variar da diminuição do apoio específico aos governantes e aos partidos políticos à diminuição do apoio difuso ao sistema.

\subsection{A Destautologização do Conceito de Legitimidade.}

O tópico anterior buscou oferecer uma definição do conceito de legitimidade. $\mathrm{O}$ desafio da abordagem sociológica, no entanto, não consiste apenas em definir um conceito, mas também em destautologizá-lo, condição necessária para que ele se torne útil para a pesquisa empírica. A legitimidade é uma forma de dois lados: do lado

\footnotetext{
${ }^{143}$ Niklas LUHMANN, Die Politik der Gesellschaft, p. 124.

${ }^{144}$ Marcelo NEVES, A Constitucionalização Simbólica, pp. 73-74.

${ }^{145}$ Marcelo NEVES, A Constitucionalização Simbólica, pp. 73-74.

${ }^{146}$ Marcelo NEVES, A Constitucionalização Simbólica, pp. 73-74.
} 
positivo da fórmula, encontra-se a própria legitimidade. Do seu lado negativo, encontrase a ilegitimidade. Segundo Robert Grafstein, as visões clássicas da legitimidade costumam ser tautológicas justamente porque não são capazes de apontar o lado negativo da forma: o comportamento que mede a legitimidade é, ao mesmo tempo, o comportamento que a define ${ }^{147}$.

Se o comportamento escolhido para mensurar a legitimidade a define em último grau, então a diferença entre identificar corretamente os indicadores comportamentais da legitimidade e estabelecer arbitrariamente um conjunto de indicadores comportamentais se torna obscura ${ }^{148}$. Para evitar que isso aconteça, Grafstein defende que a legitimidade não reside no comportamento dos indivíduos que obedecem ou desobedecem às decisões estatais, mas nas próprias instituições. Quem atribui um sentido política ou juridicamente relevante aos diversos comportamentos possíveis são o sistema político e o sistema jurídico, e não os indivíduos isoladamente. É dessa maneira que deve ser interpretado o que Kelsen chamou de diferença entre o "sentido subjetivo" e o "sentido objetivo" da ação. ${ }^{149}$

Tanto o ato de preencher um pedaço de papel como o ato de apertar um botão podem ser interpretados como um voto, uma comunicação do procedimento eleitoral. Da mesma forma, não importa o quanto os cidadãos atribuam à sua recusa em obedecer às leis o rótulo de "desobediência civil". O sentido vinculante dessa ação para o sistema jurídico será estabelecido no interior do procedimento judicial, e poderá ser distinto do sentido atribuído pelos atores. O sistema político, da mesma maneira, pode interpretar e normalmente o faz - a desobediência civil como uma afronta ao seu poder e como uma autorização para o uso da força.

Segundo Grafstein, um Estado Democrático de Direito legítimo não precisa tomar medidas adicionais para garantir que os comportamentos dos cidadãos se circunscrevam às opções juridicamente permitidas. Um Estado legítimo não precisa forçar a aceitação das suas decisões caso a caso, justamente porque ela acontece de maneira espontânea. $\mathrm{O}$ dissenso em torno do resultado dos procedimentos, quando ocorre, é exercido dentro dos pressupostos dos procedimentos ou dentro dos limites

\footnotetext{
${ }^{147}$ Robert GRAFSTEIN, “The Legitimacy of Political Institutions”, p. 55.

${ }^{148}$ Robert GRAFSTEIN, “The Legitimacy of Political Institutions”, p. 55.

${ }^{149}$ Hans KELSEN, Teoria Pura do Direito. Tradução de João Baptista Machado. São Paulo: Martins Fontes, 2000, p. 3.
} 
tolerados pelo direito, ou seja, dentro das opções institucionalmente respaldadas. Quando um regime democrático é legítimo:

[...] os candidatos que perdem a eleição e os cidadãos que votaram neles aceitam o resultado eleitoral. A insatisfação com o resultado é expressa através do canal institucional proporcionado pela próxima eleição. De maneira similar, as decisões jurídicas normalmente desapontam uma das partes da disputa. Quando o sistema jurídico é legítimo, a parte desapontada agirá através dos canais legais: apelações, tentativas legais de mudar a lei ou simples obediência. Finalmente, a legislação aprovada através do voto majoritário pode desapontar quantos cidadãos ela quiser. Apesar disso, se o procedimento legislativo é legítimo, os cidadãos irão se adaptar aos seus resultados ${ }^{150}$.

Para que isso ocorra, não basta que os procedimentos estatais atribuam papéis sociais (eleitor, público, governo, oposição, etc.). É preciso que exista a competência necessária para que as informações associadas a esses papéis sejam processadas pelos indivíduos, o que a sociologia chama de competência para o desempenho de papéis, ou role competence ${ }^{151}$. A role competence é precondição para a internalização das expectativas de comportamento referentes aos papéis sociais que são política ou juridicamente relevantes e para o aprendizado (reestruturação de expectativas). Não se trata de uma afirmação psicologista, já que a competência para o desempenho de papéis existe na sociedade, e não na consciência dos indivíduos ${ }^{152}$.

Quando essa competência não é criada pelos procedimentos estatais, mas somente assumida, a legitimidade dos procedimentos não está em questão. Quando a competência se torna um problema, a legitimação é assegurada transformando o problema de competência num problema procedimental (a sua absorção e intermediação

\footnotetext{
${ }^{150}$ Robert GRAFSTEIN, “The Legitimacy of Political Institutions”, p. 59. (Tradução livre).

${ }^{151}$ Robert GRAFSTEIN, “The Legitimacy of Political Institutions”, p. 64.

${ }^{152}$ A exclusão social é um obstáculo à role competence. É dessa maneira que deve ser compreendida a afirmação de Luhmann de que no âmbito da exclusão extrema os seres humanos são reduzidos à condição de corpos, justamente porque a atribuição de papéis sociais lhes é tolhida. A role competence pressupõe a inclusão social. Niklas LUHMANN, Inclusión y Exclusión, in: Complejidad y Modernidad: de la unidad a la diferencia. Tradução de Josetxo Berian y José María García Blanco. Madrid: Trotta, 1998, pp. 193-194.
} 
através de uma decisão). ${ }^{153}$ Caso o Estado precise tomar medidas adicionais para garantir a competência, a sua legitimidade está diminuída ${ }^{154}$. Nessa situação, os procedimentos estatais não são capazes de recanalizar o dissenso para o seu interior e o dissenso não é exercido dentro dos canais institucionais fornecidos pelos procedimentos (próximas eleições, próximas votações parlamentares, ações ou recursos judiciais ou administrativos, discursos na esfera pública).

Nem todo comportamento ilegal pode ser considerado um indicador de ilegitimidade. A criminalidade, por si só, não indica insatisfação com as decisões ou com os procedimentos estatais. Um crime passional dificilmente poderá ser compreendido como uma manifestação de repúdio ao governo ou ao Estado Democrático de Direito. Um comportamento que indica a ilegitimidade é um comportamento tematizado politicamente e pertencente à esfera pública e, portanto, uma comunicação do sistema político. Isso implica que só podem ser considerados politicamente relevantes (no sentido de pertencentes ao sistema político) os comportamentos que conseguem atingir a esfera pública ${ }^{155}$.

Embora nada impeça que uma manifestação individual atinja a esfera pública, a intensidade da ilegitimidade depende da dimensão material (a amplitude temática), social (o número de participantes), temporal (a duração) e espacial (a abrangência territorial) das manifestações ${ }^{156}$. As manifestações com um pequeno número de participantes e com pequena abrangência territorial e temática são facilmente recanalizadas para os procedimentos estatais, controladas por meio da repressão ou mesmo passíveis de cessar espontaneamente.

\footnotetext{
${ }^{153}$ Robert GRAFSTEIN, “The Legitimacy of Political Institutions”, p. 64.

${ }^{154}$ Robert GRAFSTEIN, “The Legitimacy of Political Institutions”, p. 64.

${ }^{155}$ Ninguém saberá que o presidente foi deposto enquanto isso não for comunicado, por exemplo. O que não é comunicado não pertence à sociedade (que é formada por comunicações), e a comunicação que não é selecionada a partir dos critérios de relevância do sistema político não pertence ao sistema político, mas ao seu ambiente intra-social. Ver as considerações feitas no capítulo anterior sobre a importância dos meios de comunicação de massa para que o sistema político observe a si mesmo.

${ }^{156}$ Segundo Luhmann, a comunicação é formada por três dimensões de sentido: a dimensão material (Sachdimension), que cria a diferença temática entre algo e todo o resto; a dimensão social (Sozialdimension), que cria a diferença entre ego e alter, e a dimensão temporal (Zeitdimension), que cria a diferença entre o antes e o depois (Social Systems, pp. 74-92). Jorge Galindo Monteagudo fala na existência de uma quarta dimensão de sentido, a dimensão espacial, que indica o local onde foi produzida a comunicação e que não pode ser ignorada ou reduzida a nenhuma das outras três dimensões ("La Teoría Sistémica de Niklas Luhmann: alcances e limites", p. XXXV e ss.).
} 
Os comportamentos que indicam a ilegitimidade são comportamentos que manifestam dissensos em relação aos próprios procedimentos do Estado Democrático de Direito (dissensos de segundo grau), de maneira ilegal e/ou considerada ameaçadora pelo poder. Como os procedimentos podem ser alterados dentro dos limites permitidos pela Constituição, os comportamentos que indicam a ilegitimidade manifestam não apenas o dissenso em relação aos procedimentos, mas também descrença em relação à possibilidade de alterá-los dentro dos canais institucionais existentes. Segundo Anna Marie Drake, aqueles que protestam negam o próprio grupo deliberativo ${ }^{157}$.

Esses comportamentos indicam perda de apoio difuso (disposição generalizada para aceitar as decisões), e não a mera perda de apoio específico (apoio aos governantes). ${ }^{158}$ Segundo David Easton, a obediência e a desobediência não são componentes do apoio difuso (ou da ausência de apoio difuso), mas conseqüências e indicadores do nível existente de apoio difuso ${ }^{159}$. Easton também defende que desobediência às decisões estatais deve ser contextualizada e analisada caso a caso, para que o seu sentido político seja reconhecido ou descartado.

Os comportamentos que indicam a ilegitimidade geralmente se manifestam sob a forma de protestos, conflitos discursivos intensos na esfera pública (incitação à revolta, ameaças ao governo e aos seus apoiadores, hate-speech, etc.) ou desobediência civil ${ }^{160}$. Essas comunicações só ganham relevância política a partir do momento em que atingem a esfera pública e, para que isso aconteça, elas precisam vencer os obstáculos de difusão (as comunicações precisam ser amplamente divulgadas, ao menos para o público interessado) e de mobilização e organização da ação coletiva.

\footnotetext{
${ }^{157}$ Anna Marie DRAKE, Constructing Democratic Space: inclusion, efficacy and protest in deliberative democratic theory, p. 92 e ss.

${ }^{158}$ É importante salientar que "apoio" (conceito utilizado aqui em sentido amplo) não é a mesma coisa que "consenso". Enquanto no conceito de consenso os participantes formulam um acordo sobre algo a partir das mesmas razões, o conceito de apoio prescinde essa exigência: ele também engloba as situações nas quais os participantes chegam a um acordo por motivos distintos (com objetivos estratégicos e perlocucionários).

159 " [...] it does not seem appropriate to adopt compliance as a necessary ingredient of support. Rather, it can be more usefully conceived as a variable whose relationship to support needs to be established through interpretation of the context in which the relevant attitudes and behavior appear. [...] Compliance is perhaps more appropriately construed as a determinant, consequence or possible indicator of support rather than as one of its dimensions". David EASTON, "A Re-Assessment of the Concept of Political Support", p. 455.

${ }^{160} \mathrm{O}$ presente tópico não pretende estabelecer critérios formais que permitam classificar determinadas comunicações ou ações como indicadores da ilegitimidade, substituindo a pesquisa empírica. O objetivo do presente tópico consiste apenas em oferecer parâmetros que orientem a pesquisa empírica e que destautologizem o conceito de legitimidade.
} 
Segundo estudo empírico realizado por Earl, Soule e McCarthy sobre os protestos estadunidenses das décadas de 1960 e 1970, o fato de um protesto ser considerado ameaçador pelas autoridades é influenciado por três variáveis: (i) o seu tamanho, (ii) o uso de táticas de confronto e (iii) a presença de objetivos radicais ${ }^{161}$. Essas três variáveis estão diretamente relacionadas à freqüência e à intensidade da repressão policial ${ }^{162}$. A atuação policial também possui relação direta com a capacidade da polícia (tamanho e preparação dos seus contingentes) e a presença de movimentos sociais entre os participantes ${ }^{163}$.

A atuação da polícia não é a única forma de controlar os protestos e evitar que comunicações potencialmente deslegitimadoras circulem na esfera pública. O Estado Democrático de Direito dispõe de inúmeras estratégias menos coativas para alcançar esses resultados, já que, sob determinadas circunstâncias, a repressão policial pode aumentar a dimensão, a intensidade e a frequiência dos protestos existentes, ao invés de controlá-los ${ }^{164}$. Essas estratégias incluem a vigilância, a produção de comunicações que confundem e "desinformam" o público e o assédio aos líderes dos protestos ${ }^{165}$. O Estado também pode utilizar discursos hostis contra os dissidentes - argumentos ad hominem que os caracterizam como inimigos do povo ou da nação, terroristas, subversivos, etc. - ou simplesmente disseminar o medo na população, mecanismo amplamente utilizado nos EUA após os ataques terroristas de 11 de setembro de $2001 .{ }^{166}$

Outra estratégia incorporada nas Constituições diz respeito aos instrumentos de exceção. Em momentos de graves comoções internas, é possível suspender parcialmente

\footnotetext{
161 Jennifer EARL, Sarah A. SOULE e John D. McCARTHY, "Protest under Fire? Explaining the Policing of Protest". In American Sociological Review, Vol. 68, No. 4 (Aug., 2003), pp. 581-606.

${ }^{162}$ EARL; SOULE; McCARTHY, "Protest under Fire? Explaining the Policing of Protest".

${ }^{163}$ EARL; SOULE; McCARTHY, "Protest under Fire? Explaining the Policing of Protest".

${ }^{164}$ Karl-Dieter OPP e Wolfgang ROEHL, "Repression, Micromobilization, and Political Protest". In Social Forces, Vol. 69, No. 2 (Dec., 1990), pp. 521-547.

${ }^{165}$ EARL; SOULE; McCARTHY, "Protest under Fire? Explaining the Policing of Protest". Nos últimos anos, muito se tem discutido sobre a "criminalização do protesto" e a "criminalização dos movimentos sociais". Nesse caso, os participantes e as instâncias estatais atribuem sentidos diversos às mesmas ações, e o direito não é capaz de mediar satisfatoriamente essa atribuição de sentido. Numa situação de criminalização discricionária dos protestos e da oposição e de uso discricionário do direito, da persecução judicial e da repressão policial, não é mais possível falar na existência da democracia e da rule of law.

${ }^{166} \mathrm{O}$ Homeland Security Advisory System, escala de cores para ameaças terroristas, foi utilizado mais por razões políticas do que por motivos concernentes à segurança. Foi observada correlação entre a variação na popularidade de George W. Bush e a mudança de cores na escala. Brigitte NACOS, Yaeli BLOCHELKON e Robert SHAPIRO, "Prevention of Terrorism in Post-9/11 America: New Coverage, Public Perceptions, and the Politics of Homeland Security". In Terrorism and Political Violence 20(1) (2008).
} 
a legalidade através da própria legalidade. Através da suspensão parcial e temporária dos direitos e garantias constitucionais - como o direito de reunião, a liberdade de expressão e os requisitos processuais para detenções e prisões - o Estado alcança uma liberação adicional do seu poder instrumental, o que permite alcançar resultados que não podem ser alcançados nos momentos de "normalidade constitucional". ${ }^{167}$

Obviamente, o Estado também pode tentar recanalizar as discordâncias para o interior dos procedimentos - através de negociações e acordos, cedendo às exigências dos discordantes ou deslocando-as para o futuro. Os procedimentos estatais também podem ser redesenhados para se tornarem mais seguros, equitativos e inclusivos. Existem evidências empíricas de que o aumento da legitimidade dos procedimentos aumenta a obediência às decisões políticas e jurídicas. Voltaremos a esse assunto mais adiante.

\subsection{O Ciclo de Legitimação do Estado Democrático de Direito.}

Os resultados agregados das interações que ocorrem na esfera pública indicam aquilo que o público está disposto a aceitar. É dessa forma que a legitimidade atua como fórmula de contingência do sistema político, indicando os limites dentro dos quais podem ser produzidas decisões passíveis de aceitação. Ao mesmo tempo, esses resultados indicam que, dentro desses limites, haverá uma disposição generalizada para a aceitação. Desde que se mantenham dentro da margem de tolerância do público, o conteúdo das decisões se legitima pela obediência ao procedimento e os eventuais dissensos são exercidos dentro dos canais institucionais existentes.

O mero dissenso em torno do resultado das decisões não é um fator de deslegitimação. Os procedimentos estatais não são programados para evitar o surgimento de dissensos, mas para canalizá-los e intermediá-los através da produção de decisões. A democracia liberal é caracterizada por direitos fundamentais que protegem o

${ }^{167}$ Para uma ampla discussão a respeito, embora não sob o viés sociológico, Gilberto BERCOVICI, Soberania e Constituição: Para uma Crítica do Constitucionalismo. São Paulo: Quartier Latin, 2008. 
exercício comunicativo do dissenso contra ameaças internas e externas. Segundo Bobbio, "apenas onde o dissenso é livre para se manifestar o consenso é real, e apenas onde o consenso é real o sistema pode proclamar-se com justeza democrático ${ }^{168, "}$.

Além disso, em alguns casos, os procedimentos podem até mesmo fomentar o surgimento de dissensos. Mesmo que a imensa maioria dos cidadãos deseje que um governante se mantenha no cargo, o final do seu mandato implica que deve ser concedida uma nova chance à oposição através da realização de novas eleições, nas quais o candidato minoritário poderá confrontar suas opiniões com as opiniões do atual governante, bem como mobilizar recursos financeiros e apoio para as suas propostas ${ }^{169}$.

Os dissensos produzidos por uma decisão e que não são recanalizados para o interior dos procedimentos exigem a tomada de medidas adicionais para a sua contenção e para a reestruturação das expectativas dos derrotados. Esses dissensos passam então a configurar conflitos. Segundo Luhmann, os conflitos são sistemas sociais que se desenvolvem parasitariamente no interior de outros sistemas sociais e que tendem a mobilizar todos os recursos do sistema parasitado para a sua resolução ${ }^{170}$. Eles bloqueiam parcialmente o ciclo de legitimação do Estado Democrático de Direito e, caso não sejam controlados mesmo após a tomada de medidas coercitivas adicionais, podem colocar em risco a reprodução autopoiética das organizações estatais e a sua capacidade de produzir decisões coletivamente vinculantes e estabilizar expectativas normativas.

O Estado Democrático de Direito se legitima na medida em que os seus procedimentos são capazes de absorver os conflitos e dissensos socialmente difusos e intermediá-los a partir da produção de decisões. Essas decisões, por sua vez, devem ser capazes de gerar consenso e apoio que realimentam a opção selecionada e dissensos que se deixam recanalizar para o interior dos procedimentos. Um Estado legítimo é aquele que não precisa tomar medidas adicionais para garantir que os dissensos sejam recanalizados para o interior dos procedimentos, pois a decisão é aceita mesmo quando há discordância em relação ao seu conteúdo.

\footnotetext{
${ }^{168}$ Norberto Bobbio, O Futuro da Democracia. São Paulo: Paz e Terra, 2004, p. 75.

${ }^{169}$ Segundo Luhmann, o direito é socialmente útil não apenas quando captura os conflitos, mas também quando cria conflitos e então disponibiliza a sua complexidade, em níveis adequados, para tratá-los. Social Systems, p. 375.

${ }^{170}$ Niklas LUHMANN, Die Politik der Gesellschaft, p. 133.
} 


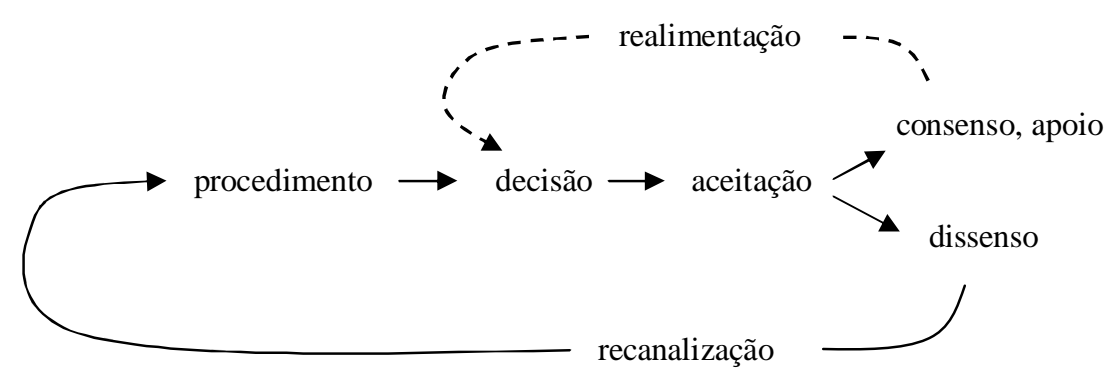

Figura 1. O Ciclo de Legitimação do Estado Democrático de Direito.

O ciclo de legitimação também engloba as situações onde o dissenso não é exercido dentro dos limites do procedimento que o originou, mas mesmo assim é exercido dentro dos limites democráticos da esfera pública. Uma passeata pacífica contra uma decisão judicial ou legislativa não pode mudar diretamente a decisão judicial ou "desaprovar" uma lei, mas pode influenciar indiretamente o procedimento visado para a produção de uma decisão posterior, em sentido contrário (quando isso for possível). Cada procedimento estatal possui um grau de abertura cognitiva distinta para esse tipo de influência: ela é maior no caso do procedimento legislativo e administrativo e menor do caso do procedimento judicial ${ }^{171}$.

\subsection{A Justiça Procedimental.}

Como dito anteriormente, o consenso e a coação são incapazes de explicar como o Estado Democrático de Direito mantém a sua capacidade de produzir decisões coletivamente vinculantes em um ambiente complexo e contraditório. A estruturação do procedimento decisório através de regras secundárias, nesse sentido, ocupa um papel

171 "Courts work under a much higher degree of cognitive self-isolation compared with legislators and contracting parties”. Niklas LUHMANN, Law as a Social System, p. 293. 
central nessa explicação. Como já percebido por Weber, o Estado Democrático de Direito se legitima, em grande parte, porque as suas decisões obedecem a procedimentos gerais e previamente definidos.

Isso não significa que basta criar um procedimento para que qualquer decisão se legitime. A legitimação pelo procedimento não é uma panacéia, mas um mecanismo que atua sob determinadas condições. Segundo Luhmann, a legitimação pelo procedimento ocorre quando os procedimentos são incertos quanto ao seu resultado ${ }^{172}$ e quando são considerados equitativos ${ }^{173}$. Além disso, segundo Marcelo Neves, o Estado Democrático de Direito se legitima na medida em que os seus procedimentos permanecem abertos à pluralidade de valores e interesses presentes na esfera pública e à autonomia dos diversos sistemas funcionais ${ }^{174}$.

A legitimação pelo procedimento, portanto, está diretamente relacionada com três variáveis: a confiabilidade, a equidade e a inclusividade dos procedimentos ${ }^{175}$. Um procedimento é confiável quando as suas premissas decisórias são obedecidas (incluindo os direitos fundamentais) e quando ele é capaz de neutralizar as influências consideradas indesejadas. Um procedimento é equitativo quando os cidadãos são tratados de maneira igualitária e quando os diversos pontos de vista são levados em conta na produção da decisão ${ }^{176}$. Por fim, um procedimento é inclusivo quando não existem barreiras formais ou materiais que impedem os cidadãos de acessá-lo em igualdade de condições.

Enquanto a equidade diz respeito ao tratamento dispensado no interior do procedimento, a inclusividade diz respeito às condições prévias necessárias para que o procedimento possa ser acessado por todos os cidadãos. Um procedimento pode ser confiável e equitativo e, ao mesmo tempo, inacessível para grande parte da população: os tribunais podem ser compostos por juízes bem treinados, incorruptíveis e que

\footnotetext{
${ }^{172}$ Niklas LUHMANN, Legitimation durch Verfahren, p. 51.

173 "Assim como no sistema jurídico, recorremos para estabelecer a fórmula de contingência do sistema político à idéia de um procedimento equitativo (fairen), cujo resultado não é determinado de antemão pela utilização do poder. Um procedimento deve ser iniciado com uma incerteza garantida quanto ao seu resultado". Niklas LUHMANN, Die Politik der Gesellschaft, p. 124. (Tradução livre).

${ }^{174}$ Marcelo NEVES, Entre Têmis e Leviatã: uma relação difícil, p. 136 e ss.

175 Características muito similares são listadas por Amy GANGL, "Procedural Justice Theory and Evaluations of the Lawmaking Process". Political Behavior, Vol. 25, No. 2 (Jun., 2003), p. 121.

${ }^{176}$ Ver as considerações de Teubner sobre o princípio altera pars audiatur (ouvir a outra parte), no caso específico do direito. Gunther TEUBNER, "Altera Pars Audiatur: Law in the Collision of Discourses", pp. 150-176.
} 
decidem de maneira imparcial e justa. Ao mesmo tempo, os altos custos de litigância podem torná-los inacessíveis para quem não pode pagar as taxas judiciárias e para quem não possui acesso a advogados gratuitos.

Os procedimentos considerados confiáveis, equitativos e inclusivos trazem um potencial de conflito muito baixo, pois não são considerados diretamente responsáveis pelo conteúdo da decisão: são considerados "vazios de conteúdo". Já os procedimentos considerados não confiáveis, não equitativos e não inclusivos são incapazes de canalizar satisfatoriamente a conflituosidade socialmente difusa e intermediá-la através da produção de uma decisão e, dessa forma, são incapazes de obter uma disposição generalizada para a aceitação das suas decisões.

O procedimento eleitoral, por exemplo, necessita de um grau de confiabilidade absoluto. A sua suscetibilidade a falhas é capaz de influenciar diretamente o resultado de uma eleição, principalmente quando a diferença de votos entre os candidatos é pequena. As fraudes ou suspeitas eleitorais são fagulhas lançadas diretamente contra o barril de pólvora da insatisfação popular. Acontecimentos dessa natureza não são privilégio de regimes autoritários ou de democracias excessivamente frágeis: as eleições presidenciais estadunidenses de 2000 despertaram moderada desconfiança no público $^{177}$, e resultados ainda mais desastrosos ocorreram nas eleições presidenciais mexicanas de 2006.

Embora o Estado Democrático de Direito tenha adquirido um considerável grau de independência em relação ao consenso em torno do conteúdo das suas decisões, ele não foi capaz de obter a mesma independência quando se trata do consenso em torno dos procedimentos em si. É nesse sentido que Marcelo Neves afirma que o consenso em torno dos procedimentos é "pressuposto imprescindível" para a legitimação do Estado Democrático de Direito ${ }^{178}$. Em nossa opinião, entretanto, a ausência de consenso procedimental só se torna um fator de deslegitimação empiricamente verificável quando é manifestada fora dos limites proporcionados pelo Estado Democrático de Direito

\footnotetext{
${ }^{177}$ Estudos demonstram que a aceitação dos resultados eleitorais de 2000 dependeu em grande parte do fato de a Suprema Corte, uma instituição com alto grau de legitimidade, ter produzido uma decisão sobre a questão (caso Bush v. Gore). J. L. GIBSON, G. A. CALDIERA e L. K. SPENCE, "The Supreme Court and the U.S. Presidencial Election of 2000: wounds, self-inflicted or otherwise?" In British Journal of Political Science 33, 2003, pp. 535-556. Trata-se de um caso típico de troca de prestações de legitimação: o sistema jurídico agiu de modo a absorver e intermediar um conflito originado no sistema político.

${ }^{178}$ Entre Têmis e Leviatã: uma relação difícil, p. 151.
} 
(justamente porque o público passa a considerar que os procedimentos não podem ser alterados dentro desses limites).

A mera ausência de consenso em torno dos procedimentos não é um fator de deslegitimação quando existem expectativas cognitivas generalizadas de que os procedimentos podem ser alterados dentro dos limites do Estado Democrático de Direito ou quando essas expectativas são eficazmente deslocadas para o futuro através de mecanismos dilatórios. Além disso, a manifestação de comportamentos que indicam a ilegitimidade precisa superar os já mencionados obstáculos de mobilização e organização da ação coletiva.

Obviamente, quando os procedimentos do Estado Democrático de Direito são questionados de maneira generalizada, a sua capacidade de produzir uma disposição generalizada para a aceitação das suas aceitações é comprometida, e a legitimação pelo procedimento dá lugar a duas situações: (i) a reprodução do poder pelo uso da força (o que é incompatível com o conceito de Estado Democrático de Direito) ou (ii) a situação identificada por Easton na qual as decisões só podem se legitimar materialmente, enquanto produzirem resultados considerados satisfatórios pelo público (ou seja, pelo consenso ou pela anuência instrumental ${ }^{179}$ ). Na ausência de apoio difuso, resta ao Estado confiar no apoio específico às realizações dos governantes ou na utilização da força, que constituem recursos mais instáveis em termos temporais, sociais e materiais $^{180}$.

As afirmações feitas até aqui sobre a importância da confiabilidade, equidade e inclusividade dos procedimentos encontram confirmação empírica na tradição da justiça procedimental (procedural justice). As investigações sobre a justiça procedimental se iniciaram nos Estados Unidos na metade da década de 1970, a partir da constatação de que a maneira como um processo decisório é avaliado depende não apenas do conteúdo das decisões que ele produz, mas também do tipo de procedimento utilizado ${ }^{181}$. Isso é

\footnotetext{
${ }^{179}$ David EASTON, “A Re-Assessment of the Concept of Political Support”.

180 Trata-se de uma conclusão oposta à conclusão de Claus Offe. Segundo Offe, o Estado recorre à legitimação procedimental quando já não pode recorrer à legitimação conteudística. Na verdade, sob a lógica funcional, o Estado recorre à pura legitimação conteudística (ou à força) quando não é capaz de criar procedimentos considerados confiáveis, equitativos e inclusivos que absorvam os dissensos resultantes do seu processo decisório. Problemas Estruturais do Estado Capitalista, p. 271.

${ }^{181}$ Amy GANGL, "Procedural Justice Theory and Evaluations of the Lawmaking Process".
} 
válido não só para os procedimentos políticos e jurídicos, mas também para os procedimentos das organizações privadas.

Em determinadas circunstâncias, as considerações procedimentais possuem um peso muito maior do que as considerações conteudísticas. Segundo Amy Gangl, isso ocorre quando o procedimento é considerado aberto e inclusivo. Quando o procedimento é considerado fechado ou parcial, as considerações conteudísticas sobre a decisão possuem um peso maior do que as considerações procedimentais e um peso maior do que possuiriam caso o procedimento fosse considerado aberto e inclusivo ${ }^{182}$. Um procedimento considerado aberto e inclusivo também é capaz de obter mais consenso em torno das suas decisões do que um procedimento fechado e $\operatorname{parcial}^{183}$.

O estudo de Gangl também concluiu que o peso das considerações procedimentais é influenciado pela natureza da questão em disputa. Quando a disputa envolve questões de forte conteúdo moral ou ético, a legitimidade do processo decisório é mais fortemente influenciada por considerações sobre o resultado da decisão do que no caso de disputas que envolvem questões pragmáticas ${ }^{184}$. Por sua vez, quando a disputa envolve questões de forte conteúdo moral ou ético, a legitimidade do processo decisório é menos influenciada por considerações procedimentais do que no caso de disputas que envolvem questões pragmáticas.

O estudo mais completo sobre a justiça procedimental é o estudo de Tom Tyler Why People Obey the Law, que além de compilar vários estudos anteriores sobre o tema, também produziu resultados extremamente detalhados a partir de duas ondas de entrevistas realizadas com a população de Chicago. O estudo de Tyler também concluiu que a forma como as autoridades são avaliadas depende fortemente das avaliações sobre a justiça dos procedimentos decisórios utilizados ${ }^{185}$. Tyler concluiu que os julgamentos sobre a justiça do procedimento influenciam os julgamentos sobre o resultado do procedimento, e não o contrário (os cidadãos não podem considerar o procedimento

\footnotetext{
${ }^{182}$ Amy GANGL, "Procedural Justice Theory and Evaluations of the Lawmaking Process".

183 "It might be that when the process is portrayed as balanced and inclusive, people are more likely to report that the decision is consistent with their preferred outcome, even though their response in the first survey indicates otherwise". Amy GANGL, "Procedural Justice Theory and Evaluations of the Lawmaking Process".

${ }^{184}$ Amy GANGL, "Procedural Justice Theory and Evaluations of the Lawmaking Process". A pesquisa foi conduzida utilizando o aborto como tema de forte conteúdo moral e o aumento do gasto público como tema de natureza pragmática.

${ }^{185}$ Tom Tyler, Why People Obey the Law, p. 97.
} 
justo somente quando recebem resultados favoráveis: a justiça procedimental precisa ser estabelecida como variável independente). ${ }^{186}$

O estudo de Tyler encontrou uma forte correlação entre o fato de o procedimento ser considerado justo (justiça procedimental) e o fato de os seus resultados também serem considerados justos (justiça distributiva), mesmo quando esses resultados não são favoráveis $^{187}$. Os procedimentos considerados justos são capazes de mitigar consideravelmente as conseqüências dos resultados desfavoráveis. Quando o procedimento é considerado justo, a forma como ele é avaliado não se torna negativa na medida em que os resultados se tornam desfavoráveis. Quando o procedimento é considerado injusto, por sua vez, a sua avaliação declina consideravelmente na medida em que os resultados se tornam desfavoráveis.

O suporte às autoridades não é afetado quando resultados desfavoráveis são produzidos por procedimentos considerados justos, já que a capacidade desses procedimentos de absorver os efeitos das decisões desfavoráveis é extremamente robusta $^{188}$. Além disso, quando uma autoridade é considerada legítima, a probabilidade de que as suas decisões sejam consideradas justas é maior. Tyler também observou que os julgamentos sobre a justiça dos procedimentos influenciam os julgamentos sobre a legitimidade das autoridades, que, por sua vez, influenciam a obediência à lei ${ }^{189}$.

Os procedimentos considerados justos são aqueles que permitem que os cidadãos apresentem os seus argumentos, sejam ouvidos e tenham o seu ponto de vista considerado $^{190}$. Não basta que sejam criadas oportunidades de fala, pois o público precisa considerar que as suas opiniões possuem influência sobre a decisão tomada ${ }^{191}$. Tyler também verificou que o público espera que as decisões sejam produzidas a partir de informações objetivas, de maneira imparcial e sem favorecimentos. Evidências de corrupção ou favorecimento podem provocar no público a sensação de que resultados

\footnotetext{
${ }^{186}$ Tom Tyler, Why People Obey the Law, pp. 93-97.

${ }^{187}$ Tom Tyler, Why People Obey the Law, pp. 93-97.

${ }^{188}$ Tom Tyler, Why People Obey the Law, p. 107.

189 Tom Tyler, Why People Obey the Law, p. 103.

${ }^{190}$ Tom Tyler, Why People Obey the Law, p. 138.

${ }^{191}$ Tom Tyler, Why People Obey the Law, p. 149.
} 
mais justos e/ou favoráveis poderiam ter sido obtidos caso o procedimento fosse isento de falhas, causando insatisfação e revolta ${ }^{192}$.

O estudo de Tyler não pretende disseminar uma confiança cega no poder dos procedimentos. Em vários momentos, o seu estudo adquire um forte tom de advertência. A capacidade dos procedimentos de absorver dissensos é limitada, mesmo quando eles são considerados justos. Se um procedimento justo produz continuamente resultados desfavoráveis, a sua correção pode ser colocada em dúvida ${ }^{193}$. A experiência do público influencia as suas expectativas cognitivas e normativas acerca da realidade política e jurídica, por isso, a sua lealdade não está assegurada em situações futuras. ${ }^{194}$ A frustração contínua das expectativas do público pode erodir a crença nas instituições democráticas, ou pelo menos a crença em tipos específicos de instituições democráticas, por mais sólidas que elas sejam.

\footnotetext{
192 Tom Tyler, Why People Obey the Law, p. 117.

193 Tom Tyler, Why People Obey the Law, p. 107.

194 Tom Tyler, Why People Obey the Law, p. 106.
} 


\section{A MODERNIDADE PERIFÉRICA.}

Eine Theorie muß Vergleichsmöglichkeiten eröffnen.

(Uma teoria deve tornar as comparações possíveis)

Niklas Luhmann

No primeiro capítulo, foi introduzida sucintamente a idéia de que a sociedade atual é composta por sistemas funcionais que obedecem cada qual à sua própria lógica. No presente capítulo, pretendemos identificar os limites dessa descrição, principalmente quando se trata de aplicá-la acriticamente a realidades distintas da realidade dos países desenvolvidos. A teoria dos sistemas de Luhmann, assim como outras teorias que versaram sobre a modernidade, como a de Marx, Durkheim, Weber e Habermas, foi construída a partir da observação da modernidade central e, por isso, não pode ser aplicada à nossa realidade sem que as devidas mediações sejam feitas.

Como o presente trabalho tem como escopo analisar o processo de legitimação do Estado Democrático de Direito na modernidade periférica a partir do caso brasileiro, nada mais natural do que responder primeiramente à seguinte pergunta: o que é a modernidade e como ela se diferencia das formas de organização social que a precederam? A partir daí, nos concentraremos na descrição do contexto brasileiro, cuja 
peculiaridade não reside propriamente na persistência de relações sociais pré-modernas, mas num processo seletivo de modernização que resultou numa sociedade profundamente desigual e excludente ${ }^{195}$.

\subsection{Modernidade e Diferenciação Funcional.}

Para que possamos descrever a especificidade do contexto brasileiro, é necessário em primeiro lugar realizar uma breve digressão sobre a transformação estrutural que deu origem à modernidade. Mais especificamente, trata-se de uma transformação radical na maneira como a sociedade distribui e organiza as suas comunicações $^{196}$. A evolução social tem sido comumente descrita como um aumento progressivo da complexidade da sociedade ${ }^{197}$. Esse processo teria culminado na sociedade moderna, portadora de um nível de complexidade jamais alcançado por nenhuma formação social que a precedeu. Na tentativa de captar a "essência" desse tipo de sociedade, as ciências sociais têm utilizado os rótulos mais diversos, como

195 Orlando VILLAS BÔAS FILHO, Teoria dos Sistemas e o Direito Brasileiro. São Paulo: Saraiva, 2009. Jessé SOUZA, A Construção Social da Subcidadania: para uma sociologia política da modernidade periférica. Belo Horizonte: Editora UFMG; Rio de Janeiro: IUPERJ, 2003. A idéia da persistência de traços sociais pré-modernos que impediriam o ingresso pleno na modernidade é constante no pensamento brasileiro e foi defendida, dentre outros, por Raymundo FAORO, na obra Os Donos do Poder: formação do patronato político brasileiro. Rio de Janeiro: Globo, 2001. Faoro descreveu a realidade brasileira a partir da dominação patrimonialista exercida por uma elite de natureza estamental (há que se ressaltar que a análise de Faoro abrange somente o período até Getúlio Vargas). Para Weber, que formulou o conceito de patrimonialismo utilizado por Faoro, trata-se de um tipo de dominação prémoderno.

${ }^{196} \mathrm{Na}$ teoria dos sistemas, a sociedade é descrita como a totalidade das comunicações. Somente na sociedade existe comunicação e não existe comunicação que ocorra fora dela. A comunicação também é o elemento constitutivo da sociedade. Uma interessante e didática explicação acerca dos motivos que levaram Luhmann - de maneira inédita - a formular a sua teoria social a partir da comunicação pode ser encontrada no artigo de Rudolph STICHWEH, "Systems Theory as an Alternative to Action Theory? The Rise of 'Communication' as a Theoretical Option". Acta Sociologica, Vol. 43, No. 1 (2000), pp. 5-13.

${ }^{197}$ A complexidade indica que existem mais possibilidades do que se pode realizar. Niklas LUHMANN, Sociologia do Direito, v. 1, p. 45. O aumento de complexidade, por sua vez, indica que mesmo que o número de possibilidades realizáveis tenha aumentado, o número de possibilidades irrealizáveis aumentou de forma ainda mais significativa. Cada escolha (seleção) exclui um número maior de alternativas. A complexidade também implica deparar-se mais freqüentemente com situações onde se realizam escolhas e, nesse sentido, significa "being forced to select; being forced to select means contingency; and contingency means risk". Niklas LUHMANN, Social Systems, p. 25. 
"sociedade do risco ${ }^{198, ", ~ " s o c i e d a d e ~ d a ~ i n f o r m a c ̧ a ̃ o ~}{ }^{199}$ ", "sociedade pós-industrial ${ }^{200 ",}$ “modernidade líquida ${ }^{201 "}$ " etc. Outros, ainda, têm descrito a sociedade hodierna a partir de uma eventual superação da modernidade e da emergência de uma "pósmodernidade ${ }^{202,}$.

Segundo Luhmann, a sociedade moderna não se diferencia das sociedades prémodernas somente pelo seu nível de complexidade, mas também pela forma como a sua complexidade está estruturada, ou seja, por um tipo específico de diferenciação ${ }^{203}$. Cada sociedade é marcada pela predominância de uma forma de diferenciação, que indica os seus limites de variação estrutural, ou seja, indica o quantum de complexidade que a sociedade pode adquirir e a maneira como essa complexidade é administrada. Habermas, da mesma forma, afirma que cada sociedade possui um princípio de organização que delimita as suas possibilidades de alteração ${ }^{204}$. Esses princípios de organização - que Luhmann chama de tipos de diferenciação social - delimitam a capacidade da sociedade de aprender sem perder a sua consistência.

Luhmann chama a atenção para o fato de que a enorme variedade de eventos e rupturas históricas contrasta intensamente com o pequeno número de formas de diferenciação encontradas ao longo da evolução social: (i) a diferenciação segmentária, (ii) a diferenciação centro-periferia, (iii) a diferenciação por estratos e (iv) a diferenciação funcional ${ }^{205}$. A diferenciação segmentária é típica de sociedades arcaicas, marcadas pelo baixo grau de complexidade. O traço fundamental dessa forma de diferenciação é a igualdade entre todos os sistemas existentes na sociedade (famílias, tribos, clãs, etc.). Cada um deles observa o mundo circundante a partir da diferença entre o que é familiar e o que não é, e as eventuais relações com os demais grupos são

198 Ulrick BECK, Risikogesellschaft: auf dem Weg in eine andere Moderne. Frankfurt am Main: Suhrkamp, 1986.

${ }^{199}$ Raimo BLOM (Ed.) (et al.), The Information Society Reader. New York: Routledge, 2001.

${ }^{200}$ Daniel BELL, The Coming of Post-Industrial Society: a venture in social forecasting. New York: Basic Books, 1976.

${ }^{201}$ Zygmunt BAUMAN, Modernidade Líquida. Tradução: Plínio Dentzien. Rio de Janeiro: Jorge Zahar, 2007.

${ }^{202}$ Jean-François LYOTARD, La Condition Postmoderne: rapport sur le savoir. Paris: Éditions de Minuit, 1979. No Brasil, Eduardo Carlos Bianca BITTAR, O Direito na Pós-modernidade (e reflexões frankfurtianas). Rio de Janeiro: Forense Universitária, 2009.

203 "La diferenciación no es outra cosa que la formación de sistemas dentro de sistemas". Niklas LUHMANN, Inclusión y Exclusión, pp. 167-195.

204 Jürgen HABERMAS, Legitimation Crisis, p. 7. Embora partam do mesmo problema, Luhmann e Habermas chegam a conclusões distintas sobre as formas de diferenciação (ou princípios de organização) da sociedade, embora concordem que a sociedade atual é uma sociedade funcionalmente diferenciada.

${ }^{205}$ Niklas LUHMANN, "Differentiation of Society". Canadian Journal of Sociology / Cahiers canadiens de sociologie, Vol. 2, No. 1 (Winter, 1977), pp. 29-53. , La Sociedad de la Sociedad, pp. 471-490. 
regidas pela reciprocidade (tanto na recompensa quanto na represália). Com a intensificação dos contatos entre os grupos e o aumento do poder de alguns deles em detrimento dos demais, no entanto, o princípio da reciprocidade cede lugar à desigualdade entre os sistemas, manifestada sob a forma de diferenciação centroperiferia ou de diferenciação por estratos.

A diferenciação centro-periferia se baseia na diferença entre a cidade e o campo. Embora essa diferenciação permita que a sociedade assimile um grau maior de complexidade, ela não é isenta de problemas: os contatos escassos entre a cidade e o campo limitam o exercício do poder, isolando o centro como uma espécie de ilha da sociedade $^{206}$. Além disso, o próprio centro começa a se diferenciar com a formação de estratos hierarquicamente desiguais. A estratificação enquanto forma de diferenciação surge quando o estrato superior já não reconhece a existência de relações de parentesco com o estrato inferior e a sociedade já não pode descrever-se como um sistema de parentesco com uma origem comum $^{207}$. Na sociedade estratificada, uma camada superior possui acesso privilegiado aos recursos da sociedade e, apesar de pequena, consegue impor-se perante a camada inferior ${ }^{208}$.

A estratificação não é a mera diferença de posições ou a assimetria no acesso aos recursos materiais ou imateriais. Ela só existe quando um sistema social se diferencia dos demais sob o ponto de vista de uma diferença de hierarquia. Além disso, ela se torna a forma de diferenciação social dominante quando os outros modos de diferenciação passam a se orientar por ela ${ }^{209}$. Através de costumes e rituais, da valorização da genealogia e de uma consciência específica, o estrato superior constrói uma semântica que o diferencia do estrato inferior. Enquanto o primeiro é altamente seletivo em questões de gosto e estilo, o segundo tem possibilidades de escolha muito mais restritas: na maioria das vezes, só a pobreza lhe resta.

$\mathrm{Na}$ Europa ocidental da Idade Média, o estrato superior da sociedade era formado pela nobreza e pelo clero, enquanto o estrato inferior era formado pelo restante da população. Ao contrário do sistema de castas na Índia, a estratificação européia não se baseou num conceito de pureza religiosamente instituído, mas na propriedade da terra

\footnotetext{
${ }^{206}$ Orlando VILLAS BÔAS FILHO, Teoria dos Sistemas e o Direito Brasileiro, pp. 102-103.

${ }^{207}$ Niklas LUHMANN, La Sociedad de la Sociedad, p. 538-539.

${ }^{208}$ Niklas LUHMANN, La Sociedad de la Sociedad, p. 539.

${ }^{209}$ Niklas LUHMANN, La Sociedad de la Sociedad, p. 543.
} 
e, posteriormente, na desigualdade de status juridicamente respaldada ${ }^{210}$. Os direitos e deveres do nobre eram bem diferentes dos direitos e deveres do servo ${ }^{211}$. Embora a lei não previsse a mudança de status, ela também não a tornava impossível, como no sistema indiano de castas. Um servo que se esforçasse podia se tornar um membro do clero, e os comerciantes ricos podiam oferecer as suas filhas em casamento e assim garantir o ingresso de membros de sua família na nobreza.

O desenvolvimento da sociedade de estratos na Europa da Idade Média criou condições propícias para a emergência da diferenciação funcional, fenômeno que marca o início da modernidade. A Igreja e as corporações de ofício se estabeleceram como precursoras das organizações modernas. A concentração de recursos na camada superior da sociedade permitiu o financiamento das artes, das ciências e das grandes navegações. Ainda no século XVI, os reformadores protestantes negaram a necessidade de mediação para acesso ao sagrado e com isso toda a hierarquia social baseada nessa idéia ${ }^{212}$. A partir desses e outros acontecimentos, a diferenciação por estratos entrou em decadência, dando lugar à distribuição das comunicações a partir do desempenho de tarefas específicas.

Os pais fundadores da sociologia já haviam identificado que o surgimento da modernidade foi marcado por uma transformação estrutural sem precedentes. Marx falou na destruição das formas tradicionais de vida e na emergência da burguesia como classe dominante; Durkheim assinalou a passagem da solidariedade mecânica para a solidariedade orgânica ${ }^{213}$, ao passo que Weber retratou a diferenciação das esferas de valor e o desencantamento do mundo, assim como a relação de mútua complementaridade entre o capitalismo e a ética protestante ${ }^{214}$. Destaca-se também a

\footnotetext{
${ }^{210}$ Niklas LUHMANN, La Sociedad de la Sociedad, p. 542. A nobreza se fechava em torno de si mesma principalmente através da endogamia. O nascimento constituía o critério de pertencimento a ela, o que não eliminava o caso dos filhos bastardos.

${ }^{211}$ Era perfeitamente normal que o crime cometido por um nobre contra um popular fosse julgado de forma bem diferente do crime cometido por um popular contra um nobre.

${ }^{212}$ Charles TAYLOR, As Fontes do Self: a construção da identidade moderna. Tradução: Adail Ubirajara Sobral e Dinah de Abreu Azevedo. São Paulo: Loyola, 1997, pp. 273-282. Para Jessé Souza, "como as gradações da maior ou menor sacralidade de certas funções são a base da hierarquia (religiosa) das sociedades tradicionais, desvalorizar a hierarquia baseada nesta ordem é retirar os fundamentos da hierarquia social como um todo". A Construção Social da Subcidadania: para uma sociologia política da modernidade periférica, p. 31.

${ }^{213}$ Émile DURKHEIM, Da Divisão do Trabalho Social. São Paulo: Martins Fontes, 1999.

${ }^{214}$ Max WEBER, Economia e Sociedade. A Ética Protestante e o Espírito do Capitalismo. São Paulo: Martin Claret, 2002.
} 
obra de Karl Polanyi, que analisou o traumático surgimento da economia de mercado através da figura do "moinho satânico". 215

Segundo Claus Offe, o surgimento da modernidade na Europa pode ser compreendido a partir da interseção de dois processos que se auto-reforçam:

Um processo consiste no desacoplamento de atores, organizações e subsistemas sociais em relação a outros sistemas: um processo que é documentado de maneira unânime na literatura teórica por meio de conceitos como individuação, emancipação, separação, autonomização, auto-governança, "desenraizamento" (disembeddedness), etc. O outro processo consiste no declínio dos cometimentos, rotinas, facticidades e expectativas tradicionais. A ação autonomizada se torna irrestrita e desvinculada, "insaciável" (como Marx afirma n'O Capital) na busca e expansão dos seus próprios valores particulares ${ }^{216}$.

Na sociedade feudal, o mesmo tipo de comunicação era produzido por esferas sociais distintas, sem que disso resultassem consequiências desintegradoras, pois a ordem era garantida pela supremacia de um estrato sobre o outro ${ }^{217}$. Numa mesma localidade coexistiam diversas moedas, emitidas por fontes distintas. No plano político, a inexistência de um Estado soberano e estruturado organizacionalmente permitia que decisões coletivamente vinculantes fossem produzidas pelo império, por senhores feudais, pela Igreja e por outros poderes locais.

$\mathrm{Na}$ sociedade diferenciada por funções, por outro lado, cada sistema funcional adquire em caráter universal o monopólio de uma comunicação específica. Isso ocorre a partir do momento em que as dificuldades de coordenação no feudalismo se acentuam e a sociedade renuncia à multifuncionalidade e à coordenação dos sistemas entre si em prol da coordenação dos sistemas em si. Determinadas soluções para problemas sociais específicos se repetem a ponto de gerar a estabilização de estruturas, e a distinção entre a nobreza e o povo se desvaloriza gradualmente, culminando na igualdade jurídica

\footnotetext{
${ }^{215}$ Karl POLANYI, The great transformation: the political and economic origins of our time. Boston: Beacon Press, 2001.

${ }^{216}$ Claus OFFE, "The Utopia of the Zero-Option: modernity and modernization as normative political criteria”. Praxis International, Issue 1, 1987, p. 3 (tradução livre).

${ }^{217}$ Niklas LUHMANN, La Sociedad de la Sociedad, p. 562.
} 
formal típica do Estado Democrático de Direito. A estratificação enquanto forma primária de diferenciação cede lugar à diferenciação funcional.

Cada sistema funcional regula por si só os temas de que trata, as regras com as quais se comunica e com isto a posição que atribui às pessoas. Nisso desempenham um papel importante tanto as generalizações independentes dos estratos (por exemplo, a capacidade jurídica geral, a nacionalidade, a maturidade depois de freqüentar as escolas superiores), como distinções dependentes dos estratos. As primeiras configuram novas assimetrias de papéis e colocam em proeminência as assimetrias antigas: governantes/governados (relativa ao Estado e não a uma posição social); produtor/consumidor; professor/aluno; médico/paciente. Naturalmente o acesso a esses papéis segue dependendo dos estratos, ainda que ao mesmo tempo as novas assimetrias deslegitimem a antiga ordem estamental e mostrem dessa forma que a sociedade realizou uma transformação profunda ao passar do primado da estratificação a uma ordem diferenciada por funções ${ }^{218}$.

O estabelecimento da diferenciação funcional representou a última transformação estrutural significativa ocorrida na sociedade. Pelo menos desde o final do século XVIII, o sistema jurídico é marcado pelo direito positivo, a política pela preponderância dos Estados Nacionais, a economia pelo modo de produção capitalista e a ciência por pesquisas conduzidas por institutos autônomos, independentemente da vasta literatura sobre a suposta crise desses paradigmas. Não existem evidências estruturais de uma ruptura com a modernidade e da emergência de uma pós-modernidade ${ }^{219}$.

A defesa da pós-modernidade ocorre muitas vezes no plano semântico, por meio do discurso de "falência do projeto da modernidade", como se a modernidade fosse apenas um conjunto de idéias, e não uma condição estrutural. Esse discurso não é capaz de apontar a existência de transformações estruturais significativas que já não estejam em curso há alguns séculos, como a diferenciação das esferas de valor, a erosão dos universalismos, a globalização e o avanço tecnológico. O discurso pós-moderno, portanto, deve ser compreendido como uma tentativa de atualização da semântica

\footnotetext{
${ }^{218}$ Niklas LUHMANN, La Sociedad de la Sociedad, p. 585. (Tradução livre).

${ }^{219}$ Niklas LUHMANN, "Why Does Society Describes Itself as Postmodern?" Cultural Critique, No. 30, The Politics of Systems and Environments, Part I (Spring, 1995), pp. 171-186. posmodernidad, in , La Sociedad de la Sociedad, pp. 905-910.
} 
através da qual a sociedade descreve a si mesma, a partir do reconhecimento do aprofundamento da diferenciação funcional e da mundialização ${ }^{220}$.

\subsection{Modernidade Central e Modernidade Periférica.}

No tópico anterior, procuramos compreender o surgimento da modernidade como passagem da sociedade de estratos para a sociedade diferenciada por funções. Segundo a teoria dos sistemas, a modernidade se caracteriza pela emergência de sistemas funcionais autônomos ou, nas palavras de Teubner, "de racionalidades que, apesar de particularistas e auto centradas, são socialmente abrangentes e demandam aceitação universal". ${ }^{221}$ Cada sistema funcional possui abrangência global, o que significa que existe apenas um sistema econômico, um sistema científico, um sistema político e assim por diante.

A atual sociedade também pode ser descrita como sociedade mundial (Weltgesellschaft), já que a distância entre localidades deixou de ser uma barreira relevante para a comunicação ${ }^{222}$. O mundo globalizado é marcado pela integração comunicativa e pela interdependência ${ }^{223}$. As desigualdades entre as regiões do planeta não podem mais ser compreendidas somente a partir de fatores locais e endógenos, pois são influenciadas por processos que ocorrem em escala global (pensemos no exemplo das crises econômicas).

A sociologia, portanto, deve "partir do pressuposto de uma sociedade mundial e então investigar como e porque essa sociedade tende a manter ou até mesmo aumentar as desigualdades regionais ${ }^{224}$ ". A teoria dos sistemas, dentro dessa idéia, formula um novo programa de estudos comparativos, onde as diferenças regionais podem ser observadas como diferenças na implantação da lógica funcional e no desempenho

\footnotetext{
${ }^{220}$ Niklas LUHMANN, "Why Does Society Describes Itself as Postmodern?”.

${ }^{221}$ Gunther TEUBNER, “Altera Pars Audiatur”, p. 150.

222 Niklas LUHMANN, "Globalization or World Society: How to Conceive of Modern Society?" International Review of Sociology Mar 97, Vol. 7 Issue 1, pp. 67-80. David SEIDL, "The Basic Concepts of Luhmann's Theory of Social Systems", p. 35.

${ }^{223}$ Nesse sentido, as considerações feitas no primeiro capítulo sobre os meios de comunicação de massa.

${ }^{224}$ Niklas LUHMANN, “Globalization or World Society: How to Conceive of Modern Society?", p.77.
} 
alcançado pelos sistemas funcionais. A sua natureza funcional-estruturalista permite comparar entre si, como equivalentes funcionais, resultados que sob outra perspectiva seriam absolutamente incomparáveis ${ }^{225}$.

Esse método, no entanto, não é isento de críticas. Segundo Orlando Villas Bôas Filho, comparar localidades altamente heterogêneas a partir da implantação da lógica funcional implica conceder à diferenciação funcional um status normativo ${ }^{226}$. Além disso, esse tipo de comparação desconsideraria as nuances e peculiaridades inerentes a cada processo histórico, pois em cada localidade a modernização ocorreu de maneira seletiva, e nenhuma delas representa a concretização típico-ideal dos ideais da modernidade. Não existe uma única linha de desenvolvimento para os sistemas funcionais, que operam a partir das precondições que lhes são dadas em termos de estrutura $^{227}$.

As advertências de Orlando Villas Bôas Filho sobre o perigo dos reducionismos analíticos são extremamente relevantes, embora algumas considerações precisem ser tecidas acerca das suas críticas. Em primeiro lugar, adotar o método da comparação funcional não implica necessariamente emitir juízos de valor sobre a diferenciação funcional, pois os objetivos da análise são eminentemente descritivos. A abordagem sociológica não se preocupa em avaliar a diferenciação funcional sob um ponto de vista interno e muito menos em prescrever que os sistemas funcionais devem operar de maneira autônoma. A sua preocupação reside muito mais em observar como a diferenciação funcional se relaciona com o problema a ser analisado. Mais do que uma solução para os problemas da sociedade, a autonomia dos códigos funcionais da linguagem (ter/não-ter, governo/oposição, lícito/ilícito, etc.) também produz novos problemas que demandam tratamento, como o déficit de coordenação entre as distintas lógicas funcionais, identificado por Offe e Peruzzotti ${ }^{228}$.

\footnotetext{
225 Darío RODRÍGUES MANSILLA, Nota a La Versión en Español, in Niklas LUHMANN, Organización y decisión.

${ }^{226}$ Orlando VILLAS BÔAS FILHO, Teoria dos Sistemas e o Direito Brasileiro, p. 277-278.

${ }^{227}$ Orlando VILLAS BÔAS FILHO, Teoria dos Sistemas e o Direito Brasileiro, pp. 328-329.

${ }^{228}$ Claus OFFE, "The Utopia of the Zero-Option: modernity and modernization as normative political criteria". Enrique PERUZZOTTI, "Modernization and Juridification in Latin America: A Reassessment of the Latin American Developmental Path". Thesis Eleven, 1999, 58, pp. 59-82. Segundo Peruzzotti, "the progressive institutional differentiation that results from modernization poses coordination and compatibility problems among the logics of conflicting societal subsystems".
} 
Em segundo lugar, adotar o método da comparação funcional não implica necessariamente desconsiderar as especificidades do contexto brasileiro e alçar o processo europeu de modernização à condição de padrão normativo, desconsiderando que ele também é um processo seletivo e que não representa a única via de acesso à modernidade. A comparação funcional se faz necessária justamente para a melhor compreensão da realidade brasileira e do seu posicionamento na sociedade mundial. Afirmar que existe um déficit de desempenho dos sistemas funcionais no Brasil implica, mesmo que sub-repticiamente, fazer uso de parâmetros comparativos e afirmar que existem localidades onde esse déficit não ocorre, o que, por sua vez, pressupõe a existência de processos sociais funcionalmente comparáveis.

Vejamos o exemplo do direito, que Orlando Villas Bôas Filho analisa em sua obra. A teoria dos sistemas parte do pressuposto de que existe apenas um sistema jurídico, presente tanto no Brasil quanto nos países centrais. Os limites territoriais dos países indicam apenas os limites de atuação das organizações judiciárias (que são as partes centrais do sistema), e não os limites do sistema. Obviamente, as diferenças entre o Brasil e os países centrais existem e são relevantes, já que os sistemas funcionais são altamente dependentes da história e nivelam as suas operações a partir das condições estruturais existentes no plano local ${ }^{229}$.

Analisar processos funcionalmente equivalentes, entretanto, significa buscar a unidade das diferenças. A função desempenhada pelo sistema jurídico no Brasil e nos países centrais é a mesma: a estabilização de expectativas normativas. As organizações judiciárias de ambos os locais são estruturadas com vistas ao desempenho dessa função. O código (lícito-ilícito) e os acoplamentos estruturais do sistema jurídico são os mesmos. Embora estejamos falando de ordenamentos jurídicos distintos, existem princípios, regras, precedentes e construções doutrinárias análogas ${ }^{230}$. Além disso, existe a tendência a uma crescente troca de aprendizado entre ordens jurídicas $\operatorname{distintas}^{231}$.

A seguinte afirmação de Celso Campilongo exemplifica, de maneira clara, como o método de comparação funcional que trabalha com o esquema centro/periferia deve

\footnotetext{
${ }^{229}$ Niklas LUHMANN, Law as a Social System, p. 490.

${ }^{230}$ Principalmente se compararmos o Brasil a países de tradição romano-germânica que foram e são altamente influentes na práxis jurídica brasileira, como Portugal, Alemanha, Itália e França.

${ }^{231}$ Marcelo NEVES, Transconstitucionalismo.
} 
proceder em relação ao sistema jurídico, perguntando justamente pelas suas especificidades operativas na realidade periférica:

[...] o sistema jurídico, no Brasil, é operativamente fechado e funciona de modo similar aos sistemas jurídicos aos sistemas jurídicos dos países economicamente centrais. Apesar disso, inegavelmente, mesmo sendo um sistema autônomo e separado dos demais sistemas funcionais, opera num ambiente significativamente diverso. O tipo de operação de observação que o sistema jurídico brasileiro faz dos sistemas demais sistemas e o código de organização de suas operações é fundamentalmente idêntico ao dos demais sistemas jurídicos autopoiéticos. Onde residem as diferenças ${ }^{232}$ ?

Se não pudéssemos analisar processos funcionais e prestacionais de um mesmo sistema funcional em localidades distintas como funcionalmente equivalentes, melhor seria abandonar não só o método funcional-estruturalista como a própria pretensão de uma teoria social abrangente. Nesse caso, como propôs Merton, deveríamos nos conformar com as teorias de médio alcance (middle range theories ${ }^{233}$ ). Não existe no método da comparação funcional nenhuma tendência intrínseca à produção de "simplificações e esquematizações que levam, invariavelmente, a distorções analíticas $^{234 ",}$.

Luhmann é claro a esse respeito:

Os instrumentos conceituais de uma teoria da sociedade enfrentam a tarefa de elevar o seu próprio potencial de complexidade: interpretar os fatos mais heterogêneos com os mesmos conceitos e, por conseguinte, garantir a possibilidade de comparar entre si

${ }^{232}$ Celso Fernandes CAMPILONGO, “A Posição dos Tribunais no Centro e na Periferia do Sistema Mundial”. In Fernando Castañeda SABIDO e Angélica Cuéllar VÁZQUEZ (Coord.), Redes de Inclusión: la construcción social de la autoridad. México: Facultad de Ciencias Políticas y Sociales; UNAM; Miguel Ángel PORRÚA, 1998, p. 63. Embora o sistema jurídico no Brasil seja autopoiético, não negamos a existência de "momentos de alopoiesis", nos quais o código jurídico é sobreposto pelo código de outros sistemas funcionais ou por redes sociais "parasitárias", conforme sugestão de Marcelo Neves. A título de precisão terminológica, utilizamos a expressão "sistema jurídico" sempre no singular, pois se trata de apenas um sistema que se segmenta territorialmente. O mesmo é válido para os demais sistemas funcionais (economia, política, religião, mídia, etc.).

${ }^{233}$ Robert MERTON, Sociologia: Teoria e Estrutura. Tradução de Miguel Maillet. São Paulo: Mestre Jou, 1970, pp. 51-83.

${ }^{234}$ Orlando VILLAS BÔAS FILHO, Teoria dos Sistemas e o Direito Brasileiro, p. XXV. 
contextos relacionais muito diversos. Esta intenção de tratar o extremamente diverso como algo comparável é acolhida pelo método de comparação funcional ${ }^{235}$.

As desigualdades regionais indicam, dentre outras coisas, que a diferenciação funcional não se afirmou como forma primária de diferenciação em todas as partes do globo e que fatores históricos podem atuar como impulsionadores ou dificultadores da autonomia dos sistemas funcionais ${ }^{236}$. Além disso, os sistemas funcionais alcançam desempenhos distintos em diferentes localidades: em algumas delas, o sistema político pode encontrar dificuldades maiores para produzir decisões e torná-las coletivamente vinculantes e o sistema jurídico pode encontrar dificuldades maiores para generalizar expectativas normativas de maneira congruente.

São exatamente essas assimetrias que produziram na sociedade atual uma diferenciação entre um centro desenvolvido e uma periferia subdesenvolvida, entre uma modernidade central e uma modernidade periférica. Essa nova forma de diferenciação centro-periferia não se confunde com a diferenciação segmentária das sociedades prémodernas ou com a diferenciação centro-periferia no interior de um sistema funcional específico (o sistema político, por exemplo, possui o Estado como centro e diversas organizações não estatais como periferia). ${ }^{237}$ Ela também não possui conotações normativas, como na teoria da dependência e na teoria da exploração, e nem se baseia no conceito de sistema mundial como economia mundial capitalista de Wallerstein ${ }^{238}$.

São motivos políticos que fazem com que a segmentação regional do sistema político da sociedade mundial em Estados se mantenha apesar do permanente risco de guerra, e são motivos econômicos que forçam uma diferenciação entre centro e periferia, entre regiões altamente desenvolvidas e regiões carentes de desenvolvimento ${ }^{239}$.

\footnotetext{
${ }^{235}$ Niklas LUHMANN, La Sociedad de la Sociedad, p. 26. (tradução livre)

236 “....] Las condiciones locales pueden contribuir o limitar el establecimiento de lógica funcional total o parcialmente. Es justamente ahí, en el ámbito de la investigación empírica, donde el espacio (nacional, regional, local, etc.) vuelve a hacerse relevante". Jorge Galindo MONTEAGUDO, "La Teoría Sistémica de Niklas Luhmann: Alcances e Limites", p. XL.

${ }^{237}$ Marcelo NEVES, "Die Staaten im Zentrum und die Staaten an der Peripherie”, p. 249.

${ }^{238}$ Marcelo NEVES, "Die Staaten im Zentrum und die Staaten an der Peripherie, p. 249.

${ }^{239}$ Niklas LUHMANN, Ökologische Kommunikation: kann die moderne Gesellschaft sich auf ökologishe Gefährdungen einstellen? Wiesbaden: Verlag für Sozialwissenschaften, 2008, p. 168. (tradução livre).
} 
A divisão centro-periferia possui fundamentos econômicos, em razão do primado que o código econômico (ter-não ter) possui na sociedade atual, e pressupõe a segmentação territorial do sistema político e do sistema jurídico em Estados. Esse primado não significa que o sistema econômico determine diretamente a operação dos demais sistemas funcionais, já que a diferenciação funcional pressupõe horizontalidade entre eles. Um sistema não pode interferir diretamente no funcionamento de outro sem provocar resultados desdiferenciadores. Além disso, na sociedade altamente complexa do presente, tornou-se uma exigência normativa que os códigos e programas de um sistema não se imponham diretamente aos demais ${ }^{240}$.

O primado estrutural do código econômico indica somente que, numa sociedade mercantilizada, o problema da escassez é cada vez mais constante. A escassez torna-se a condição de possibilidade das condições de possibilidade, a fórmula de contingência das fórmulas de contingência. Num mundo onde os sistemas limitam o desenvolvimento uns dos outros, a escassez de recursos torna-se a mais relevante condição limitadora ${ }^{241}$. Obviamente, se um sistema funcional não consegue se imunizar frente ao código econômico, a força deste passará a determinar diretamente a operação do sistema invadido, colocando em risco a sua autonomia operacional.

Nos ambientes dos diversos sistemas parciais da sociedade mundial (moderna) a economia (associada à técnica e à dimensão da ciência a esta vinculada) constitui o mais relevante fator, a ser observado primariamente. A economia está equipada com o mais forte código binário entre um "sim" e um "não", a saber, a diferença entre "ter" e "nãoter". Em alguns casos, especialmente nas situações em que há enormes desigualdades e ampla exclusão relativamente ao sistema econômico, esse primado pode levar a experiências de desdiferenciação economicamente condicionada no âmbito da sociedade mundial ${ }^{242}$.

\footnotetext{
${ }^{240}$ Marcelo NEVES, "E se Faltar o Décimo Segundo Camelo? Do direito expropriador ao direito" invadido. In: André-Jean ARNAUD e Dalmir LOPES JR, Niklas Luhmann: do sistema social à sociologia jurídica. Tradução de Dalmir Lopes Jr; Daniele Andréa da Silva Manão e Flávio Elias Riche. Rio de Janeiro: Lumen Juris, 2004, pp. 167-168. No mesmo sentido, Gunther TEUBNER, Altera Pars Audiatur. Constatar a existência dessas exigências normativas não implica emitir juízos valorativos a respeito delas.

${ }^{241}$ A integração social é justamente a limitação do grau de liberdade dos sistemas funcionais por fatores sociais e extra-sociais. Niklas LUHMANN, La Sociedad de la Sociedad, p. 478.

${ }^{242}$ Marcelo NEVES, Transconstitucionalismo, p. 25.
} 
A diferenciação centro-periferia é capitaneada por fatores econômicos e distribuída a partir da segmentação da política e do direito em Estados (dentro de um mesmo país, por sua vez, podem existir regiões mais desenvolvidas e regiões menos desenvolvidas). O crescimento econômico permanece dependente da estrutura regional $^{243}$ e, ao mesmo tempo, é fortemente influenciado por processos que ocorrem em escala global e que, por serem macrossociais, transcendem a simples intencionalidade das interações. Plano regional e plano mundial, dessa forma, se somam na moldagem de uma sociedade crescentemente "absorvida" pelas organizações e pelos sistemas funcionais ${ }^{244}$.

Esse panorama traz novos contornos à problemática da exclusão social, fundamentalmente distintos daqueles existentes nas formações sociais pré-modernas. $\mathrm{Na}$ sociedade estratificada, por exemplo, estar incluído num estrato implicava estar excluído de outro, e vice-versa ${ }^{245}$. Não era possível pertencer a dois estratos ao mesmo tempo. A sociedade funcionalmente diferenciada, por outro lado, renuncia a uma regulação uniforme da inclusão: cada sistema social inclui e exclui à sua própria maneira ${ }^{246}$. Enquanto o estar incluído em um sistema funcional não implica estar incluído nos demais, "a exclusão de um sistema funcional implica, quase automaticamente, a exclusão de outros ${ }^{247}$ ". A exclusão é caracterizada por uma forte integração entre os sistemas funcionais, o que resulta numa espécie de exclusão em cadeia $^{248}$.

Quem não tem documentação, por exemplo, não pode receber prestações assistenciais do Estado, votar ou casar-se legalmente. Na Índia, quem vive na rua e não possui endereço fixo não pode matricular os filhos na escola ${ }^{249}$. No Brasil, os analfabetos - ou seja, aqueles que não obtiveram acesso ao sistema educacional encontravam-se alijados da cidadania eleitoral passiva (não podiam votar) até a Emenda

\footnotetext{
${ }^{243}$ A sociologia econômica, a partir de marcos teóricos distintos, tem ressaltado a importância dos fatores locais na promoção do desenvolvimento econômico, principalmente os chamados laços sociais fracos. Acerca disso: Mark GRANOVETTER, "The Impact of Social Structure on Economic Outcomes". Journal of Economic Perspective, Volume 19, Number 1 (Winter 2005), pp. 33-50.

"Economic Action and Social Structure: The Problem of Embeddeness". American Journal of Sociology, Volume 91, Issue 3 (Nov., 1985), pp. 481-510.

244 Sobre a idéia de absorção da sociedade pelas organizações: Charles PERROW, "A Society of Organizations". Theory and Society, Vol. 20, No. 6 (Dec., 1991), pp. 725-762.

${ }^{245}$ Niklas LUHMANN, Inclusión y Exclusión, pp. 173.174.

${ }^{246}$ Niklas LUHMANN, Inclusión y Exclusión, p. 176.

${ }^{247}$ Niklas LUHMANN, Inclusión y Exclusión, p. 190.

${ }^{248}$ Orlando VILLAS BÔAS FILHO, Teoria dos Sistemas e o Direito Brasileiro, p. 349.

${ }^{249}$ Niklas LUHMANN, Inclusión y Exclusión, pp. 190-191.
} 
Constitucional $n^{\circ} 25$ de 1985, e ainda não possuem cidadania eleitoral ativa (não podem se candidatar ${ }^{250}$ ). Os diplomas e certificados emitidos pelo sistema educacional, por sua vez, constituem pré-requisitos para o acesso a determinados postos de trabalho ${ }^{251}$.

Embora os exemplos de exclusão em cadeia possam variar de localidade para localidade, é possível observar que eles se inserem no contexto de primado do código econômico na atualidade. A exclusão do sistema econômico é a mais apta a desencadear exclusões em outros âmbitos funcionais: quem não possui propriedade e renda tem muito mais chances de estar subincluído ou excluído da educação, da saúde, da arte e da informação e entretenimento produzidos pela mídia. Da mesma forma, aumenta a probabilidade de acesso precarizado aos tribunais e à participação política ${ }^{252}$.

Não existem indícios de que os atuais níveis de exclusão possam ocasionar o colapso dos sistemas funcionais, já que a sua autopoiesis é deveras robusta. Existem apenas indícios de que eles estão mais atentos à sua incapacidade de satisfazer as suas $\operatorname{aspirações~inclusivas~}^{253}$. Altos índices de exclusão constituem obstáculos à operação dos sistemas funcionais, seja porque produzem indiferença em relação a determinados $\operatorname{códigos}^{254}$, engendram estruturas sociais que parasitam os recursos sistêmicos ${ }^{255}$ ou facilitam intrusões desdiferenciadoras de um sistema sobre outro.

Essas situações ocorrem com mais intensidade na modernidade periférica. Segundo Marcelo Neves, a modernidade periférica se caracteriza pela insuficiente

${ }^{250}$ Ver o art. 14 da Constituição Brasileira de 1988. Isso não implica que o sistema educacional determina diretamente a inclusão no sistema político, já que a decisão de não permitir o voto dos analfabetos é uma decisão política, ou seja, trata-se da inclusão no sistema político sendo regulada pelo próprio sistema político.

${ }^{251}$ Sobre a relação entre a inclusão no sistema educacional e a inclusão no sistema econômico, a seguinte afirmação de José Eduardo Faria: "[...] os trabalhadores menos qualificados, ou seja, aqueles com baixo grau de escolaridade, curta experiência de ensinamento, de aprendizagem e de treinamento e absoluta incapacidade tanto de operar sistemas produtivos informatizados quanto de supervisionar conjuntos de equipamentos integrados, cada vez mais vêem o layoff (demissão) converter-se em cast-off (expulsão), na medida em que tendem a ser jogados para fora do sistema produtivo, banidos da economia formal e inexoravelmente condenados ao desemprego crônico ou estrutural". O Direito na Economia Globalizada. São Paulo: Malheiros, 1999, p. 238.

${ }^{252}$ Sobre a relação entre renda e participação política no Brasil, existem evidências empíricas claras. Natália BUENO e Francisco FIALHO, "Raça, Desigualdade e Participação Política na Região Metropolitana de Belo Horizonte". In 27th Annual ILASSA Conference on Latin America, 2007, Austin. Lanic Etext collection, 2007.

${ }^{253}$ Niklas LUHMANN, Inclusión y Exclusión, p. 192.

254 "La penuria produce una gran indiferencia ante el codigo juridico legal/ilegal (lo que tiene que ser interpretado como indiferencia y no, por ejemplo, como predilección por la criminalidad)". Niklas LUHMANN, Inclusión y Exclusión, p. 191. No mesmo sentido, Orlando VILLAS BÔAS FILHO, Teoria dos Sistemas e o Direito Brasileiro, p. 351 e ss.

${ }^{255}$ Que se manifesta naquilo que Marcelo Neves chama de sobreinclusão. Ver também as observações de Luhmann sobre as redes sociais de favores em Inclusión y Exclusión, p. 182 e ss. 
inclusão dos cidadãos nos sistemas funcionais ${ }^{256}$. Em termos econômicos, trata-se da generalização do desemprego e do subemprego, e em termos político-jurídicos, da insuficiente realização dos direitos fundamentais como instituição de inclusão social ${ }^{257}$. Na modernidade central, por outro lado, o processo de modernização resultou numa maior inclusão da população nos sistemas funcionais e numa maior realização dos direitos fundamentais, embora atualmente possam ser identificadas paradoxais tendências de periferização nessas localidades ${ }^{258}$. Os imigrantes, oriundos na sua maioria de países periféricos, podem ser considerados as maiores vítimas da periferização parcial dos países centrais.

Embora na modernidade periférica tenha havido a passagem da estratificação para a diferenciação funcional (caso contrário, ela não seria parte da modernidade), ela é marcada pela insuficiente realização da lógica funcional, incapaz de se impor perante uma realidade extremamente adversa ${ }^{259}$. Segundo Enrique Peruzzotti, as patologias dos países latino-americanos não são resultantes da autonomização dos sistemas funcionais ou da erosão da esfera normativa responsável pela integração social, mas de um déficit sistêmico existente na região, claramente exemplificado pelas dificuldades que muitos desses países encontram para estabelecer uma economia de mercado e um Estado Democrático de Direito fortes ${ }^{260}$.

Esse déficit sistêmico se manifesta através de relações potencialmente destrutivas entre os sistemas funcionais e de bloqueios parciais à autopoiesis do sistema político e do sistema jurídico. Como será visto no tópico seguinte, ao menos no caso brasileiro essa realidade não pode ser considerada fruto da persistência de formas prémodernas de dominação, como o patriarcalismo. Ela é uma conseqüência do próprio processo brasileiro de modernização, que se iniciou a partir de condições estruturais bem distintas das existentes no feudalismo europeu.

\footnotetext{
${ }^{256}$ Marcelo NEVES, "Die Staaten im Zentrum und die Staaten an der Peripherie”, p. 250.

${ }^{257}$ Marcelo NEVES, "Die Staaten im Zentrum und die Staaten an der Peripherie", p. 257. Segundo o Boletim Políticas Sociais $\mathrm{n}^{\mathrm{o}} 13$ do Ipea, (2007, p. 8, disponível [on line] em http://www.ipea.gov.br/sites/000/2/publicacoes/bpsociais/bps_13/BPS_13_completo.pdf), "o capitalismo aqui instalado e a atuação regulatória do Estado no campo trabalhista não lograram universalizar o fenômeno do assalariamento formal, tornando incompleto o "processo civilizatório" de um capitalismo minimamente organizado, tal qual levado a cabo nas experiências dos países europeus ocidentais".

${ }^{258}$ Marcelo NEVES, A Constitucionalização Simbólica, p. 191 e ss. _—_ Entre Têmis e Leviatã: uma relação difícil, p. 272 e ss. ___ _Die Staaten im Zentrum und die Staaten an der Peripherie", p. 249.

${ }^{259}$ Marcelo NEVES, "Die Staaten im Zentrum und die Staaten an der Peripherie”, pp. 249-250.

${ }^{260}$ Enrique PERUZZOTTI, "Modernization and Juridification in Latin America: A Reassessment of the Latin American Developmental Path", p. 67.
} 


\subsection{A Realidade Brasileira como Realidade Periférica.}

A modernidade periférica não constitui um todo homogêneo, mas um plexo de localidades altamente heterogêneas. Segundo Jessé Souza, é possível falar numa velha periferia e numa nova periferia. A velha periferia é formada pelas grandes civilizações ou religiões orientais (budismo, confucionismo, taoísmo e hinduísmo ${ }^{261}$ ), enquanto a nova periferia é formada pelos países que se modernizaram sem o pano de fundo de uma moral conteudística generalizada. Tanto na velha periferia quanto nos países do núcleo do racionalismo ocidental (EUA, Inglaterra, Alemanha e França) houve a formação de uma esfera moral e simbólica de fundo religioso, autônoma em relação às esferas profanas, e que perpassava todas as esferas da vida, legitimando-as e conferindolhes permanência ${ }^{262}$.

Nos países da nova periferia, por outro lado, essa visão de mundo institucional e simbolicamente articulada jamais existiu. No Brasil (que faz parte da nova periferia), a religião jamais se converteu em uma esfera moral autônoma.

A religiosidade ética, cujos portadores eram os missionários jesuítas, teve eficácia localizada e transitória, nos enclaves dedicados à conversão do gentio. De resto, a capela era mero prolongamento do poder do senhor de terras e escravos e amesquinhou-se numa religiosidade mágica de cunho familiar aos antepassados. A legitimação das relações hierárquicas e desiguais era conseguida a custo da violência física aberta, no pior dos casos, ou da violência psíquica e encoberta da cooptação implícita na relação de dependência pessoal, noutros $\operatorname{casos}^{263}$.

Na Europa ocidental, na América do Norte e na Austrália, a esfera moral autônoma de fundo religioso foi responsável por impulsionar o processo de modernização, fazendo erodir o tradicionalismo econômico - expresso na ética católica

\footnotetext{
${ }^{261}$ Jessé SOUZA, A Construção Social da Subcidadania, p. 96.

${ }^{262}$ Jessé SOUZA, A Construção Social da Subcidadania, p. 96.

263 Jessé SOUZA, A Construção Social da Subcidadania, p. 97. No mesmo sentido, a análise de Maria Sylvia de Carvalho Franco, para quem a exclusão social de grande parcela da população brasileira impediu "que se constituíssem e operassem formas estáveis e duradouras de controle social, baseadas na tradição”. Homens Livres na Ordem Escravocrata. São Paulo: Kairós, 1983, p. 57.
} 
de não acumulação e de proibição da usura - e deslegitimando as hierarquias até então naturalizadas. Na velha periferia, a esfera moral autônoma foi responsável por bloquear os impulsos modernizadores: a Índia e a China, por exemplo, só se modernizaram na segunda metade do século XX. Já na nova periferia, como essa esfera moral autônoma não estava presente, inexistiram tanto o potencial generalizador, abrangente e inclusivo das sociedades centrais do ocidente quanto as profundas barreiras ao capitalismo que Weber identificou em partes do oriente ${ }^{264}$.

O processo brasileiro de modernização, portanto, foi marcado por especificidades inexistentes tanto na modernidade central quanto na velha periferia. $\mathrm{Na}$ Europa, o surgimento do capitalismo foi acompanhado de um contexto ideacional moral, religioso e cognitivo propício à generalização de um patamar de igualdade infra e ultrajurídico ${ }^{265}$. Houve correspondência entre a semântica liberal de inclusão e as transformações estruturais ocorridas nesse período ${ }^{266}$. No Brasil, por outro lado, o capitalismo e as suas práticas institucionais correlatas foram implantados "de fora para dentro", com a ajuda de uma ideologia meramente pragmática e a posteriori, que teria funcionado como uma espécie de "graxa simbólica", permitindo a introdução de idéias econômicas e políticas liberais num contexto até então patrimonialista e escravista ${ }^{267}$.

A escravidão representou a única instituição que perdurou por quase quatrocentos anos em nosso país, abrangendo a totalidade do território ${ }^{268}$. Além de ter sido responsável pela manutenção da unidade territorial brasileira, articulada em torno dos interesses escravistas, a escravidão produziu um vasto contingente de subcidadãos que jamais foram incluídos nos processos funcionais da sociedade. A abolição não foi seguida de uma política de inclusão da população negra, que permaneceu alijada do processo produtivo, da educação formal e da participação política. Isso explica porque a

\footnotetext{
${ }^{264}$ Jessé SOUZA, A Construção Social da Subcidadania, p. 100.

265 Jessé SOUZA, A Construção Social da Subcidadania, pp. 184-185.

${ }^{266}$ Segundo Luhmann, a sociedade é formada pelo plano semântico, onde ocorrem condensações de sentido temporalmente vinculantes e descrições que a sociedade faz de si mesma, e o plano estrutural, representado pelas expectativas cognitivas e normativas e por outras formas de seletividade conectiva entre comunicações. Embora o plano semântico e o plano estrutural não sejam necessariamente sincrônicos, as transformações estruturais produzem pressões para a atualização semântica das autodescrições. Ao mesmo tempo, as transformações estruturais partem das condensações de sentido existentes no plano semântico.

${ }^{267}$ Jessé SOUZA, A Construção Social da Subcidadania, pp. 184-185.

${ }^{268}$ Jessé SOUZA, A Construção Social da Subcidadania, p. 103.
} 
desigualdade social no Brasil ainda possui um forte componente racial ${ }^{269}$. Partindo das metáforas utilizadas por Gilberto Freyre é possível afirmar que o binômio casa grande/senzala encontrou correspondência no Brasil pós-escravocrata no binômio sobrado/mucambo e posteriormente no binômio bairro burguês/favela.

O Brasil colonial e imperial também foi marcado pela figura do "agregado" ou "dependente", que formava um grupo intermediário entre o senhor proprietário e o escravo obrigado ao trabalho forçado ${ }^{270}$. O agregado era um despossuído formalmente livre e a rigor dispensável, pois não exercia os papéis fundamentais da sociedade e sobrevivia nos interstícios e ocupações marginais da ordem produtiva. Assim como o escravo, esse tipo humano encontrava-se espalhado por todo o território brasileiro e representava cerca de dois terços da população no século $\mathrm{XIX}^{271}$.

$\mathrm{Na}$ ordem econômica colonial e imperial, a atividade produtiva principal era desempenhada pelos escravos. O dependente livre, por conta disso, era obrigado a ocupar as franjas e os interstícios da atividade produtiva, realizando trabalhos considerados menos importantes. Isso acabou produzindo uma relação de dependência objetiva em relação ao senhor de terras, que só na superfície assemelhava-se a um acordo voluntário. A idéia de que esses homens eram livres simplesmente por não serem escravos, portanto, seria para Jessé Souza uma "ilusão subjetiva ${ }^{272, "}$

Escravos e dependentes formalmente livres se assemelhavam pelo fechamento do horizonte de percepção dos seus próprios interesses e pela subordinação aos interesses do senhor, como se esta fosse uma escolha autônoma e consciente ${ }^{273}$. Ambos irão formar a "ralé" dos imprestáveis e inadaptados ao novo sistema impessoal que chega

\footnotetext{
269 "A pobreza, como vimos, não está "democraticamente" distribuída entre as raças. Os negros encontram-se sobre-representados na pobreza e na indigência, consideradas tanto a distribuição etária, como a regional e a estrutura de gênero. A intensidade na desigualdade de renda entre brancos e negros no interior de cada raça também é significativa. [...] Os negros freqüentam a riqueza do país, mas são participantes minoritários. Os brancos são mais ricos e mais desiguais. Os negros, mais iguais e mais pobres. A escolaridade de brancos e negros, por sua vez, nos expõe, com nitidez, a inércia do padrão de discriminação racial. Apesar da melhoria nos níveis médios de escolaridade de brancos e negros ao longo do século, o padrão de discriminação, isto é, a diferença de escolaridade dos brancos em relação aos negros, mantém-se estável entre as gerações". Ricardo HENRIQUES, Desigualdade Racial no Brasil: Evolução das Condições de Vida na Década de 90. Disponível [on line] em http://www.ipea.gov.br/pub/td/td_2001/td0807.pdf Além disso, "a proporção de negros em situação de pobreza continua duas vezes superior à de brancos". Radar Social 2006, p. 26. Disponível [on line] em http://www.ipea.gov.br

${ }^{270}$ Jessé SOUZA, A Construção Social da Subcidadania, pp. 121-122.

${ }^{271}$ Maria Sylvia de Carvalho FRANCO, Homens Livres na Ordem Escravocrata, p. 33.

272 Jessé SOUZA, A Construção Social da Subcidadania, p. 123-124.

${ }^{273}$ Jessé SOUZA, A Construção Social da Subcidadania, p. 129.
} 
como prática institucional quase pura, sem o arcabouço simbólico que na Europa foi responsável pela generalização - também para as classes subalternas - do tipo humano contingente e improvável que serve de base para a economia capitalista ${ }^{274}$.

A persistência desse modelo de exclusão constitui um grave entrave à efetivação da cidadania através dos mecanismos políticos e jurídicos do Estado Democrático de Direito, bem como um entrave à generalização dos padrões impessoais de interação necessários ao desenvolvimento das organizações, dos sistemas funcionais e do direito como mecanismo de mediação social.

As relações que se estabelecem entre o senhor, proprietário, e o dependente destituído de tudo, que tem sua própria subsistência subsumida ao talante daquele de cuja vontade ele depende, só fazem recrudescer a incapacidade de compreensão relativamente a relações impessoais, o que, obviamente, é um grave entrave à imposição do direito como forma de mediação $\operatorname{social}^{275}$.

A derrocada do patriarcalismo pessoal e familiar como forma primária de ordenação da sociedade brasileira e a sua gradual substituição por instituições impessoais recém-importadas se iniciam com a chegada da família real portuguesa ao Rio de Janeiro em $1808^{276}$. Segundo Jessé Souza, esse evento marcou o início de uma "revolução silenciosa" em todas as esferas da vida da colônia. Os padrões de comportamento entre os sexos se alteraram. O patriarca perdeu poder sobre a sua mulher e sobre os seus filhos, e o seu conhecimento tradicional se desvalorizou, cedendo espaço para o conhecimento formal produzido pelas organizações educacionais e que atendia às novas exigências funcionais de uma sociedade em transformação ${ }^{277}$. Essa revolução estrutural e simbólica implantou no país, de cima para baixo, novos valores burgueses e individualistas, que alteraram a posição e o prestígio relativo dos grupos e introduziram novos elementos de distinção entre eles ${ }^{278}$.

\footnotetext{
274 Jessé SOUZA, A Construção Social da Subcidadania,

${ }^{275}$ Orlando VILLAS BÔAS FILHO, Teoria dos Sistemas e o Direito Brasileiro, p. 319.

${ }^{276}$ Jessé SOUZA, A Construção Social da Subcidadania, pp. 137-138.

277 Jessé SOUZA, A Construção Social da Subcidadania, p. 139-140.

${ }^{278}$ Jessé SOUZA, A Construção Social da Subcidadania, p. 141.
} 
O processo brasileiro de modernização, no entanto, não foi marcado somente pelo influxo exógeno de ideologias e padrões institucionais advindos da Europa e que se mesclaram às estruturas escravistas e patrimonialistas da colônia, dando origem a uma realidade sui generis. Ele também foi marcado por um projeto modernizador próprio, surgido no Estado autoritário varguista que se consolidou a partir de 1930. O projeto varguista enfatizava no plano econômico a industrialização, capitaneada pela indústria de base, e no plano político a inclusão dos trabalhadores urbanos, ainda que sobre bases corporativas, repressivas e desmobilizadoras ${ }^{279}$.

Esse projeto perdurou até a estagflação da década de 1980, alternando fases de democracia formal plena com fases de autoritarismo político, e foi responsável por transformar uma das regiões mais atrasadas do planeta na então oitava maior economia do mundo. Apesar dos cinqüenta anos de crescimento econômico contínuo, o projeto varguista, principalmente após o golpe militar de 1964, também foi marcado pela concentração da renda, pelo aprofundamento das desigualdades regionais, pela proletarização do campo, pelo êxodo rural, pela urbanização descontrolada e pelo achatamento do salário mínimo.

O processo brasileiro de modernização não só não produziu uma inclusão efetiva da população nos sistemas funcionais como foi responsável pelo aprofundamento da desigualdade social e pela eclosão de novas formas de marginalização. Embora alguns indicadores sociais tenham melhorado após a redemocratização e o advento da Constituição Federal de 1988, o Brasil ainda possui $11,4 \%$ da sua população em situação de indigência e 30,1\% em situação de pobreza ${ }^{280}$. Ainda existem 14 milhões de pessoas em situação de insegurança alimentar grave e outros 25,5 milhões em situação de insegurança alimentar moderada ${ }^{281}$. O desemprego atinge $10 \%$ da população ${ }^{282}$, sendo que $24 \%$ dos empregos do país são informais ${ }^{283}$, além dos subempregos que, apesar de formalizados, não fornecem renda suficiente para atender às necessidades básicas de alimentação, vestuário, transporte, educação e lazer da família, visto que a

\footnotetext{
${ }^{279}$ Jessé SOUZA, A Construção Social da Subcidadania, p. 153.

${ }^{280}$ Considera-se a indigência (ou pobreza extrema) a condição da população que sobrevive com menos de $1 / 4$ de salário mínimo domiciliar mensal per capita e pobreza a situação daqueles que vivem com rendimentos entre 1/4 e 1/2 de salário mínimo. Radar Social 2006, p. 25.

${ }^{281}$ http://www.ibge.gov.br/home/presidencia/noticias/noticia_visualiza.php?id_noticia=600

282 Radar Social 2005, p. 32. Disponível [on line] em http://www.ipea.gov.br

${ }^{283}$ Radar Social 2005, p. 34.
} 
renda média do trabalhador brasileiro é de apenas $\mathrm{R} \$ 639,30^{284}$. O país ostenta a segunda pior distribuição de renda do mundo ${ }^{285}$.

${ }^{284}$ Radar Social 2005, p. 37.

${ }^{285}$ Radar Social 2005, p. 60. 


\section{VIOLÊNCIA, REDES SOCIAIS E EXCLUSÃO.}

La más alta formalización del decidir puede coexistir con la más alta informalidad de la constitución de autoridad.

Rafaelle De Giorgi.

\subsection{A Violência nas Interações Sociais: o “Código do Sertão”.}

Conforme analisado no capítulo anterior, os altos índices de exclusão social na realidade brasileira podem ser explicados a partir de dois aspectos constitutivos: a) a escravidão, conjugada à existência de uma parcela de indivíduos livres, porém pobres, que se movimentavam nas margens do processo produtivo, gerou um enorme contingente de párias urbanos e rurais, que jamais foram incluídos nos sistemas funcionais; b) sem o apoio de uma esfera moral autônoma, como a existente na modernidade central, o processo brasileiro de modernização se deu a partir de fortes traços personalistas, da dominação pessoal e do recurso à violência como forma de mediação das interações ${ }^{286}$.

${ }^{286}$ Orlando VILLAS BÔAS FILHO, Teoria dos Sistemas e o Direito Brasileiro, p. 327. 
Maria Sylvia de Carvalho Franco, em seu famoso ensaio, descreveu o papel da violência como forma de mediação a partir da análise das relações comunitárias travadas no Brasil predominantemente rural do século XIX. De rigor metodológico ímpar, muitas vezes ausente em outros ensaios brasileiros clássicos, a abordagem sociológica de Franco se recusa a explicar a violência a partir de traços psicológicos dos indivíduos, preferindo recorrer, ao invés disso, a variáveis explicativas como a cultura, as normas sociais e os processos de socialização que moldam e regulam as interações.

Segundo Franco, essa forma de violência chamada "código do sertão" surge de maneira semi-automática nas relações entre vizinhos, colegas de trabalho e familiares, a partir de motivos fúteis e problemas corriqueiros, que poderiam ser resolvidos com recurso ao diálogo. Nesse mundo da vida pouco racionalizado comunicativamente (de acordo com a terminologia de Habermas ${ }^{287}$ ), eram freqüentes os crimes deflagrados contra vizinhos, colegas de trabalho e familiares, sendo que antes do conflito agressores e vítimas conviviam de maneira amistosa ${ }^{288}$.

Homens matam-se em desavenças "cujas causas que houveram foi somente uma pequena dúvida que ambos tiveram por ter o assassino de propósito posto seus animais em plantações do assassinado". Essas "malquerenças havidas por causas de animais e plantações" foram o ponto de partida de inúmeros delitos, ocorridos em circunstâncias que constituíam motivos frívolos, de acordo com a jurisprudência da época ${ }^{289}$.

As providências ofensivas e defensivas para a salvaguarda dos interesses materiais ou simbólicos da população eram prerrogativas e obrigações pessoais, e não prerrogativas e obrigações do direito positivado por um Estado cuja falta não era substancialmente sentida. É nesse contexto que surge a figura do capanga ou jagunço, categoria instrumento dos grandes proprietários de terra e composta por um "conjunto

287 Segundo Habermas, num mundo da vida racionalizado comunicativamente, o acervo de conhecimentos (cultura), as normas sociais que regulam as interações (sociedade) e os padrões de socialização (personalidade) possibilitam uma predominância da resolução dialógica dos conflitos. Esse agir orientado para o entendimento não pressupõe, necessariamente, o consenso (que é um resultado que pode ser obtido ou não), mas pressupõe uma disposição para o diálogo. Jürgen HABERMAS, Theorie des Kommunikativen Handelns.

${ }^{288}$ Maria Sylvia de Carvalho FRANCO, Homens Livres na Ordem Escravocrata, p. 23.

${ }^{289}$ Maria Sylvia de Carvalho FRANCO, Homens Livres na Ordem Escravocrata, p. 24. 
de homens cujas vidas não tinham muito valor, nem encontravam muita razão de ser naquela sociedade 290 ,

Esses homens formalmente livres, destituídos de meios próprios de subsistência e dotados de uma vida despojada de significado para aqueles de quem dependiam, tudo deviam e nada de especial podiam oferecer para os senhores das fazendas nas quais se instalavam. Por isso mesmo, transformavam-se em seus instrumentos para qualquer fim, inclusive os de ofensa e de morte. Acolhidos pela rede de proteção do fazendeiro, esses empregados adquiriam para si parte do prestígio que este possuía, pelo menos no tocante à impunidade para os seus atos de ilegalidade ${ }^{291}$.

Nesse ambiente onde a bravura e a ousadia se institucionalizam como norma social, o controle da violência por parte do Estado é dificultado em função da “aprovação expressa das práticas violentas e a apreciação positiva de seus autores ${ }^{292 ", ~}$ As convenções e normas sociais passam a colidir frontalmente com as normas jurídicas, prejudicando a sua eficácia, e a discrepância de modos de vida faz com que os atos de violência adquiram sentidos nitidamente opostos para o direito e para os seus perpetradores e observadores próximos: os comportamentos juridicamente reprovados são considerados pelos habitantes do campo "retos e legítimos ou mesmo compulsórios e nobilitantes ${ }^{293}$,.

Embora ainda esteja presente em várias regiões do país, o "código do sertão" cedeu lugar parcialmente a uma forma de violência característica dos centros urbanos. Trata-se da violência engendrada pela semântica do acesso aos bens de consumo produzidos pelo sistema econômico contrastada com a não-realização desse acesso para a parcela da população excluída ou subincluída nos sistemas funcionais, fenômeno endêmico nos países da nova periferia ${ }^{294}$. Mais do que uma criminalidade destinada a

\footnotetext{
${ }^{290}$ Maria Sylvia de Carvalho FRANCO, Homens Livres na Ordem Escravocrata, p. 143.

${ }^{291}$ Maria Sylvia de Carvalho FRANCO, Homens Livres na Ordem Escravocrata, p. 146.

${ }^{292}$ Maria Sylvia de Carvalho FRANCO, Homens Livres na Ordem Escravocrata, pp. 54-55.

${ }^{293}$ Maria Sylvia de Carvalho FRANCO, Homens Livres na Ordem Escravocrata, p. 55.

${ }^{294}$ A partir de pressupostos distintos (e problematicamente psicologistas), o diagnóstico de Bauman, para quem esse tipo de criminalidade é um produto inevitável da "sociedade de consumidores": “[...] quanto mais elevada a 'procura do consumidor' (isto é, quanto mais elevada a sedução do mercado), mais a sociedade dos consumidores é segura e próspera. Todavia, simultaneamente, mais amplo e mais profundo é o hiato entre os que desejam e os que podem satisfazer os seus desejos, ou entre os que foram seduzidos e passam a agir do modo como essa condição os leva a agir e os que foram seduzidos mas se mostram impossibilitados de agir do modo como se espera agirem os seduzidos". Zygmunt BAUMAN, $O$ MalEstar na Pós-Modernidade. Tradução de Mauro Gama e Cláudia Martinelli Gama. Rio de Janeiro: Jorge Zahar, 1998, p. 55.
} 
matar a fome daquele que a pratica, trata-se de uma criminalidade voltada a satisfazer o desejo por bens de consumo muitas vezes supérfluos. Para esses indivíduos, a alternativa à criminalidade não é a liberdade ou a modernidade entendidas como valores positivos (e nem uma igualdade de oportunidades de inclusão que só existe enquanto “ideologia”), mas um grau de exclusão ainda mais aprofundado ${ }^{295}$.

\subsection{As Redes Sociais e as Expectativas Sociais.}

A exclusão e a subinclusão dos sistemas funcionais, o personalismo, a dominação pessoal e o "código do sertão" contribuem para produzir aquilo que Orlando Villas Bôas Filho denominou "incapacidade de compreensão relativamente a relações impessoais, o que, obviamente, é um grave entrave à imposição do direito como forma de mediação social ${ }^{296 ", ~ e ~ M a r i a ~ S y l v i a ~ d e ~ C a r v a l h o ~ F r a n c o ~ d e n o m i n o u ~ a u s e ̂ n c i a ~ d e ~}$ “condições favoráveis para a cristalização de uniformidades de conduta prescritas e respeitadas de modo estrito ${ }^{297}$,

Com base na análise de Tércio Sampaio Ferraz Jr., é possível afirmar que a sociedade brasileira é marcada pela rivalidade e pela prestância, em oposição aos países centrais, onde prevalecem formas de interação baseadas na cooperação e na competição ${ }^{298}$. Na sociedade brasileira, prevalece aquilo que Sérgio Buarque de Holanda denominou "espírito de facção", caracterizado pelo estigma de traidor que recai sobre aquele que abandona o seu grupo, seja esse grupo a família patriarcal do período colonial e imperial ou os modernos grupos personalistas que se formam nas mais diversas esferas da vida política ou cotidiana ${ }^{299}$.

${ }^{295}$ Giancarlo CORSI, "Redes de la Exclusión". in Fernando Castañeda SABIDO e Angélica Cuéllar VÁZQUEZ (Coord.), Redes de Inclusión: la construcción social de la autoridad, p. 41.

${ }^{296}$ Teoria dos Sistemas e o Direito Brasileiro, p. 319.

${ }^{297}$ Homens Livres na Ordem Escravocrata, p. 31.

${ }^{298}$ Tércio Sampaio FERRAZ JR., "Justiça Material como um Código Fraco na Comunicação Normativa", in Estudos de Filosofia do Direito: reflexões sobre o poder, a liberdade, a justiça e o direito, pp. 231244.

${ }^{299}$ Sérgio Buarque de HOLANDA, Raízes do Brasil. São Paulo: Companhia das Letras, 1995, pp. 77 e ss. 
Em localidades personalistas, os padrões de interação valorizam os vínculos afetivos, como aqueles que unem familiares e amigos próximos, e as regras formais encontram dificuldade para se generalizar congruentemente em função da valorização de virtudes como a misericórdia, a magnanimidade e a caridade ${ }^{300}$. Esses valores flexibilizam a aplicação das regras de cunho impessoal (tanto as normas jurídicas quanto as regras morais baseadas em critérios de justiça formal), que passa a ocorrer de maneira altamente seletiva. Na política brasileira, esse padrão personalista de interação pode ser observado na famosa máxima de Arthur Bernardes, incorporada por Getúlio Vargas: "aos meus amigos, tudo; aos meus inimigos, a lei".

Enquanto nas localidades cooperativas e competitivas a distribuição de posições sociais se baseia predominantemente em valores e regras formais, nas localidades marcadas pela rivalidade e pela prestância ela se baseia principalmente no prestígio pessoal, que é variável e instável ${ }^{301}$. A alternância de posições sociais não se dá a partir da obediência a regras e princípios como o mérito e a formação educacional, mas a partir da obediência quase cega aos superiores hierárquicos. A lealdade a quem possui prestígio é critério de "ascensão social". A obediência voluntária a regras é reservada aos idiotas, e a sujeição a elas não é sinônimo da existência de direitos que se fazem cumprir, mas um sinal de fraqueza social ${ }^{302}$.

Diante da prevalência do personalismo afetivo nas interações sociais, a construção de padrões impessoais de interação social baseados em papéis sociais e normas jurídicas resta prejudicada. Na modernidade central, a esfera moral autônoma de cunho religioso logrou generalizar um padrão impessoal de interação adequado para a implantação da empresa capitalista, da lógica funcional e da rule of law. É importante deixar claro que essa relação entre imperativos funcionais e padrões de interação social não se dá a partir da precedência causal dos primeiros sobre os segundos (ou viceversa), mas a partir da mútua afinidade e complementaridade, conforme já analisado por Weber $^{303}$.

\footnotetext{
${ }^{300}$ Tércio Sampaio FERRAZ JR., "Justiça Material como um Código Fraco na Comunicação Normativa”, pp. 240 e ss.

${ }^{301}$ Tércio Sampaio FERRAZ JR., "Justiça Material como um Código Fraco na Comunicação Normativa", p. 241.

302 Guillermo O'DONNEL, "Poliarchies and the (Un)Rule of Law in Latin American". Paper presented at the Meeting of the Latin American Studies Association. Chicago, September 1998, p. 14.

${ }^{303}$ Max WEBER, A Ética Protestante e o Espírito do Capitalismo.
} 
Nesse ponto, faz-se necessário ressaltar que não cabe à abordagem sociológica alçar o padrão impessoal europeu de interação ao status de ideal normativo a ser perseguido pelos países periféricos. A análise feita até aqui, a partir de tipos ideais weberianos, possui objetivos meramente explicativos. Uma avaliação extremamente crítica desse processo de "normalização" e "disciplinamento" destinado a moldar um tipo de sujeito adequado à lógica funcional pode ser encontrada na obra de Foucault e na obra da primeira geração da Escola de Frankfurt ${ }^{304}$. A sociologia econômica estadunidense, inspirada em Polanyi, também se insurgiu contra o projeto de afastar os componentes afetivos, amorosos e sexuais das organizações, de modo a criar um "local de trabalho asséptico", o que para Schultz representa um "velho sonho gerencial de criar um ambiente de trabalho perfeitamente racional, destituído de sexualidade e de outras paixões que provocam distrações ${ }^{305, "}$.

Antes de analisar as conseqüências do padrão personalista de interação social para o direito e para a política, é preciso analisá-lo com mais cuidado. Segundo Luhmann, a sociedade se reproduz por meio de interações orientadas por expectativas de comportamento ${ }^{306}$. As expectativas sociais de comportamento são respostas para o problema da incerteza (dupla contingência) inerente a qualquer interação social, e constituem as estruturas sociais por excelência. Elas são expectativas generalizadas na dimensão temporal, social, material e espacial, ou seja, são estruturas que perduram no tempo (embora possam se modificar ao longo da história), orientam um grande número de interações, dizem respeito a situações específicas e são encontradas em localidades específicas.

As expectativas de comportamento possibilitam a reprodução da sociedade e impedem que ela se dissolva no caos e na incerteza. Graças à existência de expectativas de comportamento, sabemos que é recomendável adotar comportamentos distintos no local de trabalho e numa festa entre amigos. Também são as expectativas de comportamento que fornecem uma linguagem comum e um acervo de tópicos que podem ser utilizados ou que devem ser evitados (trata-se aqui de algo muito próximo do

\footnotetext{
${ }^{304}$ Michel FOUCAULT, Vigiar e Punir. Max HORKHEIMER e Theodor ADORNO, Dialética do Esclarecimento. Tradução de Guido Antonio de Almeida. Rio de Janeiro: Jorge Zahar, 1985. Habermas, da mesma forma, a partir de uma análise sub-repticiamente normativa, divide esse processo em duas vertentes: a racionalização instrumental do "sistema" e a racionalização comunicativa do mundo da vida, cabendo à segunda sobrepor-se à primeira. Jürgen HABERMAS, Theorie des Kommunicativen Haldelns. ${ }^{305}$ Vicki SCHULTZ, “The Sanitized Workplace". Yale Law Journal, 112, 2003, p. 2191 (tradução livre).

${ }^{306}$ Niklas LUHMANN, Social Systems, p. 285.
} 
mundo da vida de Habermas). Elas constituem não apenas constrangimentos (constraints, Beschränkungen), mas também recursos que viabilizam as interações sociais e até mesmo antecipam a ocorrência de determinados resultados: muito provavelmente, o próximo convidado que chegar à supracitada festa apertará a mão dos homens e dará um beijo no rosto das mulheres, pois as convenções sociais da "cultura brasileira" recomendam que isso seja feito.

Qualquer comportamento que contraria uma expectativa é interpretado automaticamente como perturbação, mesmo que posteriormente ele seja avaliado de maneira positiva (pensemos no caso de alguém que oferece um presente inesperado ou repentinamente se despe em público). ${ }^{307}$ Os comportamentos que contrariam expectativas socialmente generalizadas são comportamentos inesperados, que provocam surpresas e introduzem novidades. $O$ inesperado expõe a contingência das estruturas sociais e demonstra que as coisas podem ocorrer de outro modo, anulando a redução de complexidade levada a cabo pela estrutura. ${ }^{308}$

Uma expectativa socialmente generalizada aglomera uma série de acontecimentos desconexos e heterogêneos sob o rótulo "contrariar uma expectativa". 309 O desapontamento da expectativa pode levar a duas situações distintas. No primeiro caso, a expectativa é abandonada e ocorre uma adaptação (aprendizado). No segundo caso, a expectativa é mantida e o desapontado continua exigindo um comportamento de acordo com a expectativa. No primeiro caso, estamos diante de uma expectativa cognitiva. No segundo caso, estamos diante de uma expectativa normativa. As expectativas normativas são expectativas que se mantêm apesar da ocorrência eventual de comportamentos que as contrariam: mesmo que alguém tenha se comportado de maneira contrária ao esperado, não deveria ter feito isso, e a expectativa continua válida.

Essa visão da teoria dos sistemas de Niklas Luhmann não compreende a sociedade como um conjunto harmonioso no qual cada elemento insere-se harmoniosamente no sistema, de modo a mantê-lo em funcionamento. Mesmo que essa crítica (ideológica e muitas vezes despida de implicações teóricas relevantes)

\footnotetext{
307 " $[. .$.$] the formation of expectations reveals deviance to be disturbance without requiring one to know$ why”. Niklas LUHMANN, Social Systems, p. 292.

${ }^{308}$ Niklas LUHMANN, Sociologia do Direito, volume I, p. 66.

${ }^{309}$ Niklas LUHMANN, Social Systems, p. 293.
} 
eventualmente se aplique ao estrutural-funcionalismo de Radcliffe-Brown, Malinowski e Parsons, ela não se aplica ao funcional-estruturalismo de Luhmann ${ }^{310}$. Para Luhmann, a sociedade é profundamente profícua em conflito e contradição ${ }^{311}$. As expectativas sociais não indicam necessariamente a presença de consenso e costumam sofrer alterações com o passar do tempo, além do fato de existirem na sociedade expectativas contraditórias ou que não fornecem uma orientação clara para a ação.

A sociologia atual está plenamente capacitada para considerar como normais as contradições entre expectativas e até mesmo um grau tolerável de conflito declarado, reconhecendo isso até mesmo como uma condição para a manutenção do sistema social em um ambiente demasiadamente complexo ${ }^{312}$.

A emergência de sistemas funcionais autopoiéticos fez com que as expectativas sociais se especializassem, produzindo conjuntos de expectativas (imperativos funcionais) válidos somente para sistemas funcionais específicos e que entram em conflito com os imperativos de outros sistemas funcionais. Segundo Loet Leydersdorff, o potencial empírico da teoria dos sistemas reside principalmente no estudo de quais são as expectativas existentes na sociedade, quem as possui e em que momento e local elas existem $^{313}$ (caso aceitemos a sugestão de Jorge Galindo Monteagudo de adicionar uma dimensão espacial à teoria dos sistemas $^{314}$ ).

As expectativas sociais podem se referir a pessoas, papéis sociais, programas (regras e fins) e valores $^{315}$. As pessoas são construções comunicativas que permitem que as comunicações sejam endereçadas (de ego para alter) ou imputadas (de alter para ego) a indivíduos concretos (que existem somente enquanto corpos e consciências). As expectativas pessoais se referem a experiências e ações de indivíduos concretos (espera-

\footnotetext{
${ }^{310}$ Sobre as críticas ideológicas ao antigo funcionalismo, as considerações de Percy S. COHEN, Teoria Social Moderna. Tradução de Christiano Monteiro Oiticica. Rio de Janeiro: Zahar, 1970, pp. 50-84.

311 Ver o capítulo denominado justamente "Conflito e Contradição", em Niklas LUHMANN, Social Systems, pp. 357-404.

312 Niklas LUHMANN, Sociologia do Direito, volume I, p. 77.

${ }^{313}$ Loet LEYDERSDORFF, "Luhmann Reconsidered: Steps Towards an Empirical Research Programme in the Sociology of Communication?". Forthcoming in Colin GRANT (Ed.), Beyond Universal Pragmatics: Essays in the Philosophy of Communication. Oxford: Peter Lang.

${ }^{314}$ Jorge Galindo MONTEAGUDO, "La Teoría Sistémica de Niklas Luhmann: alcances e limites", p. XL. 315 Niklas LUHMANN, Sociologia do Direito, volume I, pp. 99 e ss. ___, Social Systems, pp. 315 e ss.
} 
se que João faça $x$, mas não $y$ ). Para que existam expectativas convergentes em relação a determinado indivíduo, é preciso conhecê-lo pessoalmente, o que pressupõe uma história de interações em comum, uma vida em comum onde essa pessoa se expôs e se tornou conhecida.

Os papéis sociais são conjuntos de expectativas sobre uma atividade específica. As expectativas relativas a papéis sociais permitem um grau maior de abstração do que as expectativas relativas a pessoas, pois um papel social pode ser exercido por qualquer pessoa que apresentar determinada qualificação ou aptidão ${ }^{316}$. Os papéis sociais permitem uma maior redução de complexidade, pois tornam desnecessário levar em consideração a pessoa como um todo, possibilitando a estabilização de expectativas mais específicas (hoje em dia, um político só tem o seu cargo ameaçado por não ter sido um bom marido nos Estados Unidos da América, por exemplo). Em caso de frustração de uma expectativa relativa a um papel, apenas algumas informações serão relevantes, e outras informações poderão ser descartadas porque dizem respeito a outros papéis ou somente à pessoa. Isso dificulta que as pessoas sejam alvo de aprovação ou reprovação social como um todo, de acordo com o código moral amigo/inimigo.

Um grau de abstração ainda mais alto pode ser alcançado com a formação de regras decisórias. Podem existir várias regras válidas para uma mesma pessoa ou papel social, e uma mesma regra pode ser válida para várias pessoas ou papéis. Além disso, as regras podem ser alteradas sem que as pessoas ou papéis percam a sua identidade, e a vigência de uma regra não se encerra com a morte de pessoas ou pelo fato de um papel estar vago, sem ninguém para exercê-lo. Quando as condições de aplicação das regras estão especificadas, elas são denominadas programas. Os programas podem ser finalísticos - quando prescrevem um fim que a ação deve atingir - ou condicionais quando imputam uma consequiência a uma determinada ação (uma sanção ou uma recompensa, de acordo com um esquema se X/ então $Y){ }^{317}$

Os valores, por fim, constituem o nível mais abstrato de expectativas. Eles são julgamentos sobre a preferibilidade de ações, embora não especifiquem quais ações

\footnotetext{
316 " [...] a role is tailored to what an individual human being can perform. [...] On the one hand, only a portion of a human being's behavior is expected in the form of a role; on the other, the role is a unity that can be performed by many different human beings: the role of a patient, a teacher, an opera singer, a mother, a first-aid worker, and so forth". Niklas LUHMANN, Social Systems, p. 316.

${ }^{317}$ Niklas LUHMANN, Sociologia do Direito, volume I, p. 103. Existe um erro na edição brasileira, que traduz Zweckprogramme como "programas intencionais", quando o correto seria "programas finalísticos”. Versão original: Rechtssoziologie. Opladen: Westdeutscher Verlag, 1987, p. 88.
} 
possuem preferência sobre quais outras ações. Por isso, eles fornecem orientações muito indeterminadas para a formação de expectativas. Ao contrário das regras, que expressam com maior exatidão o que deve ser feito, os valores oferecem um campo de ação muito amplo e, além disso, pouco dizem sobre o que fazer em caso de conflitos entre valores. Devemos ser sinceros e também devemos ser bons. Mas o que dizer dos casos nos quais a sinceridade provoca sofrimento em alguém? É recomendável mentir nesses casos?

Em decorrência do seu alto grau de abstração, torna-se impossível generalizar congruentemente uma "hierarquia de valores" ou um "sistema de valores" (no segundo capítulo, afirmamos que os princípios jurídicos, que são valores positivados, não possuem prevalência prima facie uns sobre os outros). Um valor, por si só, não pode servir como justificativa para uma ação, já que isso depende da consideração dos outros valores em jogo e das outras linhas de ação possíveis. Por isso, os valores exigem a construção de programas, que informam com maior exatidão o que é esperado e quais são as opções existentes ${ }^{318}$.

Esses quatro planos de expectativas (pessoas, papéis, programas e valores) não se relacionam de maneira evolutiva, no sentido de que primeiro temos o surgimento das expectativas relativas a pessoas, depois o surgimento das expectativas relativas a papéis sociais, e assim por diante, embora eles estejam listados em ordem crescente de abstração. Conforme a sociedade vai se tornando mais complexa, o que ocorre é uma maior diferenciação entre os quatro planos de expectativas, e todos passam a ser exigidos com maior intensidade ${ }^{319}$. Além disso, a diferenciação permite que eles se modifiquem de maneira relativamente independente.

No atual estágio de desenvolvimento da modernidade central, o centro de gravidade da formação de estruturas sociais se localiza nos planos intermediários dos papéis e programas ${ }^{320}$. Somente nesses planos a complexidade da sociedade pode ser reproduzida adequadamente, já que as pessoas são identificações excessivamente

\footnotetext{
${ }^{318}$ Para Luhmann, a função que os valores desempenham na sociedade é distinta. "Value consensus then alleviates communication about the program's contingency: about program development, adaptation to a situation, change in programs, or even their becoming obsolescent. In view of such problems, one can at least, in communication, use points of departure that are undisputed (or are very difficult to dispute because they are backed by morality) and build on the expectation that everyone must agree on at least these values. Values serve in the communication process as a kind of probe with which one can test whether more concrete expectations are also at work". Social Systems, p. 318.

${ }^{319}$ Niklas LUHMANN, Sociologia do Direito, volume I, p. 104.

${ }^{320}$ Niklas LUHMANN, Sociologia do Direito, volume I, p. 107.
} 
concretas, e os valores, excessivamente abstratos ${ }^{321}$. Tendo em vista o massivo número de papéis sociais existentes na sociedade, as pessoas são tornadas intercambiáveis em função de qualificações ou aptidões específicas. Os valores, por sua vez, são ideologizados e tornados inoperacionalizáveis. Na sociedade atual, o problema não é ter valores, mas saber o que eles abarcam e como agir em caso de conflitos valorativos.

As considerações acima esboçadas permitem analisar de maneira mais rigorosa o padrão personalista de interação existente em países da nova periferia como o Brasil. Nessas localidades, é possível observar uma concentração das expectativas sociais no plano das pessoas e no plano dos valores. A comunicação periférica se alimenta de uma forte referência às pessoas, inseridas em redes sociais que se distinguem pelo prestígio social e pela visibilidade que possuem ${ }^{322}$. As redes sociais são estruturas que permitem endereçar comunicações a pessoas específicas e mobilizá-las para a consecução de objetivos específicos ${ }^{323}$. Quem está inserido na rede sabe com quais pessoas é possível contar, para que fins e em que momento mobilizar esses contatos (ou os contatos dos "contatos", e assim por diante).

A peculiaridade da realidade brasileira não está na simples presença de redes sociais (que existem por toda a sociedade), mas na maneira como elas atuam e nos resultados que produzem. Esse padrão personalista de interação não é um resíduo prémoderno, pois foi formado a partir do momento em que o processo de diferenciação funcional se deparou com as condições históricas do período colonial e imperial (a escravidão, o personalismo pré-moderno, a dominação pessoal e o código do sertão), dando origem a uma realidade histórica que é marcadamente moderna ${ }^{324}$.

Enquanto a sociedade estratificada tinha como ponto de referência a superioridade moral das famílias nobres, na sociedade funcionalmente diferenciada as redes sociais periféricas têm como ponto de referência as posições ocupadas no interior das organizações, como a administração pública, as empresas, os tribunais, as

\footnotetext{
321 "Individuals and values then join forces to symbolize the foundation of societal life, while roles and programs underline the requirements of complexity". Niklas LUHMANN, Social Systems, p. 319.

322 Giancarlo CORSI e Raffaele DE GIORGI, Ridescrivere la Questione Meridionale. Lecce: Pensa Multimedia, 1998, p. 29.

${ }^{323}$ Michael BOMMES e Veronica TACKE, “Luhmann's Systems Theory and Network Theory”, in David SEIDL \& Kai BECKER (Eds.), Niklas Luhmann and Organizational Studies, pp. 285 e ss. Nesse artigo também é possível encontrar uma vasta bibliografia sobre a teoria das redes sociais (network theory).

${ }^{324}$ Orlando VILLAS BÔAS FILHO, Teoria dos Sistemas e o Direito Brasileiro, pp. 364 e ss.
} 
universidades, os hospitais, as associações, etc. ${ }^{325}$ A ocupação do cargo permite que pessoas singulares adquiram um prestígio social que as distingue das demais e que constitui um recurso comunicativo decisivo no contexto local ${ }^{326}$.

A formação de expectativas sociais não se concentra no plano dos papéis e dos programas, mas no plano das pessoas e valores. Para saber o que esperar de um papel social (político, governante, policial, juiz, professor, médico, empresário, líder religioso, líder comunitário) e para saber como uma regra será aplicada (seja a regra jurídica, organizacional ou moral), é preciso conhecer quem exerce o papel ou quem é responsável pela adjudicação da regra. Conhecer o ocupante da posição, saber o que ele fez no passado, quais são os seus amigos e inimigos e quem é necessário mobilizar para acessá-lo pode fazer a diferença na obtenção de resultados favoráveis ${ }^{327}$.

A forte referência às pessoas convive com uma forte orientação da comunicação por valores difusos como a prestância e a rivalidade. Aquele que tem a possibilidade de prestar um favor não pode se recusar a fazê-lo, sob pena de ver-se em pouco tempo excluído da rede de favores e prestações recíprocas ${ }^{328}$. Os rivais, por sua vez, devem ser tratados com excessivo rigor ou notória má-vontade. Importa que a ação não se oriente de maneira universalista e impessoal, pois a própria tentativa de imposição da impessoalidade é compreendida como um estar comprometido com outras pessoas ou com outros interesses; como uma distância, no mínimo, suspeita.

A rede social de favores recíprocos gera o seu próprio mecanismo de exclusão. Quem não conhece ninguém possui dificuldades maiores para se inserir nos sistemas funcionais, mesmo possuindo as qualificações e aptidões formalmente necessárias ${ }^{329}$. No caso da compra e venda de vantagens, cristaliza-se o "pacto do silêncio": quem conhece os fatos nada pode dizer sobre eles, sob pena excluir-se dos benefícios do mercado de vantagens e ainda comprometer-se a si próprio. Além disso, quem pensa em denunciar possui a expectativa de que a sua morte é um resultado mais provável do que a condenação judicial dos denunciados.

\footnotetext{
${ }^{325}$ Giancarlo CORSI e Raffaele DE GIORGI, Ridescrivere la Questione Meridionale, p. 29.

${ }^{326}$ Giancarlo CORSI e Raffaele DE GIORGI, Ridescrivere la Questione Meridionale, p. 30.

${ }^{327}$ Giancarlo CORSI, "Redes de la Exclusión", p. 37.

${ }^{328}$ Niklas LUHMANN, Inclusión y Exclusión, p. 182.

${ }^{329}$ Niklas LUHMANN, Inclusión y Exclusión, p. 182.
} 
O padrão personalista de interação favorece a emergência de critérios materiais de justiça (e ao mesmo tempo se alimenta deles). Os papéis sociais e regras das instituições político-jurídicas européias, baseados no código forte da justiça formal, quando transpostos para a realidade brasileira, sofrem uma releitura a partir do código fraco da justiça material, que permite um desempenho mais flexível dos papéis e uma aplicação mais flexível das regras, a partir de formas imprecisas e vagas de equidade ${ }^{330}$. A presença de diferentes códigos morais pode fazer com que uma mesma informação seja compreendida de maneira distinta na modernidade central e em países periféricos como o Brasil.

As redes sociais periféricas são estruturas que parasitam os recursos dos sistemas funcionais. A inclusão na rede angaria preferência em licitações, aprovação em provas e concursos, tratamento policial diferenciado, obtenção de favores políticos e a possibilidade de trilhar uma carreira política sob a proteção de pessoas influentes e com acesso diferenciado a recursos econômicos (muitas vezes ilegais). ${ }^{331}$ Embora não sejam as únicas responsáveis pela desigualdade social na modernidade periférica, as redes de favores e interesses servem como mecanismos que reproduzem a diferença entre a inclusão e a exclusão dos sistemas funcionais a partir da reprodução da diferença entre inclusão e exclusão no interior da própria rede ${ }^{332}$.

\subsection{As Redes Sociais e o Estado Democrático de Direito.}

Como afirmado anteriormente, a peculiaridade da realidade brasileira não está na presença de redes sociais, mas na forma como elas atuam e nos resultados que produzem. A teoria das redes sociais (network theory) estadunidense já vem estudando há algum tempo a maneira como as redes de interação produzem resultados sociais de

\footnotetext{
${ }^{330}$ Tércio Sampaio FERRAZ JR., "Justiça Material como um Código Fraco na Comunicação Normativa", p. 243. Orlando VILLAS BÔAS FILHO, Teoria dos Sistemas e o Direito Brasileiro, pp. 360 e ss.

${ }^{331}$ Niklas LUHMANN, Inclusión y Exclusión, p. 185.

332 Niklas LUHMANN, Inclusión y Exclusión, pp. 185 e ss. Giancarlo CORSI, "Redes de la Exclusión”, pp. 29-43. Raffaelle DE GIORGI, "Redes de la Inclusión". In Fernando Castañeda SABIDO e Angélica Cuéllar VÁZQUEZ (Coord.), Redes de Inclusión: la construcción social de la autoridad, pp. 17-28.
} 
larga escala ${ }^{333}$. A teoria dos sistemas luhmanniana, da mesma forma, embora tenha se concentrado primordialmente no plano dos sistemas funcionais, reconhece que a sociedade se reproduz através de interações orientadas por expectativas de comportamento $^{334}$ e que os sistemas funcionais operam a partir das condições estruturais que lhes são dadas no plano local ${ }^{335}$.

Embora a teoria das redes e a teoria dos sistemas divirjam quanto à natureza dos processos macrossociológicos ${ }^{336}$, ambas reconhecem a importância das redes sociais na produção da confiança, um poderoso mecanismo de redução de complexidade ${ }^{337}$. A confiança é um mecanismo voltado para a seleção de informação: as pessoas dão preferência às informações oriundas de emissores confiáveis. Ela normalmente se produz ao longo de interações constantes e, quando confiamos em alguém, esperamos uma menor probabilidade de que as nossas expectativas sejam frustradas e uma maior probabilidade de êxito na interação. A confiança fornece uma sólida base a partir da qual é possível agir, e possui um importante papel na redução de custos de informação (e, sob a perspectiva econômica, também na redução de custos de transação ${ }^{338}$ ).

Pelo fato de gerarem previsibilidade comportamental, as redes sociais capazes de construir confiança podem ser consideradas equivalentes funcionais ao direito (ou, mais especificamente, "equivalentes prestacionais"). Ceteris paribus, quanto maior a confiança existente na rede, menor é a probabilidade de ocorrência de comportamentos que frustram as expectativas dos participantes e, portanto, menor a necessidade de

\footnotetext{
${ }^{333}$ Mark GRANOVETTER, "The Impact of Social Structure on Economic Outcomes", p. 34.

${ }^{334}$ Niklas LUHMANN, Social Systems, p. 285.

335 "The high dependence of all autopoietic systems on history also has to be considered. Autopoietic systems always lever their operations on condition that already exist as a structure". Niklas LUHMANN, Law as a Social System, p. 490.

${ }^{336}$ Uma tentativa magistral de conciliar a teoria das redes sociais com a teoria dos sistemas pode ser encontrada no artigo de Michael Bommes e Veronica Tacke, "Luhmann's Systems Theory and Network Theory". Trata-se de um frutífero campo de estudos, de suma importância para a operacionalização da teoria dos sistemas para a pesquisa microssociológica.

337 Niklas LUHMANN, Vertrauen: ein Mechanismus der Reduktion sozialer Komplexität. Stuttgart: Lucius \& Lucius, 2000.

338 "One common example is that a culture of corruption may impose high economic costs and require many off-the-books transactions to carry on normal production of goods and services. [...] Less often noted, but probably more important, are savings achieved when actors pursue economic goals through non-economic institutions and practices to whose costs they made little or no contribution. For example, employers who recruit through social networks need not—and probably could not—pay to create the trust and obligations that motivate friends and relatives to help one another find employment. Such trust and obligations arise from the way a society's institutions pattern kin and friendship ties, and any economic efficiency gains resulting from them are a byproduct, typically unintended, of actions and patterns enacted by individuals with noneconomic motivations". Mark GRANOVETTER, "The Impact of Social Structure on Economic Outcomes", p. 35.
} 
recorrer a mecanismos judiciais para garantir a previsibilidade comportamental e solucionar conflitos. Essas redes sociais geram aquilo que Avner Greif chama de "self enforcing institutions", conjuntos de expectativas comportamentais que sustentam a si próprias, a partir da obediência espontânea dos participantes ou a partir da imposição de sanções informais (ou sanções de segunda ordem, na terminologia de Robert E. Scott). ${ }^{339}$

É o que acontece na economia chinesa contemporânea, que recorre a práticas de relacionamento pessoal (denominadas guanxi) como mecanismos de controle comportamental e solução de controvérsias, conforme o exemplo de Orlando Villas Bôas Filho ${ }^{340}$. Enquanto as regras jurídicas são universais, impessoais e formais, os guanxi são particularistas, pessoais e informais. Antes que possamos alçar essas práticas sociais - e práticas sociais análogas - à condição de "equivalentes funcionais ao direito formal e racional, na medida em que reduziriam os custos de transações comerciais e facilitariam o crescimento econômico ${ }^{341}$,", no entanto, é necessário tecer algumas considerações.

Em primeiro lugar, se alguém afirmou que "sistema jurídico formal e racional seria precondição indispensável ao desenvolvimento da economia de mercado ${ }^{342,}$, com certeza não foi o próprio Max Weber. Para Weber, a economia capitalista e o direito racional-formal são fenômenos correlatos e afins, porém independentes ${ }^{343}$.

O capitalismo moderno prospera igualmente e apresenta os mesmos traços econômicos, característicos não apenas sob ordens jurídicas que, do ponto de vista do direito, possuem normas e institutos jurídicos extremamente diferentes, [...] mas que também divergem entre si, o máximo possível, em seus princípios estruturais formais últimos ${ }^{344}$.

Não é preciso fazer referência à China contemporânea para saber que não há relação necessária entre o direito racional-formal e a economia capitalista. Weber já

\footnotetext{
${ }^{339}$ Avner GREIF, "Self Enforcing Institutions: comparative and historical institutional analysis". Stanford University - Prepare for presentation in European School on New Institutional Economics (ESNIE), 2004.

${ }^{340}$ Orlando VILLAS BÔAS FILHO, Teoria dos Sistemas e o Direito Brasileiro, pp. 373-374.

${ }^{341}$ Orlando VILLAS BÔAS FILHO, Teoria dos Sistemas e o Direito Brasileiro, p. 374.

${ }^{342}$ Orlando VILLAS BÔAS FILHO, Teoria dos Sistemas e o Direito Brasileiro, p. 373.

${ }^{343}$ Maria José Fariñas DULCE, La Sociologia del Derecho de Max Weber, p. 368.

${ }^{344}$ Max WEBER, Economia e Sociedade, Volume II, p. 149.
} 
estava ciente disso ao analisar o que os seus comentadores chamam de "problema inglês": o capitalismo se desenvolveu em primeiro lugar na Inglaterra, que adotava um modelo de direito racional-material, avesso à codificação e baseado em precedentes judiciais $^{345}$. Além disso, existem atualmente no ocidente inúmeros mercados que se apóiam fortemente em práticas pessoais que promovem uma segurança complementar à segurança proporcionada pelas normas jurídicas, tornando a fiscalização e a punição estatais muitas vezes desnecessárias ${ }^{346}$.

A relação entre as redes sociais e o direito racional-formal não é, necessariamente, uma relação de exclusão. As redes sociais podem atuar como mecanismos complementares ao direito, cristalizando expectativas que reforçam as expectativas normativas juridicamente asseguradas e diminuindo a necessidade de fiscalização e sanções estatais. Para que isso aconteça, o direito deve ser capaz de generalizar congruentemente expectativas na dimensão temporal (sanção), social (procedimento judicial) e material (programas condicionais de decisão) e impedir a generalização de expectativas contrárias às normas jurídicas. Além disso, o direito deve ser considerado legítimo pelos cidadãos de uma maneira que eles se sintam incumbidos da tarefa de fiscalizar o cumprimento das leis e de impor sanções informais àqueles que as desobedecem. ${ }^{347}$

Nesse caso, o sistema jurídico observa as práticas que têm lugar no interior das redes sociais como lícitas. O sistema político pode apoiá-las e fomentá-las, já que uma menor litigiosidade poupa investimentos na ampliação da capacidade decisória dos

\footnotetext{
${ }^{345}$ Maria José Fariñas DULCE, La Sociologia del Derecho de Max Weber, pp. 369 e ss.

346 Sobre o mercado bancário, a afirmação de Michel Ferrary: "to obtain information needed for the financial risk evaluation and to reduce the information asymmetry between bankers and borrowers, financial counselors integrate social networks to establish bonds of trust and to accumulate social capital. The quality of the social bond determines the quality of the gathered information and therefore the quality of the risk evaluation". "Trust and Social Capital in the Regulation of Lending Activities". Journal of Socio-Economics, 31 (2003), pp. 673-699. Sobre outros mercados de consumidores, o estudo de Paul DI MAGGIO e Hugh LOCH, "Socially Embedded Consumer Transactions: for what kind of purchases do people most often use networks?". American Sociological Review, 1998, vol. 63, pp. 619-637.

347 "The law influences the behavior of its citizens in various ways. Well understood are the direct effects of legal rules. By imposing sanctions or granting subsidies, the law either expands or contracts the horizon of opportunities within which individuals can satisfy their preferences. [...] In recent years, the social norms literature has shown that law can also have indirect effects on incentives. Thus, for example, a legal ban on smoking in public places or a "pooper-scooper" law can motivate citizens not to smoke in certain areas or to clean up after their dogs even where the state has no resources invested in direct (or first order) enforcement. By empowering neighbors and other citizens to use public ridicule as an enforcement technique,these laws can influence behavior by imposing informal (or second order) sanctions, such as shaming". (grifos nossos). Robert E. SCOTT, "The Limits of Behavorial Theories of Law and Social Norms", p. 1603.
} 
tribunais. As relações pessoais de confiança que operam nas margens da licitude, portanto, não são equivalentes funcionais ao direito em sentido estrito, mas justamente o contrário: são indicadores de que o sistema jurídico generaliza congruentemente expectativas normativas (ou seja, cumpre a sua função), controla comportamentos e minimiza a eclosão de conflitos (nesses últimos dois casos, através de efeitos jurídicos indiretos). Ao minimizar a eclosão de conflitos, o sistema jurídico oferece uma valiosa prestação ao sistema político, descarregando-o da necessidade de mobilizar o seu potencial coercitivo para garantir, em casos específicos, o comportamento conforme o direito.

Não é isso que acontece no caso das redes periféricas de favorecimento e corrupção. Essas redes servem como instâncias mediadoras entre as pessoas e os sistemas funcionais e reproduzem um padrão personalista de interação que dificulta a generalização congruente de expectativas normativas. Além disso, elas funcionam muitas vezes como meio para a obtenção de vantagens ilícitas. Redes de corrupção que drenam recursos públicos, que contrabandeiam, descaminham, traficam, seqüestram, roubam, receptam, ameaçam, extorquem, praticam atos concorrenciais ilegais (cartéis, dumping, etc.) e inúmeros outros atos criminosos são freqüentes na realidade brasileira. Trata-se de redes sociais, e não de meras interações esporádicas, porque se cristalizam e se reproduzem parasitariamente, sem que o Estado Democrático de Direito seja capaz de desmantelá-las.

As redes sociais de favorecimento se cristalizam no interior das mais diversas organizações formais, inibindo a sua racionalidade e, conseqüentemente, inibindo a racionalidade dos sistemas funcionais nos quais elas se inserem ${ }^{348}$. As organizações econômicas passam a comprar mercadorias roubadas e buscar favorecimentos das mais diversas espécies junto à administração pública. As organizações religiosas se convertem em mecanismos para o enriquecimento de líderes religiosos, muitas vezes

\footnotetext{
348 Atualmente, as principais organizações da sociedade estão inseridas em um sistema funcional específico (como as empresas e organizações estatais, inseridas respectivamente no sistema econômico e no sistema político). Também existem organizações que desempenham tarefas concernentes a mais de um sistema funcional, como as universidades, que desempenham atividades educacionais e científicas. Outras, como a maçonaria, são multifuncionais e não se inserem em nenhum sistema funcional específico. Niklas LUHMANN, La Sociedad de la Sociedad, pp. 655-672.. Os sistemas funcionais fornecem complexidade reduzida (premissas estruturais e ordem) que as organizações podem utilizar no desempenho de tarefas específicas, o que possibilita e ao mesmo tempo limita o desenvolvimento organizacional. Thomas DREPPER, "On the Desideratum of a Society Theory of Organizations in the Work of Niklas Luhmann", in: David SEIDL \& Kai BECKER (Eds.), Niklas Luhmann and Organizational Studies, pp. 174 e ss.
} 
mediante a prática de crimes como a evasão fiscal e a lavagem de dinheiro. As organizações educacionais aprovam, reprovam e concedem títulos e certificados com base em critérios econômicos e políticos, e não com base em critérios educacionais e pedagógicos.

A atividade parasitária das redes periféricas reforça no ambiente a expectativa de que a incerteza do direito pode ser compensada pela certeza proporcionada pela inclusão na rede ${ }^{349}$. As comunicações que ocorrem no interior das redes introduzem novas distinções que se sobrepõem às distinções operadas pelo código jurídico lícito/ilícito. Num ambiente marcado pela prestância e pela rivalidade, onde os critérios de justiça são aplicados de maneira flexível, as operações do sistema jurídico passam a sofrer interferências particularistas, provindas do seu ambiente, que prejudicam a sua autonomia operacional.

Segundo Luhmann, o sistema jurídico na modernidade central é um sistema operacionalmente fechado e cognitivamente aberto: ele se abre cognitivamente para o ambiente ao observar fatos (os comportamentos juridicamente relevantes e as conseqüências das decisões jurídicas) e se fecha operacionalmente ao interpretá-los de acordo com os seus programas (regras, princípios, precedentes, dogmática jurídica, etc.), ou seja, de acordo com o sentido que ele mesmo constrói ${ }^{350}$. Na realidade brasileira, no entanto, em algumas das suas operações o sistema jurídico não se orienta pelos seus programas, mas por critérios fornecidos por outros códigos existentes na sociedade, como o código moral (amigo/inimigo), o código político (governo/oposição) e o código econômico (ter/não-ter). ${ }^{351}$

O código jurídico lícito/ilícito deixa de operar autorreferencialmente, segundo o seu paradoxo constitutivo (é lícito tudo aquilo que corresponde ao direito, ou seja, é lícito aquilo que é lícito), e passa a operar com referência a outros códigos sociais: lícito porque amigo (e ilícito porque inimigo), lícito porque governo (e ilícito porque oposição) ou lícito porque possui dinheiro (e ilícito porque não possui dinheiro). ${ }^{352} \mathrm{~A}$ corrupção sistêmica e os altos níveis de exclusão bloqueiam parcialmente a autopoiesis

\footnotetext{
${ }^{349}$ Rafaelle DE GIORGI, "Redes de la Inclusión”, p. 27.

${ }^{350}$ Niklas LUHMANN, Law as a Social System, pp. 93 e ss.

${ }^{351}$ Marcelo NEVES, "E se Faltar o Décimo Segundo Camelo? Do Direito Expropriador ao Direito Invadido", pp. 147 e ss.

${ }^{352}$ Marcelo NEVES, "E se Faltar o Décimo Segundo Camelo? Do Direito Expropriador ao Direito Invadido", pp. 147 e ss.
} 
do sistema jurídico, que passa a vivenciar momentos de allopoiesis. ${ }^{353}$ Incapaz de filtrar as influências oriundas de outras esferas da sociedade, as operações do sistema jurídico passam a ser determinadas diretamente pelo dinheiro, pelo poder e pelas relações de amizade e inimizade.

Trata-se, ademais, de um direito ineficaz e que enfrenta graves empecilhos ao desempenho da sua função. Segundo Luhmann, o direito não busca uma integração social no sentido habermasiano do termo, controlando o desenvolvimento dos sistemas funcionais de maneira linear e hierárquica ${ }^{354}$. A sociedade hipercomplexa e funcionalmente diferenciada não pode ser juridicamente (ou politicamente) controlada. Os sistemas funcionais operam a partir das condições existentes na realidade, tanto as condições sociais quanto as condições extra-sociais (como a existência de seres humanos e a existência de um meio-ambiente que possibilite a sua sobrevivência), e somente dessa maneira é possível falar em integração ${ }^{355}$. Isso implica, dentre outras coisas, que cada sistema funcional limita o desenvolvimento dos demais.

O direito administra condições que limitam o desenvolvimento da política, da economia, da religião, e assim por diante. Ele busca impedir a generalização de expectativas incompatíveis com as normas jurídicas, bem como a generalização de comportamentos ilícitos (pois isso colocaria em risco a existência das expectativas normativas juridicamente asseguradas). O sistema jurídico exerce pressões para que os demais sistemas funcionais adotem seleções compatíveis com as normas jurídicas (mas não pode controlar a maneira como isso é feito e nem garantir que isso ocorra). Quem possui uma expectativa considerada ilícita deve abandoná-la, ou seja, deve se readaptar e deixar a expectativa ilícita esvaecer, ou então enfrentar o alto custo de mantê-la.

$\mathrm{Na}$ realidade brasileira, entretanto, o direito é incapaz de produzir esses dois resultados num nível socialmente adequado. Na dimensão temporal, as sanções

\footnotetext{
353 Ao contrário da autopoiesis, que indica que um sistema produz os seus próprios elementos, a allopoiesis, termo derivado das palavras gregas allós (outro) e poiesis (criação, produção), indica a reprodução de um sistema através dos critérios, códigos e programas do seu ambiente. Marcelo NEVES, "From the Autopoiesis to the Allopoiesis of Law". Journal of Law and Society. Volume 28, Number 2, June 2001, p. 255.

${ }^{354}$ Ver as críticas de Luhmann a Habermas em Niklas LUHMANN, "Quod Omnes Tangit: remark on Jürgen Habermas's Legal Theory. In Michel ROSENFELD e Andrew ARATO (Ed.), Habermas on Law and Democracy: critical exchanges. Berkeley: University of California Press, 1998, pp. 157-172.

355 “[...] por integración entenderemos únicamente la reducción de los grados de libertad de los sistemasparciales - reducción que se sigue de los límites externos del sistema sociedad y del entorno interno que con ellos separa dicho sistema”. Niklas LUHMANN, La Sociedad de la Sociedad, p. 478.
} 
legalmente previstas freqüentemente deixam de ser aplicadas e, mesmo quando são aplicadas, não conduzem ao aprendizado (readaptação de expectativas) dos criminosos. Como conseqüência, o direito torna-se incapaz de impor a obrigatoriedade das normas jurídicas perante os comportamentos que as desobedecem ${ }^{356}$. Na dimensão social, a corrupção sistêmica e os favorecimentos personalistas interrompem a incerteza quanto ao resultado do procedimento judicial, que se torna um "jogo de cartas marcadas". Além disso, os tribunais são expostos a inúmeras mazelas organizacionais, como o número excessivo de processos e a lentidão para julgá-los.

Na dimensão material, os programas "inexistentes, omissos ou parciais ${ }^{357 "}$ " são incapazes de garantir uma prática decisória universalista. Ao contrário do que ocorre nos países centrais, não se trata de um engessamento dos programas decisórios, insensíveis às demandas da sociedade, mas de uma deficiência reflexiva responsável por argumentos jurisprudenciais e doutrinários que não se apóiam e não se inspiram mutuamente e que são incapazes de obter aceitação geral ${ }^{358}$. Desenvolve-se então uma dogmática incapaz de controlar a consistência das decisões jurídicas (tratar igualmente os casos iguais e desigualmente os casos desiguais) e que não encontra ressonância nas decisões dos tribunais - a não ser enquanto argumento de autoridade subordinado às constelações concretas de interesses ${ }^{359}$.

Um direito ineficaz, incapaz de generalizar congruentemente expectativas comportamentais, contribui para a ocorrência de conflitos potencialmente destrutivos entre os sistemas funcionais. Esses conflitos - que constituem um grave óbice à realização da diferenciação funcional ${ }^{360}$ - diferem substancialmente dos problemas de integração existentes na modernidade central. Os problemas de integração nos países centrais decorrem principalmente da insuficiente abertura cognitiva (heterorreferência), que torna os sistemas funcionais indiferentes às demandas dos demais sistemas

\footnotetext{
${ }^{356}$ Ver as considerações de Luhmann sobre as sanções em Sociologia do Direito, volume I, p. 116.

357 Celso Fernandes CAMPILONGO, "A Posição dos Tribunais no Centro e na Periferia do Sistema Mundial", p. 68.

358 Marcelo NEVES, "E se Faltar o Décimo Segundo Camelo? Do Direito Expropriador ao Direito Invadido", pp. 163-167. O problema não estaria, portanto, na falta de variedade e no excesso de redundância das decisões jurídicas (a culpa não é do positivismo jurídico!), mas na sua falta de redundância e excesso de variedade (a sensação de "anything goes").

359 Marcelo NEVES, "E se Faltar o Décimo Segundo Camelo? Do Direito Expropriador ao Direito Invadido", pp. 163-167.

${ }^{360}$ Marcelo NEVES, “Die Staaten im Zentrum und die Staaten an der Peripherie”, pp. 257-258.
} 
funcionais e do restante da sociedade ${ }^{361}$. Esse "excesso" de diferenciação funcional se manifesta principalmente na expansão da política e do direito (burocratização) e da economia (mercantilização) em direção aos demais sistemas funcionais e às esferas informais da sociedade, como a família ${ }^{362}$.

Nos países periféricos, por outro lado, os problemas de integração são ocasionados principalmente pelo insuficiente fechamento operativo dos sistemas funcionais, incapazes de operar somente de acordo com os seus critérios e, portanto, incapazes de consolidar um alto grau de complexidade. O fechamento operacional insuficiente se manifesta através de problemas de auto-observação (os sistemas funcionais possuem dificuldades para conectar as suas operações e, dessa maneira, se delimitar frente ao ambiente) e de autodescrição (os sistemas funcionais possuem dificuldades para refletir acerca da sua totalidade e, dessa maneira, construir estruturas que aumentam a sua seletividade e permitem níveis mais altos de complexidade). ${ }^{363}$

Embora a diferenciação funcional esteja presente nessas localidades, ela é instável e constantemente ameaçada pela sobreposição de códigos e pela hipertrofia dos meios de comunicação simbolicamente generalizados dinheiro e poder. É importante salientar que o fenômeno da allopoiesis na modernidade periférica atinge não apenas o sistema jurídico, mas também o sistema político. A política sofre limitações à sua autopoiesis quando não se orienta pela distinção lícito/ilícito (que é o seu código secundário), sendo sistematicamente bloqueada por pressões advindas do ambiente, distanciando-se do modelo previsto pela Constituição ${ }^{364}$. Dessa forma, a mais alta formalização do processo decisório pode coexistir com a mais alta informalidade da constituição de autoridade ${ }^{365}$.

\footnotetext{
${ }^{361}$ Marcelo NEVES, "Die Staaten im Zentrum und die Staaten an der Peripherie", pp. 255 e ss. Claus OFFE, "The Utopia of the Zero-Option: modernity and modernization as normative political criteria", pp. 6 e ss. Enrique PERUZZOTTI, "Modernization and Juridification in Latin America: A Reassessment of the Latin American Developmental Path", pp. 63 e ss.

${ }^{362}$ Ver as considerações de Habermas sobre a "colonização" do mundo da vida pelo Estado e pelo mercado. Theorie des Kommunikativen Handelns. Band 2: Zur Kritik der Funktionalistischen Vernunft.

${ }^{363}$ Para a diferença entre observação e descrição, Niklas LUHMANN, Law as a Social System, pp. 422 e ss.

${ }_{364}^{365}$ Marcelo NEVES, Entre Têmis e Leviatã: uma relação difícil, p. 245.

365 Raffaele DE GIORGI, "Introducción". In Fernando Castañeda SABIDO e Angélica Cuéllar VÁZQUEZ (Coord.), Redes de Inclusión: la construcción social de la autoridad, p. 12.
} 


\subsection{Corrupção, Exclusão e o Estado Democrático de Direito.}

Enquanto nos países da modernidade central a corrupção é localizada, no Brasil ela tende à generalização e se manifesta como corrupção sistêmica ${ }^{366}$. Alguns sociólogos brasileiros, entretanto, minimizam o papel da corrupção como variável explicativa dos déficits de desempenho e legitimação do sistema político e do sistema jurídico. Para Jessé Sousa, por exemplo, existe um "foco distorcido e exagerado de "cruzadas contra a corrupção", como se este não fosse um problema de qualquer sociedade moderna, seja central ou periférica". ${ }^{367}$ Orlando Villas Bôas Filho, da mesma forma, afirma que "corrupção há em toda parte e atribuí-la apenas às sociedades classificadas como periféricas, tal como a brasileira, parece ser justamente uma conseqüência da objetivação naturalista do senso comum pela teoria". 368

Uma ilustração do "senso comum" através de dados, no entanto, sugere que os esquemas de corrupção custam dez bilhões de reais ao ano para o país, o que corresponde a $0,5 \%$ do Produto Interno Bruto ${ }^{369}$. Embora tenha obtido melhoras no combate à corrupção nos últimos anos, o país ainda aparece classificado como altamente corrupto no ranking anual da Transparency International. Numa escala de um (mais corrupção) a dez (menos corrupção), o país obteve a pontuação 2.7 no ranking de 1997 e 3.7 no ranking de $2009^{370}$. E mesmo que o sistema brasileiro de votação seja um dos mais eficientes e seguros do mundo, cerca de 8,3 milhões de eleitores foram instados a vender o voto nas eleições de 2006 , o que corresponde a $8 \%$ do eleitorado ${ }^{371}$.

Altos níveis de corrupção estão associados a menores níveis de investimento e crescimento econômico $^{372}$. A corrupção reduz a efetividade das políticas públicas e encoraja os atores econômicos e do terceiro setor a operarem na ilegalidade, violando as

\footnotetext{
${ }^{366}$ Marcelo NEVES, "Die Staaten im Zentrum und die Staaten an der Peripherie”, p. 259.

${ }^{367}$ Jessé SOUZA, A Construção Social da Subcidadania, p. 183.

${ }^{368}$ Orlando VILLAS BÔAS FILHO, Teoria dos Sistemas e o Direito Brasileiro, p. 394.

${ }^{369}$ Marcos Fernandes G. da SILVA, Ética e Economia. Rio de Janeiro: Campus-Elsevier, 2006.

370 Transparency International. Corruption Perceptions Index 2009. Disponível em http://www.transparency.org/policy_research/surveys_indices/cpi/2009/cpi_2009_table

371 Cláudio Weber ABRAMO, "Compra de Votos nas Eleições de 2006, Corrupção e Desempenho Administrativo". Relatório de pesquisa feita pelo IBOPE Opinião para a Transparência Brasil e a União Nacional dos Analistas e Técnicos de Finanças e Controle. Fevereiro 2007. Disponível em http://www.transparencia.org.br/docs/compravotos2006.pdf

372 Susan ROSE-ACKERMAN, Corruption and Government: causes, consequences and reform. Cambridge: Cambridge University Press, 1999, pp. 2-3.
} 
leis trabalhistas, tributárias, ambientais e comerciais. Além disso, altos níveis de corrupção desencorajam o investimento estrangeiro direto (pois introduzem custos e incertezas que afugentam os investidores).

Mesmo quando coexiste com o crescimento econômico, a corrupção gera distorções e custos. Os agentes públicos de alto escalão tendem a apoiar investimentos públicos vultosos e ineficientes e a gastar menos com a manutenção de investimentos passados. Construir "obras faraônicas" ou "elefantes brancos" é mais interessante do que investir na manutenção da infra-estrutura existente. A corrupção encoraja o gasto excessivo em infra-estrutura, mas reduz o montante total de investimento e limita o investimento estrangeiro direto ${ }^{373}$.

Num cenário de corrupção generalizada, os atores econômicos com poucos escrúpulos, como aqueles engajados em negócios ilegais, adquirem vantagens competitivas. Isso gera incentivos para que os demais atores se corrompam (o que aumenta o preço da corrupção), sob o risco de serem eliminados do mercado. Além disso, a tolerância à corrupção encoraja a sua disseminação para outras áreas do governo $^{374}$. No Brasil, essa tolerância à corrupção é praticada tanto pelas autoridades quanto pelo público, que freqüentemente reelege políticos envolvidos em escândalos de corrupção, embora a maioria se diga contrária à política do "rouba, mas faz". ${ }^{375}$

Outros estudos empíricos demonstram que países altamente corruptos tendem a subaproveitar o seu capital humano, pois investem menos em educação ${ }^{376}$. Isso ocorre porque a educação proporciona menos oportunidades para lucros ilegais do que outros tipos de gasto público que demandam níveis intensivos de capital. Os efeitos do baixo nível de investimento em educação - principalmente na educação elementar - sobre a reprodução da exclusão, da desigualdade e do subdesenvolvimento, por sua vez, são mais do que óbvios.

Além disso, os estudos da tradição da justiça procedimental e de José Álvaro Moisés com base nos dados coletados pelo Instituto Latinobarômetro demonstram que a

\footnotetext{
${ }^{373}$ Susan ROSE-ACKERMAN, Corruption and Government, p. 3.

${ }^{374}$ Susan ROSE-ACKERMAN, Corruption and Government, p. 16.

375 Cláudio Weber ABRAMO, "Compra de Votos nas Eleições de 2006, Corrupção e Desempenho Administrativo".

376 Paolo MAURO, "Corruption and the composition of Government Expenditure". Journal of Public Economics, 69, pp. 263-279. "Corruption and Growth". The Quarterly Journal of Economics, Vol. 110, No. 3, 1995, pp. 681-712.
} 
corrupção compromete a legitimidade das instituições políticas e jurídicas, pois dissemina entre o público a sensação de que resultados mais favoráveis poderiam ser obtidos de outra maneira. Segundo Moisés, os indivíduos convencidos de que a corrupção aumentou nos últimos anos têm razão de probabilidade igual a 1,3 vezes de apoiar o fechamento do Congresso Nacional, em comparação com os indivíduos que não possuem essa opinião ${ }^{377}$.

A experiência de práticas de corrupção envolvendo agentes públicos, partidos políticos e membros do Congresso Nacional (amplamente divulgadas pela mídia), sem que os meios de controle e repressão sejam considerados eficazes e efetivos, ajuda a explicar a alta incidência de cidadãos que apóiam modelos de democracia sem partidos e sem Congresso Nacional $^{378}$. Resta saber se o processo de deslegitimação das instituições básicas da democracia representativa poderá ser usado, no futuro, para alimentar alternativas antidemocráticas.

Não cabe perguntar, portanto, se mesmo sem as sobreposições particularistas à auto-reprodução do sistema jurídico e do sistema político no Brasil, estes estariam em condições de gerar a inclusão generalizada dos cidadãos excluídos, pois estas sobreposições particularistas possuem um peso considerável na reprodução da exclusão e da desigualdade ${ }^{379}$. Embora a corrupção não explique a formação da exclusão e da desigualdade na realidade brasileira, ela explica, em grande parte, a sua reprodução num cenário democrático e com alto nível de gasto público.

Os países mais corruptos simplesmente tendem a ser mais pobres, e podem ser capturados por um círculo vicioso onde a corrupção gera mais corrupção e desencoraja investimentos públicos e privados que gerariam renda e/ou aumentariam o bem-estar da população ${ }^{380}$. Além disso, quando os desenhos institucionais existentes favorecem ilicitamente os responsáveis pela sua criação e manutenção (os membros da administração pública, sobretudo parlamentares), eles se tornam path dependent, pois os incentivos para a sua alteração são baixíssimos.

\footnotetext{
377 José Álvaro MOISÉS, "Cultura Política, Instituições e Democracia: lições da experiência brasileira”. Revista Brasileira de Ciências Sociais, Vol. 23, nº 66, 2008, p. 33.

${ }^{378}$ José Álvaro MOISÉS, "Cultura Política, Instituições e Democracia, p. 36.

379 Esta é a pergunta feita por Orlando VILLAS BÔAS FILHO, Teoria dos Sistemas e o Direito Brasileiro, p. 255. Obviamente, existem outras explicações para a exclusão e a desigualdade, como a escravidão, o personalismo, a violência e fatores econômicos estruturais.

${ }^{380}$ Susan ROSE-ACKERMAN, Corruption and Government, p. 16.
} 
Não negamos que os altos índices de exclusão sobrecarregam o sistema político e o sistema jurídico, comprometendo a consecução da sua função ${ }^{381}$. A exclusão expõe a fragilidade do Estado Democrático de Direito na modernidade periférica perante a escassez de recursos, causando tensões sociais e prejuízos ao seu desempenho e à sua legitimação, tema que será tratado no próximo capítulo. Negamos, entretanto, que a sobrecarga do sistema político e do sistema jurídico em decorrência da exclusão e as sobreposições particularistas que colocam em risco a sua autonomia sejam explicações excludentes, quando o mais correto seria tratá-las como explicações complementares.

${ }^{381}$ Orlando Villas Bôas Filho faz essa afirmação acerca do sistema jurídico no Brasil. Teoria dos Sistemas e o Direito Brasileiro, p. 295. 


\section{APONTAMENTOS SOBRE A LEGITIMAÇÃO DO ESTADO DEMOCRÁTICO DE DIREITO NO BRASIL.}

Impedidos de ignorar a existência de problemas sociais, os governantes são compelidos a administrá-los.

Wanderley Guilherme dos Santos

\subsection{Direitos Sociais e Inclusão na Ordem Constitucional de 1988.}

A Constituição Federal de 1988 foi responsável pela positivação não só de direitos civis e políticos, mas também de vários direitos sociais, voltados a combater a exclusão e desigualdade herdadas da política militar de "fazer o bolo crescer para depois dividi-lo". Ao delinear claramente um Estado de Bem-Estar, baseado nos direitos sociais enquanto mecanismos de concretização da cidadania, a "Constituição cidadã" abriu caminho para o aumento da capacidade prestacional do Estado através do aumento 
da carga tributária, que passou de 26,4\% do PIB em 1988 para 37,37\% do PIB em $2008^{382}$.

Entre 1985 e 2005, os gastos sociais das três esferas do governo passaram de 13,3\% do PIB para 21,87\% do PIB, um aumento de $65 \%{ }^{383}$. Os gastos com assistência social (Benefícios de Prestação Continuada, Serviços de Ação Continuada, BolsaFamília e Programa de Erradicação do Trabalho Infantil) aumentaram mais de dez vezes entre 1995 e $2005^{384}$. Trata-se de um cenário nitidamente oposto ao cenário europeu, onde a ausência de níveis satisfatórios de crescimento econômico, sentida desde o final da década de 1970, somada ao envelhecimento da população, tem levado à impossibilidade de manutenção da generosa rede de proteção social construída no período pós-guerra ${ }^{385}$.

[...] a análise da legislação que afeta as políticas sociais no período posterior a 1988 permite observar dois movimentos importantes: busca de mecanismos para elevar a arrecadação e equacionar os problemas fiscais e, ao mesmo tempo, ampliação da proteção das populações em situação de fragilidade, como as famílias com renda per capita inferior a um quarto do salário mínino. O crescimento das fontes de financiamento da seguridade social se deu com recorrentes elevações nas alíquotas e criação de novas contribuições sociais $^{386}$.

A partir de 1996 também foram criados mecanismos jurídicos destinados a proteger os gastos sociais contra cortes orçamentários. Três emendas constitucionais estabeleceram a vinculação de um percentual mínimo das receitas da União, dos Estados e dos Municípios aos gastos com educação (EC 14/1996), saúde (EC 29/2000)

\footnotetext{
${ }^{382}$ Fonte: Instituto Brasileiro de Planejamento Tributário (IBPT).

383 Jorge Abrahão de CASTRO, José Aparecido RIBEIRO, André Gambier CAMPOS e Milko MATIJASCIC, "A CF/88 e as Políticas Sociais Brasileiras". In José Celso CARDOSO JR. (org.), A Constituição Brasileira de 1988 Revisitada: recuperação histórica e desafios atuais das políticas públicas nas áreas econômica e social, Volume 1. Brasília: Ipea, 2009, p. 97.

${ }^{384}$ Passando de 0,08\% do PIB para 0,83\% do PIB. Ipea: Boletim de Políticas Sociais n n $^{\text {13 }} 2007$.

385 Jürgen HABERMAS, A Constelação Pós-Nacional: ensaios políticos. São Paulo: Littera Mundi, 2001. No mesmo sentido: Cláudio Hamilton dos SANTOS e Denise Lobato GENTIL, "A CF/88 e as Finanças Públicas Brasileiras". In José Celso CARDOSO JR. (org.), A Constituição Brasileira de 1988 Revisitada, Volume I, p. 152.

${ }^{386}$ CASTRO, RIBEIRO, CAMPOS e MATIJASCIC, “A CF/88 e as Políticas Sociais Brasileiras”, p. 75.
} 
e erradicação da pobreza (EC 31/2000), e uma emenda constitucional autorizou a vinculação de receitas para a promoção social e a inclusão (EC 42/2003). ${ }^{387}$

A positivação dos direitos sociais, a vinculação de receitas e a expansão dos gastos sociais podem ser compreendidas como tentativas de adequar a estrutura da sociedade à promessa de inclusão de toda a população nos sistemas funcionais, característica do discurso da modernidade. Na modernidade, pela primeira vez na história, a exclusão social, agora capitaneada pela diferenciação funcional e manifestada sob a forma de exclusão dos sistemas funcionais, aparece como incompatível com aquilo que a sociedade espera de si mesma: a exclusão torna-se escandalosa aos olhos da opinião pública, um motivo de vergonha para as operações de auto-observação da sociedade $^{388}$.

A partir da generalização do discurso da cidadania e dos direitos humanos no século XX, o Estado Democrático (e agora também Social) de Direito se vincula a uma dupla tarefa de inclusão: incluir no sistema político e no sistema jurídico e, ao mesmo tempo, propiciar os meios para a inclusão nos demais sistemas funcionais, principalmente no sistema econômico, no sistema de saúde e no sistema educacional ${ }^{389}$. Além de garantir mecanismos efetivos de representação e participação e tribunais acessíveis, o Estado se vincula à tarefa de propiciar o acesso à renda, à educação e à saúde e a proteção contra as incertezas e vicissitudes da economia de mercado. O processo de legitimação do Estado Democrático e Social de Direito, dessa maneira, se vincula ao desempenho obtido na promoção da inclusão e na concretização da cidadania, sejam as conquistas nessa seara efetivas ou meramente simbólicas.

Segundo T.H. Marshall, a concretização da cidadania pressupõe a efetivação dos direitos civis (liberdades frente ao Estado e aos particulares), políticos (participação nas decisões estatais) e sociais (satisfação das necessidades materiais básicas do ser humano). ${ }^{390} \mathrm{~A}$ inclusão dos direitos sociais no conceito de cidadania se justifica pelo

\footnotetext{
${ }^{387}$ Ricardo Lobo TORRES, “O Mínimo Existencial, os Direitos Sociais e Os Desafios de Natureza Orçamentária”. In Ingo Wolfgang SARLET e Luciano Benetti TIMM (Orgs.), Direitos Fundamentais: orçamento e reserva do possível. Porto Alegre: Livraria do Advogado, 2008, p. 74 e ss.

${ }^{388}$ Giancarlo CORSI, "Redes de la Exclusión”, p. 32.

389 Jost HALFMANN, "Der moderne Nationalstaat als Lösung und Problem der Inklusion in das politische System”. In Karl-Uwe HELMANN e Rainer SCHMALZ-BRUNS (Hrsg), Theorie der Politik: Niklas Luhmanns politische Soziologie. Frankfurt am Main: Suhrkamp, 2002, p. 265.

390 T.H. MARSHALL, Class, Citizenship and Social Development. Westport: Greenwood Press, 1973. Atualmente, fala-se também na ampliação da cidadania em direção aos direitos difusos, coletivos e transindividuais e à idéia de reconhecimento.
} 
fato de que a existência de condições materiais mínimas é pressuposto para o exercício dos direitos civis e políticos e para a inclusão em qualquer sistema funcional, inclusive no sistema político e no sistema jurídico. Sem os direitos sociais, o exercício das liberdades civis e das liberdades políticas resta prejudicado ${ }^{391}$. Por uma questão de ordem lógica, só existe liberdade quando existem condições fáticas para exercê-la ${ }^{392}$.

Os direitos sociais são direitos ao recebimento de uma prestação positiva específica do Estado, como o seguro-desemprego, uma vaga numa escola pública, um medicamento, etc. O seu papel na promoção da inclusão é subsidiário, pois os indivíduos, quando dispõem de meios financeiros suficientes e quando há oferta suficiente no mercado, também podem obter essas prestações de particulares ${ }^{393}$. Trata-se também de um mecanismo indireto de inclusão: o Estado pode apenas garantir os pressupostos para a inclusão nos demais sistemas funcionais, mas não pode realizar operações de inclusão que são próprias de cada um deles. Na sociedade moderna, cada sistema funcional administra os seus critérios de inclusão, e o Estado não pode intervir diretamente em sua operação sem provocar resultados desdiferenciadores.

A análise da questão dos direitos fundamentais sociais em contextos periféricos como o brasileiro deve evitar atribuir a sua insuficiente concretização à "má-vontade" dos donos do poder, a uma elite governante que, embora pudesse fazer o contrário, simplesmente deixa de cumprir o texto constitucional. Embora na realidade brasileira existam redes de favorecimento e corrupção que inibem a racionalidade dos sistemas funcionais e que drenam os seus recursos, a insuficiente concretização dos direitos sociais e, conseqüentemente, da cidadania, deve buscar explicações históricas e estruturais que em muito transcendem a intencionalidade dos atores sociais.

Em relação aos fatores históricos, cumpre assinalar em primeiro lugar que o sistema jurídico e o sistema político na nova periferia se deparam com um alto nível de exclusão social, que produz uma grande demanda por atuação estatal e, ao mesmo tempo, uma menor capacidade estatal para atendê-la. Em segundo lugar, mesmo atuando de maneira fragmentada, imediatista e ad hoc, as redes sociais de favorecimento e corrupção aumentam o custo das políticas públicas e diminuem a sua

\footnotetext{
391 "Embora um lugar-comum, é ainda incontestável que, sem os direitos sociais como droits-créances, os droits-libertés não têm sentido". Marcelo NEVES, Entre Têmis e Leviatã: uma relação difícil, p. 181.

${ }^{392}$ Robert ALEXY, Teoria dos Direitos Fundamentais, pp. 503-504.

${ }^{393}$ Robert ALEXY, Teoria dos Direitos Fundamentais, p. 499.
} 
efetividade. No próximo capítulo analisaremos como a exclusão e as redes sociais prejudicam o cumprimento da função do sistema jurídico (a generalização congruente de expectativas normativas) e do sistema político (a manutenção da capacidade de produção de decisões coletivamente vinculantes).

Em relação aos fatores estruturais, cumpre assinalar que a promoção da inclusão por meio da atividade estatal é limitada pela própria diferenciação funcional. A sociedade hipercomplexa e funcionalmente diferenciada não pode ser política ou juridicamente controlada e cada vez mais imputa às tentativas de controle o rótulo de uma utopia política de caráter legitimador ${ }^{394}$. As aspirações inclusivas do Estado são limitadas pelas exigências de autonomia oriundas dos diversos sistemas funcionais ${ }^{395} \mathrm{e}$ pela institucionalização dessa autonomia nas Constituições das democracias liberais sob a forma de direitos fundamentais de liberdade.

\section{Segundo Robert Alexy,}

“[...] os freqüentemente suscitados limites da capacidade de realização do Estado não decorrem apenas dos bem distribuíveis existentes, mas sobretudo daquilo que o Estado, para fins distributivos, pode tomar dos proprietários desses bens sem violar seus direitos fundamentais. Com frequiência fala-se não somente em uma colisão entre direitos fundamentais sociais de uns e direitos de liberdade de outro, mas também uma colisão entre direitos fundamentais sociais e direitos de liberdade do mesmo titular de direitos". 396

A colisão entre direitos sociais e direitos de liberdade é especialmente clara no caso do direito ao trabalho $\left(\mathrm{CF}\right.$, art. $\left.6^{\circ}\right){ }^{397}$ Em uma economia de mercado, o Estado possui um controle limitado sobre o objeto desse direito. Se ele quisesse concretizá-lo

\footnotetext{
${ }^{394}$ Stephan LANGE, "Die Politische Utopie der Gesellschaftsteuerung”. In Karl-Uwe HELMANN e Rainer SCHMALZ-BRUNS (Hrsg), Theorie der Politik: Niklas Luhmanns politische Soziologie, pp. 171193.

395 "Na sociedade mundial supercomplexa do presente, tornou-se uma exigência normativa que os códigos e programas de uma esfera de comunicação não se imponham, diretamente, a outra esfera de comunicação". Marcelo NEVES, "E se Faltar o Décimo Segundo Camelo? Do direito expropriador ao direito invadido", p. 167. Constatar a existência dessas exigências não significa emitir qualquer juízo de valor a respeito delas.

${ }^{396}$ Robert ALEXY, Teoria dos Direitos Fundamentais, p. 510.

${ }^{397}$ Robert ALEXY, Teoria dos Direitos Fundamentais, p. 509.
} 
garantindo um posto de trabalho para cada cidadão desempregado, teria (i) que empregar todos os desempregados na administração pública ou (ii) restringir a capacidade das organizações econômicas de dispor sobre postos de trabalho. A primeira solução, ao menos como solução geral, conduziria o Estado a uma crise orçamentária e produziria simplesmente um desemprego disfarçado de serviço público. A segunda solução conduziria a uma severa restrição da competência decisória das organizações econômicas ou mesmo ao fim da economia de mercado (desdiferenciação do sistema econômico). Além disso, ela esbarraria nos direitos fundamentais de liberdade dos proprietários dos meios de produção.

\subsection{O Estado Democrático de Direito e a Escassez.}

Outro fator estrutural que propicia e ao mesmo tempo limita a atuação estatal é a escassez. Como afirmamos anteriormente, numa sociedade onde os sistemas funcionais limitam a liberdade de desenvolvimento uns dos outros, a escassez é a mais forte condição limitadora, a condição de possibilidade das condições de possibilidade, a fórmula de contingência das fórmulas de contingência ${ }^{398}$. A escassez é um estado próprio do sistema econômico e não pode ser controlado pela política ou pelo direito. $\mathrm{O}$ sistema econômico, assim como os demais sistemas funcionais, é um sistema funcional autopoiético, e as suas operações são determinadas pela sua própria estrutura ${ }^{399}$.

Enquanto uma máquina não-trivial, no sentido de Heinz Von Foerster ${ }^{400}$, a economia só pode ser provocada pela política e pelo direito externamente, e a forma como ela reage a essas provocações não é regida por um esquema de causalidade-efeito (Durchgriffskausalität), como o acender de uma lâmpada ao clique de um interruptor

\footnotetext{
${ }^{398}$ Essa afirmação se mantém dentro da idéia luhmanniana de que não existe trade-off entre fórmulas de contingência, como legitimidade/escassez ou justiça/escassez. No caso analisado, trata-se de uma relação subsidiária entre a escassez e a legitimidade. Niklas LUHMANN, Die Politik der Gesellschaft, pp. 125126.

${ }^{399}$ Niklas LUHMANN, Die Wirtschaft der Gesellschaft.

${ }^{400}$ Sobre a distinção entre máquinas triviais e máquinas não triviais, Heinz VON FOERSTER, Observing Systems. Seaside: Intersystems Publications, 1981, p. 201.
} 
(um circuito elétrico é um exemplo de máquina trivial). ${ }^{401}$ Ao invés disso, a sua reação segue um esquema de causalidade-gatilho (Auslösekausalität): uma decisão política ou jurídica desencadeia reações econômicas que não podem ser controladas politicamente ou juridicamente. As decisões políticas e jurídicas são interpretadas como estímulos ou irritações pelo sistema econômico, que as processa de acordo com os seus critérios internos de aprendizagem.

As máquinas triviais sempre transformam um mesmo input num mesmo output, de maneira previsível (a menos que estejam quebradas ou desreguladas). As máquinas não triviais, por outro lado, são máquinas históricas, que transformam a si mesmas a cada operação, de maneira contingente e imprevisível ${ }^{402}$. A economia altera a si mesma a cada provocação da política e do direito, criando novas condições que orientarão as operações econômicas futuras. Por isso, toda decisão governamental possui um caráter necessariamente experimental, mesmo quando justificada retoricamente por critérios científicos $^{403}$.

Isso faz com que o Estado Democrático de Direito trabalhe sob uma dupla limitação estrutural: são limitados os seus recursos e os seus mecanismos para captá-los junto aos particulares. A tributação e o endividamento público possuem alcance e flexibilidade limitados e, quando utilizados de maneira equivocada, podem provocar resultados economicamente desastrosos, como o estrangulamento da atividade produtiva e a retração do consumo ${ }^{404}$. O mesmo é válido para a emissão de moeda: se o Estado pudesse controlar a escassez, bastaria emitir moeda sempre que os seus cofres estivessem vazios ou sempre que fosse preciso fomentar o mercado interno ${ }^{405}$.

Enquanto comprador ou vendedor, o Estado não possui status diferenciado na economia: sempre que adquirir um bem ou serviço, deve pagar por ele o mesmo preço que o vendedor está disposto a praticar numa transação com um particular ${ }^{406}$. Para o sistema econômico, o Estado como comprador ou vendedor é um agente econômico como todos os demais e, como todo agente econômico, está submetido à escassez de

\footnotetext{
${ }^{401}$ Sobre a diferença entre causalidade-efeito e causalidade-gatilho, Niklas LUHMANN, Organisation und Entscheidung, p. 401 e ss.

${ }^{402}$ Niklas LUHMANN, Law as a Social System, p. 91.

${ }^{403}$ Wanderley Guilherme dos SANTOS, Cidadania e Justiça: a política social na ordem brasileira. Rio de Janeiro: Campus, 1979, pp. 125-126.

${ }^{404}$ Niklas LUHMANN, Die Politik der Gesellschaft, p. 388.

${ }^{405}$ Basta relembrar os resultados desastrosos do encilhamento na primeira república.

${ }^{406}$ Niklas LUHMANN, Die Politik der Gesellschaft, pp. 383-384.
} 
recursos. O politicamente possível, portanto, depende do economicamente possível. E como a concretização dos direitos fundamentais requer grande alocação de recursos, que são captados junto à sociedade na forma de tributos e, algumas vezes, de endividamento público $^{407}$, cada vez mais, como no famoso ditado de Sunstein e Holmes, "levar os direitos a sério significa levar a escassez a sério ${ }^{408}$ ".

Segundo Wanderley Guilherme dos Santos, é possível falar na existência de quatro graus de escassez dos recursos públicos ${ }^{409}$. A mais benigna é a escassez moderada, situação onde o Estado dispõe de recursos suficientes para prosseguir na execução dos programas existentes e assumir compromissos substanciais em relação a novos programas. Na escassez crônica, existem recursos para manter os programas existentes e expandi-los moderadamente, mas não existem recursos para dar início a programas mais amplos. As dificuldades decisórias se intensificam quando há uma situação de escassez aguda. Na escassez aguda, não existem recursos para aumentar os programas existentes, e são necessários cortes orçamentários em alguns programas. Finalmente, existe a escassez total, situação na qual o Estado não dispõe de recursos para executar nem mesmo os seus programas básicos.

Para Wanderley Guilherme dos Santos, essa análise quantitativa da escassez deve ser acompanhada de uma análise qualitativa: além da escassez de recursos, é necessário analisar a escassez de bens, serviços e mão-de-obra necessários para o desempenho das atividades estatais ${ }^{410}$. Um país com escassez de médicos terá muito mais dificuldades para estruturar uma rede pública de saúde eficaz. Um medicamento atualmente escasso pode se tornar extremamente acessível no futuro. Da mesma forma, os esforços estatais para tornar os serviços de banda larga disponíveis para a população de baixa renda seriam impensáveis há alguns anos atrás.

Wanderley Guilherme dos Santos propõe então a substituição da variável escassez pela variável estrutura da escassez, que atende aos aspectos quantitativos e qualitativos do problema e que varia continuamente, até mesmo como resultado das

\footnotetext{
${ }^{407}$ CASTRO; RIBEIRO; CAMPOS e MATIJASCIC, “A CF/88 e as Políticas Sociais Brasileiras”, p. 101. 408 "Taking rights seriously means taking scarcity seriously". Cass SUNSTEIN e Stephen HOLMES, The Cost Of Rights: why liberty depends on taxes. New York: W.W. Norton \& Company, 1999, p. 94.

${ }^{409}$ Wanderley Guilherme dos SANTOS, Cidadania e Justiça: a política social na ordem brasileira, pp. 61-62.

${ }^{410}$ Wanderley Guilherme dos SANTOS, Cidadania e Justiça, p. 62-63.
} 
decisões políticas anteriores ${ }^{411}$. A desconsideração dos aspectos qualitativos da escassez seria enganadora, ao tornar homogêneas, sob a forma de magnitudes monetárias comparáveis, situações estruturalmente distintas. À medida que a estrutura da escassez se modifica, o mundo aparece de maneira distinta para os tomadores de decisão, o que permite mudar a orientação das políticas existentes, mesmo que não haja alteração significativa na estrutura político-partidária ${ }^{412}$.

A modificação da estrutura da escassez altera não só as possibilidades de atuação do Estado, mas também as demandas do público. Os diferentes setores do público reagem de maneira distinta à modificação da estrutura da escassez, de acordo com a percepção do lugar que ocupam na estrutura social e os padrões de justiça que sustentam $^{413}$. A disponibilidade de novos recursos implica que os diversos os setores do público pressionarão o Estado a alocá-los de acordo com as suas preferências. A estrutura da opinião pública é uma variável interveniente entre a estrutura da escassez e o conteúdo das decisões políticas ${ }^{414}$.

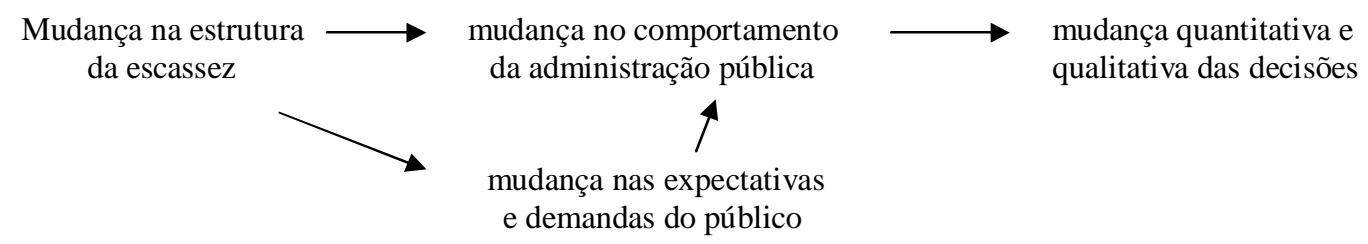

Figura 2. Estrutura da escassez, público e administração pública.

A atuação estatal é dependente da disponibilidade de recursos em todas as suas frentes. Como as normas de direitos fundamentais possuem suporte fático amplo ${ }^{415}$, praticamente toda atividade estatal pode ser considerada uma atividade de concretização dos direitos fundamentais (ou uma atividade que se desvia dessa concretização ${ }^{416}$ ). E

\footnotetext{
${ }^{411}$ Wanderley Guilherme dos SANTOS, Cidadania e Justiça, p. 62-63.

${ }^{412}$ Wanderley Guilherme dos SANTOS, Cidadania e Justiça, p. 62-63.

${ }^{413}$ Wanderley Guilherme dos SANTOS, Cidadania e Justiça, p. 62-63.

${ }^{414}$ Wanderley Guilherme dos SANTOS, Cidadania e Justiça, p. 64.

${ }^{415}$ Para o conceito de suporte fático amplo, Virgílio Afonso da SILVA, Direitos Fundamentais: conteúdo essencial, restrições e eficácia, p. 108 e ss.

${ }^{416}$ A idéia de que a atuação estatal pode rejeitar ou deturpar a concretização dos direitos fundamentais e das normas programáticas é defendida por Marcelo Neves. A Constitucionalização Simbólica, p. 115.
} 
todos os direitos fundamentais possuem custos, sejam eles liberdades públicas, direitos políticos, direitos sociais ou direitos difusos, coletivos e transindividuais ${ }^{417}$. O exercício das liberdades públicas é dependente da criação e manutenção da polícia e de registros públicos de propriedade (material e intelectual), dentre outras atividades estatais ${ }^{418}$. O exercício dos direitos políticos é dependente da criação e manutenção de câmaras legislativas e de cartórios eleitorais, da realização de eleições, referendos, plebiscitos e consultas e da proteção dos fluxos comunicativos da esfera pública ${ }^{419}$. O exercício dos direitos difusos, coletivos ou transindividuais, como o direito ao meio ambiente ecologicamente equilibrado ( $\mathrm{CF}$, art. 225), da mesma forma, é dependente da criação de órgãos que fiscalizam e punem os descumpridores.

Os direitos fundamentais sociais não fogem a essa lógica, já que a sua concretização é dependente de políticas públicas como a política educacional, a política de saúde, a política de habitação e a política de assistência social. Os custos envolvidos na sua realização, no entanto, são bem maiores se comparados aos custos dos demais direitos, pois as políticas públicas sociais demandam uma infra-estrutura mais cara e mais especializada.

A criação das condições de exercício dos direitos sociais é, pura e simplesmente, mais cara. Isso porque essas condições, além de incluir tudo aquilo que é necessário para produção de efeitos das liberdades públicas - proteção, organizações, procedimentos, etc. - exige algo mais. E esse algo mais, além de pressupor recursos financeiros não disponíveis, costuma ser específico para cada um dos direitos sociais, o que aumenta ainda mais os seus custos. Assim, enquanto boa parte dos custos das liberdades públicas são aproveitados de maneira global por todas elas - legislação, organização judiciária, etc. - cada direito social exige uma prestação estatal exclusiva que só é aproveitada na sua realização, mas não na realização de outros. Nesse sentido, a construção e a manutenção de hospitais, contratação de médicos, compra de caros materiais hospitalares, organização de programas de combate a epidemias, entre outras coisas, só são aproveitadas para a realização de um único direito social, o direito à saúde. O mesmo vale para a construção e a manutenção de escolas, contratação de professores, compra de

${ }^{417}$ Cass SUNSTEIN e Stephen HOLMES, The Cost Of Rights: why liberty depends on taxes. Ingo Wolfgang SARLET e Luciano Benetti TIMM (Orgs.), Direitos Fundamentais: orçamento e reserva do possível. Gustavo AMARAL, Direito, Escassez e Escolha. São Paulo: Renovar, 2001.

${ }^{418}$ Cass SUNSTEIN e Stephen HOLMES, The Cost Of Rights.

${ }^{419}$ Cass SUNSTEIN e Stephen HOLMES, The Cost Of Rights. 
material escolar e de alimentos para a merenda, organização de programas de aperfeiçoamento didático para professores, no caso do direito à educação; de construção de casas e abertura de créditos habitacionais, no caso do direito à moradia ${ }^{420}$.

Por serem mais caros, as perguntas sobre o grau de exigibilidade dos direitos sociais são muito mais freqüentes do que as perguntas sobre o grau de exigibilidade dos demais direitos fundamentais. Até que ponto um cidadão pode exigir judicialmente que o Estado the forneça uma prestação social específica, como um tratamento médico ou uma moradia? Quais os limites dessa exigibilidade, visto que os recursos estatais são escassos? O Estado deve garantir um mínimo existencial, independentemente das suas restrições orçamentárias? Em caso afirmativo, qual seria a sua extensão $?^{421}$

Trata-se de questões amplamente controversas e que nos últimos anos têm sido responsáveis pelas já mencionadas tensões entre a política e o direito (a judicialização da política e a politização do judiciário). O sistema político e o sistema jurídico interpretam a questão de maneira distinta e até mesmo incompatível. Não só a lógica coletiva e impessoal com a qual a administração pública elabora as políticas públicas colide com a noção de prestações judicialmente exigíveis por cada indivíduo como as limitações orçamentárias do Estado se chocam frontalmente com insistente desconsideração de fatores orçamentários pelas decisões judiciais ${ }^{422}$.

A positivação dos direitos sociais e sua judicialização tornam ainda mais exposta a fragilidade do Estado Democrático de Direito frente ao fenômeno da escassez. Conforme bem assevera Celso Campilongo, essa fragilidade é ainda mais evidente na modernidade periférica. Enquanto em uma pequena cidade de um país central optar pela construção de uma escola implica rejeitar a construção de um teatro ou de um hospital, em uma cidade da modernidade periférica essa escolha também implica renunciar a gastos com saneamento básico, pavimentação de ruas, construção de casas populares,

\footnotetext{
${ }^{420}$ Virgílio Afonso da SILVA, Direitos Fundamentais: conteúdo essencial, restrições e eficácia, pp. 241242.

${ }^{421}$ Para uma exposição e defesa normativa do mínimo existencial, Ricardo Lobo TORRES, O Mínimo Existencial, os Direitos Sociais e os Desafios de Natureza Orçamentária.

${ }^{422}$ Novamente, a opinião de Virgílio Afonso da Silva: "a dificuldade de obter uma tutela jurisdicional satisfatória no âmbito dos direitos sociais reside no caráter coletivo desses direitos. Ainda que se possa dizer que cada indivíduo tenha um direito à saúde, um direito à educação, ao trabalho e à moradia, a realização desses direitos é algo que só é possível se pensada coletivamente. Os procedimentos judiciais, sobretudo no Brasil, não estão, contudo, aptos a dar vazão a pretensões judiciais dessa natureza. Todo direito processual é pensado - e as raríssimas exceções não mudam esse quadro - para uma litigância individual”. Direitos Fundamentais: conteúdo essencial, restrições e eficácia, pp. 243.
} 
combate à desnutrição infantil e uma infinidade de outras necessidades prementes ${ }^{423}$. Cada escolha realizada exclui um número maior de alternativas igualmente importantes.

Os países periféricos, especialmente os países democráticos da nova periferia como Brasil, enfrentam dificuldades muito maiores para lidar com o fenômeno da escassez e promover a inclusão social da população do que os países da modernidade central. É preciso ressaltar que o Estado Democrático e Social de Direito se encontra submetido a dois imperativos funcionais conflitantes: garantir as condições políticas de reprodução da acumulação privada e ao mesmo tempo tomar medidas redistributivas que visam minimizar a desigualdade oriunda do processo de acumulação. O segundo objetivo se torna viável apenas na medida em que o primeiro é bem sucedido, "fornecendo os recursos necessários para as políticas de bem-estar social e limitando a extensão das reivindicações relativas a esses recursos ${ }^{424}$,. No Brasil, essa tendência é confirmada por Castro, Ribeiro, Campos e Matijascic, para quem

[...] é flagrante o movimento dos gastos sociais conexo ao ciclo econômico. Nos momentos de recessão, como no início dos anos 1980 e também no início dos anos 1990, o gasto social sofre restrições à sua manutenção, enfrentando não apenas estagnação, mas inclusive reduções em termos do percentual do PIB. Entre outras razões, isso ocorre, no plano federal, pela implantação de severos regimes fiscais e, no plano estadual, o impacto da desaceleração econômica é avassalador sobre a sua arrecadação, pautada no Imposto sobre Circulação de Mercadorias e Prestação de Serviços (ICMS). ${ }^{425}$

O principal mecanismo para a consecução desses objetivos é a tributação, enquanto mecanismo de captação de recursos junto aos particulares e enquanto mecanismo de redistribuição, através da progressividade tributária (os tributos são pagos de acordo com a capacidade contributiva de cada um: os mais ricos pagam mais tributos e os mais pobres, menos tributos ${ }^{426}$ ). A tributação dos recursos dos particulares

\footnotetext{
${ }^{423}$ Celso Fernandes CAMPILONGO, Política, Sistema Jurídico e Decisão Judicial. São Paulo, Max Limonad, 2002, pp. 169-170.

${ }^{424}$ Claus OFFE, Problemas Estruturais do Estado Capitalista, p. 378.

${ }^{425}$ Claus OFFE, Problemas Estruturais do Estado Capitalista, p. 97.

426 Trata-se de um princípio institucionalizado nas democracias liberais e largamente comentado (sob o ponto de vista jurídico-normativo) pelos estudiosos do direito tributário. Segundo Roque Antônio Carrazza, "o princípio da capacidade contributiva hospeda-se nas dobras do princípio da igualdade e
} 
não pode danificar o processo de acumulação, pois é esse processo que garante a existência de recursos tributáveis, e o mau desempenho da economia é um significativo fator de deslegitimação. Da mesma forma, a acumulação privada não pode esquivar-se de ser tributada para a promoção de medidas redistributivas, principalmente quando a administração é pressionada nesse sentido pela esfera pública ${ }^{427}$.

Nos países democráticos da nova periferia, essas pressões são particularmente intensas, pelos seguintes motivos. Em primeiro lugar, nesses países inexiste uma esfera moral autônoma e consensual capaz de garantir a estabilidade de uma ordem social profundamente desigual, como no sistema indiano de castas e nas teocracias islâmicas ${ }^{428}$. O controle do acesso desigual aos recursos da sociedade pela naturalização religiosa ou ideológica da desigualdade é demasiado frágil. Isso faz com que a tarefa de produzir a legitimação da ordem social seja deslocada para as esferas política e jurídica $^{429}$.

Em muitos desses países periféricos, a redemocratização foi marcada pela emergência de uma esfera pública atuante e capaz de exercer pressão efetiva sobre a administração pública ${ }^{430}$. No Brasil, as pressões para a realização de gastos sociais

ajuda a realizar, no campo tributário, os ideais republicanos. Realmente, é justo e jurídico que quem, em termos econômicos, tem muito pague, proporcionalmente, mais imposto do que quem tem pouco. Quem tem maior riqueza deve, em termos proporcionais, pagar mais imposto do que quem tem menor riqueza". Curso de Direito Constitucional Tributário. São Paulo: Malheiros, 2006, p. 86.

427 "The government budget [...] bears the costs of imperialistic market strategies and the costs of demand for unproductive commodities (armaments and space travel). It bears the infrastructural costs directly related to production (transportation and communication systems, scientific-technical progress, vocational training). It bears the costs of social consumption indirectly related to production (housing construction, transportation, health care, leisure, education, social security). It bears the costs of social welfare, especially unemployment. And, finally, it bears the externalized costs of environmental strain arising from private production. In the end, these expenditures have to be financed through taxes. The state apparatus is, therefore, faced simultaneously with two tasks. On the one hand, it is supposed to raise the requisite amount of taxes by skimming off profits and income and to use the available taxes so rationally that crisis-ridden disturbances of growth can be avoided. On the other hand, the selective raising of taxes, the discernible pattern of priorities in their use, and the administrative performances themselves must be so constituted that the need for legitimation can be satisfied as it arises. If the state fails in the former task, there is a deficit in administrative rationality. If it fails in the latter task, a deficit in legitimation results". Jürgen HABERMAS, Legitimation Crisis, pp. 61-62.

428 Jessé Souza. A Construção Social da Subcidadania.

429 Em sentido análogo, se referindo às sociedades pós-tradicionais de maneira geral, Jürgen HABERMAS, Faktizität und Geltung: Beiträge zur Diskurtheorie des Rechts und des demokratischen Rechtsstaats.

${ }^{430}$ No caso do brasileiro, essa tendência se iniciou na década de 1970. Mesmo com a repressão praticada pelo regime militar, já na década de 1970 alguns movimentos se organizaram em torno de reivindicações urbanas, como a educação, saúde, moradia, saneamento e transporte coletivo. Nesse período, despontaram as Comunidades Eclesiais de Base (CEB) e o movimento operário do ABC. Em 1979, acontece o congresso de refundação da União Nacional dos Estudantes (UNE) e no início dos anos 1980 nascem a Central Única dos Trabalhadores (CUT) e o Movimento dos Trabalhadores Rurais Sem-Terra (MST). Na década de 1990, ocorre a proliferação das ONGs. "Avanços e Desafios da Participação Social na Esfera 
advêm tanto de setores organizados do público, como os movimentos sociais, quanto dos tribunais, constantemente chamados a produzir decisões sobre o conteúdo das políticas públicas. A legitimação do Estado brasileiro se encontra altamente atrelada ao discurso da cidadania e dos direitos sociais, isto é, os gastos sociais estão diretamente relacionados ao apoio específico ao governo e ao apoio difuso ao sistema político ${ }^{431}$.

Mesmo que uma política que privilegie as medidas de fomento à acumulação privada em detrimento das medidas redistributivas - a chamada política de gotejamento ou trickle down ${ }^{432}$ - fosse adequada sob o ponto de vista macroeconômico, ela se mostra inviável sob o ponto de vista político, em função da composição da opinião pública brasileira. A ausência de níveis considerados satisfatórios de gasto social é um risco político a ser assumido. Soma-se a esse fato a mudança na estrutura da escassez vivenciada a partir da redemocratização, que passou de uma situação de escassez aguda para uma situação de escassez moderada, em função (i) do aumento da carga tributária, (ii) do equilíbrio da balança de pagamentos e (iii) da retomada do crescimento econômico, após a estagflação da década de 1980 e do início da década de 1990.

Como os recursos para a promoção de medidas redistributivas são obtidos primordialmente através da tributação dos particulares, o Estado Democrático de Direito se vê diante da necessidade de realizar aquilo que Wanderley Guilherme dos Santos denomina cálculo do dissenso tolerável. Trata-se do equilíbrio entre a quantidade de desigualdade e exclusão a ser socialmente tolerada, em favor do processo de acumulação e, ao mesmo tempo, entre a quantidade de recursos para combater a desigualdade e a exclusão que podem ser subtraídos do processo de acumulação, sem prejudicar a sua reprodução.

Pública Federal Brasileira”. In Brasil em Desenvolvimento: Estado, Planejamento e Políticas Públicas. Volume I. Brasília: IPEA, 2009, p. 800.

${ }^{431} \mathrm{O}$ estudo empírico realizado por Alessandra Aldé constatou que "os mais pobres reclamam uma democracia mais "completa" ou "real", capaz de minimizar a desigualdade e seus efeitos. Nesse sentido, percebemos uma demanda por igualdade que vai além da equiparação jurídica e política, mas indica uma aspiração à distribuição mais justa da riqueza, um bem-estar material assegurado pelo Estado". Alessandra ALDÉ, A Construção da Política: cidadão comum, mídia e atitude política. Rio de Janeiro: tese de doutorado (IUPERJ), 2001, p. 49.

${ }^{432}$ Para uma ampla discussão sobre a política de gotejamento, Malla POLLACK, "O Alto Custo de Não se ter Direitos Positivos, uma Perspectiva dos Estados Unidos". In SARLET e TIMM (Orgs.), Direitos Fundamentais: orçamento e reserva do possível, pp. 363-389. 
As imposições da dinâmica dos conflitos, por um lado, e as necessidades de garantir a reprodução ampliada (acumulação) da riqueza social, por outro, induzem os governos a exercitar permanentemente o que se poderia chamar de "cálculo do dissenso" [...], isto é, a taxa de injustiça, em favor da acumulação, que será socialmente tolerada ou, conversamente, a magnitude dos recursos que se podem subtrair à acumulação, em favor da equidade, sem prejuízo catastrófico para o processo ampliado de reprodução. Em qualquer caso, a solução de satisfação/insatisfação política não será homogeneamente distribuída pela sociedade, de onde resulta apropriado falar-se em "cálculo do dissenso" tolerável como parâmetro fundamental para as decisões governamentais, quero dizer, de todo e qualquer governo ${ }^{433}$.

A análise de Wanderley Guilherme dos Santos pode ser interpretada como uma tentativa de substancializar a atuação da legitimidade como fórmula de contingência a partir de um contexto específico: o dos conflitos redistributivos nos Estados de BemEstar. O cálculo do que o público está disposto a aceitar é, em grande medida, o cálculo do equilíbrio entre medidas de fomento à acumulação e medidas redistributivas. $\mathrm{O}$ binômio acumulação/redistribuição não é passível de solução ou superação na sociedade capitalista, mas somente de gerenciamento, a partir de um cálculo marginalista. Diante da inexistência do bem comum e da impossibilidade de distribuir homogeneamente a satisfação e a insatisfação, é preciso calcular a quem agradar e desagradar, e em que medida $^{434}$.

Em países com alto índice de exclusão e desigualdade, esse cálculo se torna mais problemático em função da maior heterogeneidade dos interesses presentes na esfera pública $^{435}$ e da maior quantidade de recursos necessária para a promoção da inclusão (nos países com menos excluídos e subincluídos, obviamente são necessários menos

\footnotetext{
${ }^{433}$ Wanderley Guilherme dos SANTOS, Cidadania e Justiça, p. 125. Claus Offe, de maneira análoga, a partir de um diagnóstico neomarxista, identifica a origem do cálculo do dissenso tolerável no pacto fundador do welfare state, ao afirmar que "cada classe tem que levar em consideração os interesses da outra classe: os operários, a lucratividade, porque somente um nível de lucro e de investimento razoável garantirá o emprego futuro e o aumento da renda, e os capitalistas, os salários e despesas do welfare state, porque são eles que garantirão uma demanda efetiva e uma classe operária saudável, bem treinada, sem problemas de moradia e feliz". Problemas Estruturais do Estado Capitalista, pp. 373-374.

${ }^{434}$ Não sem razão, a idéia de bem comum, amplamente utilizada no discurso político do Estado absolutista e liberal, se mostrou insatisfatória como fórmula de contingência do sistema político. Acerca disso: Niklas LUHMANN, Die Politik der Gesellschaft, pp. 120 e ss.

${ }^{435}$ Enquanto nos Estados Unidos a legitimidade da propriedade privada nunca é discutida em sessões legislativas, por exemplo, ela é freqüentemente questionada nos parlamentos dos Estados periféricos. Marcelo NEVES, A Constitucionalização Simbólica, pp. 124-125.
} 
recursos para promover a sua inclusão). Além disso, na medida em que os recursos econômicos são incapazes de satisfazer as demandas dos excluídos e subincluídos, "surge o dilema entre imunizar o Estado contra essas reivindicações ou prejudicar o processo de acumulação ${ }^{436, "}$.

No Brasil, mais especificamente, (i) a redemocratização reestruturou as expectativas do público no sentido de demandar mais gastos sociais do Estado; (ii) a ordem constitucional de 1988 disseminou a cultura da justiciabilidade dos direitos fundamentais, inclusive dos direitos sociais, e os tribunais têm produzido constantemente decisões que obrigam a administração pública à realização de gastos sociais. Ao mesmo tempo, (iii) o aumento da carga tributária a partir de 1988 fez crescer o descontentamento de setores do público com a política fiscal (principalmente da classe média e do setor produtivo), já que esses setores consideram que o aumento dos gastos públicos não é empregado em prol dos seus interesses, e constitui ele mesmo um problema a ser combatido.

A carga tributária considerada excessiva cria divisões profundas na opinião pública. Mesmo que os $10 \%$ mais pobres paguem 44,5\% mais impostos do que os $10 \%$ mais ricos em função da composição da carga tributária ${ }^{437}$, as críticas ao sistema tributário e ao excesso de gastos públicos - principalmente aos programas de transferência direta de renda - se originam principalmente do setor produtivo e das classes mais abastadas (e obviamente dos economistas liberais). Essa posição é reforçada pela percepção generalizada da má qualidade dos serviços públicos. Para Celso Martone, “os cidadãos pagam uma carga tributária explícita de 37\% da renda total e uma carga tributária implícita bem maior, se considerarmos pelo menos parte dos gastos privados com bens públicos que o governo deveria fornecer (justiça, segurança, saúde, educação, transporte, cultura, etc.)". 438

A classe média e a classe alta não costumam utilizar os serviços públicos de saúde, transporte e educação (exceto o ensino superior), preferindo adquirir essas prestações de particulares. Ao mesmo tempo, a população de baixa renda se conscientiza da aviltante desigualdade de benefícios e oportunidades gerada pela má

\footnotetext{
${ }^{436}$ Jürgen HABERMAS, Legitimation Crisis, p. 65.

${ }^{437}$ Receita Pública: quem paga e como se gasta no Brasil. Brasília: IPEA, 2009.

${ }^{438}$ Celso MARTONE, "Instituições, Setor Público e Desenvolvimento: o caso do Brasil". Informações Fipe, 327, 2007, pp. 18-19.
} 
qualidade dos serviços públicos, bem como da contradição entre as promessas de concretização dos direitos fundamentais e a persistência de uma realidade profundamente desigual e excludente.

\subsection{Os Limites da Legitimidade do Estado Democrático de Direito no Brasil.}

O aumento dos gastos sociais no Brasil não foi seguido do pacto social típico do Estado de Bem-Estar. Embora a carga tributária brasileira seja uma das maiores do mundo e comparável à dos Estados de Bem-Estar europeus, a percepção generalizada é a de que ela não se traduz em serviços públicos de qualidade. Com isso, alguns setores do público deixam de aceitar a alta carga tributária. A alta evasão fiscal, a alta informalidade e certas formas de criminalidade são compreendidas pelo público como "mecanismos de defesa contra um Estado cleptocrático". ${ }^{439}$ A informalidade, antes restrita à mão-de-obra com baixa qualificação, hoje se dissemina entre a mão-de-obra qualificada, seja diretamente ou através de mecanismos como a "pejotização", celebração de um contrato entre duas pessoas jurídicas com o intuito de mascarar a existência de uma relação de emprego ${ }^{440}$.

Ao mesmo tempo, parte do público deixa de aceitar a acumulação privada e o apoio dado a ela pelo Estado. Os últimos vinte anos são marcados pela emergência de movimentos sociais que contestam o capitalismo e que nem sempre atuam nas margens da legalidade. Esses movimentos constituem os mais claros indicadores dos limites da legitimidade do Estado Democrático de Direito no Brasil. Para eles, a desobediência civil é compreendida como estratégia para vencer a indiferença da esfera pública e como forma de manifestar a descrença na impossibilidade de satisfazer as suas demandas através dos procedimentos estatais e dentro dos limites permitidos pelo direito.

\footnotetext{
${ }^{439}$ Celso MARTONE, "Instituições, Setor Público e Desenvolvimento: o caso do Brasil”, p. 20.

${ }^{440}$ Ver art. $3^{\circ}$ e art. $9^{\circ}$ da CLT. Essa prática, vedada pela legislação trabalhista, é amplamente comentada pelos estudiosos do direito do trabalho. Por todos, Maurício Godinho DELGADO, Curso de Direito do Trabalho. São Paulo: LTR, 2005, p. 291. A legislação trabalhista brasileira é uma das mais atingidas pelo fenômeno da legislação simbólica.
} 
É preciso ressaltar também que setores considerados de direita têm pregado abertamente a sabotagem dos procedimentos estatais e a ruptura com a ordem constitucional de 1988. Celso Martone, por exemplo, questiona se é possível, pela via democrática, reformar as instituições para que elas se aproximem mais do paradigma por ele defendido. Após chegar a uma conclusão negativa, Martone defende, com o respaldo de "alguns juristas", uma ampla revisão constitucional, feita por uma assembléia constituinte. Curiosamente, logo após negar a via democrática, Martone afirma que "nada pode haver de mais democrático". ${ }^{441}$ Trata-se de mais uma evidência de dissenso de segundo grau e, portanto, de ilegitimidade.

Incapaz de "uma superação ou controle satisfatório da questão social ${ }^{442 \%, ~ o ~ p a i ́ s ~}$ se transforma em algo muito próximo daquilo que Samuel Huntington chama de "sociedade pretoriana". As localidades pretorianas são caracterizadas pela instabilidade institucional, pelo baixo grau de aceitação dos procedimentos estatais e pelo fato de a diferenciação funcional não ter sido seguida da estabilização de instituições políticas e jurídicas suficientemente complexas ${ }^{443}$.

\begin{abstract}
Numa sociedade pretoriana [...], não só os atores variam como também os métodos usados para o preenchimento dos cargos e a determinação das políticas. Cada grupo utiliza dos meios que refletem sua natureza peculiar e suas capacidades. Os ricos subornam; os estudantes se amotinam; os operários fazem greve; as massas promovem manifestações e os militares efetuam golpes. $\mathrm{Na}$ ausência de procedimentos reconhecidos, todas essas formas de ação direta são encontradas no cenário político ${ }^{444}$.
\end{abstract}

Os procedimentos estatais, freqüentemente sabotados pela atuação das mais diversas forças sociais, enfrentam claros limites à sua capacidade de absorver os

${ }^{441}$ Celso MARTONE, "Instituições, Setor Público e Desenvolvimento: o caso do Brasil”. A passagem relativa à revisão constitucional existe apenas em uma versão anterior do trabalho, e foi suprimida na versão resumida, publicada na Revista Fipe. A afirmação sobre a impossibilidade de transformação institucional pela via democrática pode ser encontrada em ambas as versões.

${ }^{442}$ Marcelo NEVES, A Constitucionalização Simbólica, p. 125.

443 Samuel HUNTINGTON, A Ordem Política nas Sociedades em Mudança. Tradução de Pinheiro de Lemos. São Paulo: Forense Universitária, 1975. A tese de Huntington não é adotada aqui em sua totalidade. Para uma crítica a essa tese: Enrique PERUZZOTTI, "Modernization and Juridification in Latin America: a reassessment of the latin american developmental path", pp. 67 e ss. Tércio Sampaio FERRAZ JR., Estudos de Filosofia do Direito: reflexões sobre o poder, a liberdade, a justiça e o direito. São Paulo: Atlas, 2003, pp. 280 e ss.

${ }^{444}$ Samuel HUNTINGTON, A Ordem Política nas Sociedades em Mudança, p. 208. 
conflitos e dissensos existentes na sociedade e intermediá-los através da produção de decisões. Inúmeras decisões produzidas pela administração pública não obtêm vinculação coletiva. Incapaz de restringir o comportamento dos cidadãos às opções juridicamente permitidas, a administração pública é obrigada a mobilizar com maior frequiência e intensidade o seu potencial coercitivo para forçar o cumprimento da lei em casos específicos (ou então permitir que elas sejam sistematicamente descumpridas).

O Estado Democrático de Direito no Brasil enfrenta não só um baixo nível de apoio específico, como também um baixo nível de apoio difuso. O país possui o terceiro menor nível de apoio ao regime democrático dentre os países latino-americanos: $40 \%$ de democratas, sendo superado apenas pelo Equador $(36,1 \%)$ e Paraguai $(38,6 \%) .{ }^{445}$ Embora o índice de cidadãos abertamente autoritários seja baixo, 54\% da população é considerada ambivalente ${ }^{446}$. Os ambivalentes não se opõem abertamente à democracia, mas apóiam medidas autoritárias como o fechamento do congresso e dos partidos políticos. Embora os indivíduos autoritários sejam os mais identificados com valores antidemocráticos, a incerteza dos ambivalentes reforça atitudes que dificultam ou bloqueiam a aceitação da democracia.

Para José Álvaro Moisés, essas opiniões são indicadores de "insatisfação com o regime e de desconfiança das instituições ${ }^{447}$ ". Os autoritários e ambivalentes consideram com muito mais freqüência que a democracia não corresponde às expectativas criadas durante o processo de democratização (o grau de insatisfação também é alto entre os democratas, que exigem um modelo democrático aperfeiçoado). Embora seja pouco provável que isso coloque em risco a sobrevivência da democracia e dos sistemas funcionais, a má percepção acerca do regime democrático afeta tanto a capacidade do sistema político de produzir decisões coletivamente vinculantes quanto a capacidade do sistema jurídico de fornecer expectativas seguras.

O estudo de José Álvaro Moisés, baseado em dados coletados pelo Instituto Latinobarômetro, corrobora algumas conclusões da tradição estadunidense da justiça procedimental (expostas no segundo capítulo), confirmando a importância dos procedimentos como mecanismos de absorção do dissenso e de legitimação do Estado Democrático de Direito. Moisés concluiu que o desempenho econômico do governo não

\footnotetext{
${ }^{445}$ José Álvaro MOISÉS, “Cultura Política, Instituições e Democracia”, p. 23.

${ }^{446}$ José Álvaro MOISÉS, "Cultura Política, Instituições e Democracia”, p. 23.

${ }^{447}$ José Álvaro MOISÉS, “Cultura Política, Instituições e Democracia”, p. 30.
} 
afeta de maneira significativa o apoio difuso, embora reconheça que esta seja "uma área que demanda mais pesquisa ${ }^{448}$ ". A análise de Moisés corrobora a afirmação da tradição da justiça procedimental de que o nível de apoio difuso não é afetado apenas por considerações instrumentais (cálculo de maximização dos benefícios individuais), como sugerem as teorias da escolha racional baseadas na teoria econômica da democracia de Downs. $^{449}$

O apoio difuso às instituições depende tanto das "orientações formadas durante processos originários de socialização" quanto das experiências diárias dos cidadãos com as instituições ${ }^{450}$. As considerações sobre a qualidade dos procedimentos (justiça procedimental) e a qualidade geral dos resultados por eles produzidos (justiça distributiva) possuem um impacto considerável sobre o apoio difuso e sobre a preferência por comportamentos que se mantêm nos limites permitidos pelo direito. A percepção sobre a injustiça dos procedimentos (a sua falta de equidade, de confiabilidade e de acessibilidade) cria a sensação de que resultados melhores poderiam ser obtidos em outras condições.

Infelizmente, as ciências sociais brasileiras ainda são carentes de estudos sobre a justiça procedimental, voltados a analisar como as especificidades da realidade brasileira (como o personalismo, a exclusão e a corrupção generalizadas) afetam o apoio difuso ao sistema e o apoio específico aos governantes (o estudo de José Álvaro Moisés e a pesquisa do Instituto Latinobarômetro não distinguem com clareza as avaliações substanciais feitas pelos cidadãos das avaliações procedimentais). As considerações feitas a seguir, portanto, possuem um caráter predominantemente compreensivo e hipotético.

A exclusão afeta negativamente a competência para o desempenho de papéis (role competence), pois se manifesta justamente como negação do exercício dos papéis sociais relevantes aos excluídos. A role competence é a capacidade para processar as informações relativas aos papéis sociais que são política e juridicamente relevantes, e

\footnotetext{
${ }^{448}$ José Álvaro MOISÉS, “Cultura Política, Instituições e Democracia”, p. 38

${ }^{449}$ Anthony DOWNS, Uma Teoria Econômica da Democracia. São Paulo: EDUSP, 2001.

450 “[...] A mescla entre orientações valorativas e orientações pragmáticas - derivadas do julgamento do desempenho das instituições - cria o ambiente em que se definem as atitudes e as percepções intersubjetivas dos indivíduos quanto ao regime político". José Álvaro MOISÉS, "Cultura Política, Instituições e Democracia", p. 18.
} 
pressupõe a compreensão dos direitos e deveres dos cidadãos ${ }^{451}$. Segundo Luhmann, a exclusão não gera propriamente criminalidade, mas a indiferença dos excluídos em relação ao código jurídico (a diferença entre o lícito e o ilícito). ${ }^{452}$ A internalização desses papéis sociais não implica um comportamento acrítico, pois a própria crítica depende da compreensão dos direitos e deveres e do exercício do papel de público na esfera pública.

\section{Para José Álvaro Moisés,}

Confiar em instituições supõe conhecer a idéia básica ou a função permanentemente atribuída a elas pela sociedade [...]. Isso se explicita através das regras constitutivas das instituições que remetem a conteúdos éticos e normativos resultantes da disputa dos atores pelo sentido da política; por isso essas regras são referências tanto da ação dos responsáveis pelas instituições como das pessoas comuns que se orientam, a partir da sua experiência, por aquilo que aprendem sobre o funcionamento das instituições ${ }^{453}$.

A exclusão e o personalismo prejudicam a distinção entre questões substanciais e questões procedimentais (que depende da concentração da formação das expectativas sociais nos planos intermediários dos papéis e das regras, e não nos planos das pessoas e valores, principalmente se esses valores forem a prestância e a rivalidade), fundamental para a legitimação pelo procedimento. ${ }^{454} \mathrm{Na}$ ausência de apoio difuso, o Estado Democrático de Direito se faz altamente dependente do apoio específico dado a governantes individualmente considerados. A ausência de consenso procedimental aumenta a dependência do conteúdo das decisões e do discurso simbólico políticolegitimador. A invocação da legalidade se torna incapaz de produzir a aceitação das

\footnotetext{
${ }^{451}$ Robert GRAFSTEIN, “The Legitimacy of Political Institutions”, p. 64. Ver as considerações feitas no segundo capítulo do presente trabalho.

452 "La penuria produce una gran indiferencia ante el codigo juridico legal/ilegal (lo que tiene que ser interpretado como indiferencia y no, por ejemplo, como predilección por la criminalidad)". Niklas LUHMANN, Inclusión y Exclusión, p. 191. No mesmo sentido, Orlando VILLAS BÔAS FILHO, Teoria dos Sistemas e o Direito Brasileiro, p. 351 e ss.

${ }^{453}$ José Álvaro MOISÉS, “Cidadania, Confiança e Instituições Democráticas”. Lua Nova, 65, 2005, p. 87.

${ }^{454}$ Sobre a relação entre a legitimação pelo procedimento e a distinção entre questões substanciais e procedimentais, Niklas LUHMANN, Legitimation durch Verfahren, p. 31.
} 
decisões, em razão do exaurimento da confiança no fato de que o Estado contribui para a construção de uma sociedade cada vez melhor, mais justa e segura ${ }^{455}$.

Esse apoio específico não depende apenas de considerações instrumentais sobre o desempenho dos governantes. No Brasil, ele é altamente dependente de considerações personalistas e afetivas, como sugere o estudo de Alessandra Aldé ${ }^{456}$. A crença no líder salvador (salvacionismo), que age com "boa vontade" - e não no exercício de competências legalmente estabelecidas e em respeito à circularidade procedimental do Estado Democrático de Direito - é recorrente entre o público, de modo que "os personagens políticos são transformados em ícones, caricaturas deles mesmos, a partir de referências extremamente subjetivas e, muitas vezes, visuais ${ }^{457}$ ". Essa é apenas mais uma das manifestações do personalismo que inibe a racionalidade dos procedimentos estatais e traz desafios adicionais à legitimação do Estado Democrático de Direito em contextos periféricos como o brasileiro.

\footnotetext{
${ }^{455}$ Ver as considerações de Claus OFFE, Problemas Estruturais do Estado Capitalista, p. 270.

456 "A democracia não seria entendida [...] como uma competição, com regras justas, pela alocação dos recursos comuns, mas de modo mais substantivo, como responsável pelo bem-estar de "todos". Trata-se de um enquadramento que privilegia o discurso personalista, salvacionista, da política nacional e que, como demonstramos nesta tese, tem grande repercussão junto ao cidadão comum”. Alessandra ALDÉ, $A$ Construção da Política, pp. 43-44.

${ }^{457}$ Alessandra ALDÉ, A Construção da Política, p. 89.
} 


\section{CONSIDERAÇÕES FINAIS.}

Mais ce à quoi la réflexion peut et doit servir, c'est à marquer le butqu'il faut atteindre. C'est ce que nous avons essayé de faire.

Émile Durkheim.

Na sociedade hipercomplexa e funcionalmente diferenciada do presente, atenção e consenso constituem recursos escassos. O Estado Democrático de Direito, para se legitimar, necessita fazer-se altamente independente do consenso em torno do resultado das suas decisões. A institucionalização de procedimentos decisórios juridicamente estruturados responde a essa necessidade, na medida em que limita a arbitrariedade das decisões e aumenta a probabilidade de aceitação de conteúdos ainda indeterminados, dentro de certa margem de tolerância.

O mecanismo da institucionalização, por sua vez, permite que o consenso suposto de terceiros seja invocado em cada relação política ou jurídica, em substituição ao consenso real, que é economizado (pois precisa ocorrer somente em momentos 
determinados, com pessoas determinadas e sobre assuntos determinados). ${ }^{458}$ Ainda que os indivíduos divirjam das normas jurídicas, devem supô-las generalizadas socialmente. A função dos procedimentos decisórios, portanto, não é criar consenso, mas economizálo, imunizando o Estado Democrático de Direito contra a ausência de consenso real.

Essa é a realidade, escandalosa para alguns, da política e do direito de uma sociedade que não corresponde aos anseios dos indivíduos e que constitui para eles um problema a ser equacionado. O presente trabalho não faz nenhuma opção pela legitimidade ou pela ilegitimidade, para o desagrado daqueles que buscam a legitimar as instituições vigentes ou daqueles que se recusam a conferir-lhes qualquer legitimidade. Como afirmou Wittgenstein, die Tatsachen gehören alle nur zur Aufgabe, nicht zur Lösung (os fatos pertencem somente ao problema, e não à solução).

O presente trabalho se limita somente a identificar a maneira paradoxal como o dissenso se apresenta no Estado Democrático de Direito. Como a democracia tolera o dissenso e pode inclusive fomentar o seu surgimento, exercer o dissenso dentro dos limites tolerados pelo Estado Democrático de Direito é, de certa maneira, conferir-lhe legitimidade. A ilegitimidade requer não só dissenso em relação aos próprios procedimentos (já que eles permitem essa possibilidade), mas o exercício do dissenso fora dos limites que os procedimentos permitem.

A legitimação pelo procedimento não é uma panacéia capaz de garantir a legitimação de qualquer decisão. A produção contínua de decisões que frustram as expectativas do público prejudica o efeito de intermediação e absorção dos procedimentos, ao expor o excesso de simbolização do poder (o uso de mecanismos dilatórios). Além disso, a falta de lisura, equidade e acessibilidade dos procedimentos generaliza no público a expectativa de que resultados mais justos ou favoráveis poderiam ter sido obtidos sob outras condições ${ }^{459}$.

É justamente isso que acontece no contexto brasileiro. No quarto capítulo, apontamos para a existência generalizada de redes sociais que reproduzem um padrão personalista de interação que prejudica o cumprimento da função do sistema político (a manutenção da capacidade de produção de decisões coletivamente vinculantes) e do sistema jurídico (a generalização congruente de expectativas normativas). A corrupção,

\footnotetext{
${ }^{458}$ Niklas LUHMANN, Sociologia do Direito, Volume I, p. 80.

${ }^{459}$ Tom Tyler, Why People Obey the Law, p. 117.
} 
reproduzida através dessas redes sociais (e não através de interações esporádicas) compromete a incerteza quanto ao resultado dos procedimentos, que se tornam "jogos de cartas marcadas", e a sua equidade.

Os dados demonstram que isso acontece no procedimento eleitoral (não através de fraudes eleitorais, mas através da compra de votos), no procedimento administrativo (fraudes a licitações, corrupção de servidores), no procedimento legislativo (compra de parlamentares) e no procedimento judicial (compra de sentenças e procedimentos). Incapaz de se imunizarem contra essas sobreposições particularistas, o sistema político e principalmente o sistema jurídico passam a sofrer com aquilo que Marcelo Neves denominou allopoiesis (a reprodução do sistema através dos critérios do ambiente, e não através dos seus próprios critérios).

A generalização do código fraco da justiça material e a naturalização das desigualdades $^{460}$ comprometem a equidade dos procedimentos estatais, pois generalizam e naturalizam o tratamento desigual dos excluídos, que se transformam em cidadãos incluídos no direito somente pelo pólo dos deveres, mas não pelo pólo dos direitos. ${ }^{461}$ Os dados demonstram, por exemplo, que as revistas, ofensas e agressões policiais (a polícia é considerada parte do procedimento administrativo) não ocorrem com a mesma freqüência entre as raças ${ }^{462}$.

Em relação à acessibilidade dos procedimentos, cumpre afirmar que os efeitos da exclusão são muito mais profundos que a literatura reconhece. A exclusão - que se manifesta enquanto negação do exercício dos papéis sociais relevantes - compromete a própria competência dos excluídos para o desempenho dos papéis sociais. Sem acesso à informação e pelo fato de terem que se preocupar com as necessidades humanas básicas, pouco tempo e disposição possuem para se inserir nos processos comunicativos políticos ou jurídicos, o que também é demonstrado pelos estudos empíricos ${ }^{463}$. Reduzidos à condição de corpos, os excluídos e subincluídos tornam-se publicamente

\footnotetext{
${ }^{460}$ Jessé SOUZA, A Construção Social da Subcidadania, pp. 164 e ss.

${ }^{461}$ Marcelo NEVES, Entre Têmis e Leviatã: uma relação difícil, pp. 248 e ss.

${ }^{462}$ Dentre as pessoas da raça negra, $48 \%$ já foram revistadas alguma vez por policiais e desses, $21 \%$ foram ofendidas verbalmente e $14 \%$ agredidas fisicamente. Dentre os pardos, $46 \%$ já foram revistados alguma vez e desses, $27 \%$ foram ofendidos e $12 \%$ agredidos. Os brancos são os menos visados pela polícia. 34\% já foram revistados e desses, $17 \%$ foram ofendidos e $6 \%$ agredidos. Pesquisa conduzida pelo Instituto Datafolha. Jornal Folha de São Paulo, 06/04/1997.

${ }_{463}$ Natália BUENO e Francisco FIALHO, "Raça, Desigualdade e Participação Política na Região Metropolitana de Belo Horizonte".
} 
invisíveis, a não ser para a humilhação e a ridicularização (inclusive nos telejornais, como no episódio recente envolvendo um famoso jornalista). ${ }^{464}$

Incumbido de uma dupla tarefa de inclusão (incluir em si mesmo e propiciar as condições para a inclusão nos demais sistemas funcionais ${ }^{465}$ ), ao Estado Democrático de Direito cabe a tarefa de impedir a realização do pior dos cenários imagináveis, a aceitação do código inclusão/exclusão como um metacódigo que perpassa todos os sistemas funcionais, o que implica que "alguns seres humanos serão pessoas e outros apenas indivíduos; que alguns são incluídos nos sistemas funcionais para carreiras (bem sucedidas ou não), enquanto outros são excluídos desses sistemas, constituindo corpos que tentar diariamente sobreviver". ${ }^{466}$ A sua legitimação dependerá do cumprimento dessa tarefa.

\footnotetext{
${ }^{464}$ Fernando Braga da COSTA, Homens Invisíveis: relatos de uma humilhação social. São Paulo: Globo, 2004.

465 Jost HALFMANN, "Der moderne Nationalstaat als Lösung und Problem der Inklusion in das politische System", p. 265.

${ }^{466}$ Niklas LUHMANN, "Globalization or World Society: How to Conceive of Modern Society?".
} 


\section{BIBLIOGRAFIA.}

ABRAMO, Cláudio Weber, "Compra de Votos nas Eleições de 2006, Corrupção e Desempenho Administrativo". Relatório de pesquisa feita pelo IBOPE Opinião para a Transparência Brasil e a União Nacional dos Analistas e Técnicos de Finanças e Controle. $\quad 2007 . \quad$ Fevereiro Disponível em http://www.transparencia.org.br/docs/compravotos2006.pdf

ALDÉ, Alessandra, A Construção da Política: cidadão comum, mídia e atitude política. Rio de Janeiro: tese de doutorado (IUPERJ), 2001.

ALEXY, Robert, Teoria dos Direitos Fundamentais. Tradução de Virgílio Afonso da Silva. São Paulo: Malheiros: 2008.

AMARAL, Gustavo, Direito, Escassez e Escolha. São Paulo: Renovar, 2001.

AMARAL JÚNIOR, Alberto do, Introdução ao Direito Internacional Público. São Paulo: Atlas, 2008.

BANDEIRA DE MELLO, Celso Antônio, Curso de Direito Administrativo. São Paulo: Malheiros, 2007.

BARCELlONA, Pietro, El Individualismo Propietario. Tradução de Jesús Ernesto García Rodríguez. Madrid: Trotta, 1996.

BAUMAN, Zygmunt, Modernidade Líquida. Tradução: Plínio Dentzien. Rio de Janeiro: Jorge Zahar, 2007.

, O Mal-Estar na Pós-Modernidade. Tradução de Mauro Gama e Cláudia Martinelli Gama. Rio de Janeiro: Jorge Zahar, 1998.

BECK, Ulrich, Risikogesellschaft: auf dem Weg in eine andere Moderne. Frankfurt am Main : Suhrkamp, 1986.

BELL, Daniel, The Coming of Post-Industrial Society: a venture in social forecasting. New York: Basic Books, 1976. 
BERCOVICI, Gilberto, Soberania e Constituição: Para uma Crítica do Constitucionalismo. São Paulo: Quartier Latin, 2008.

BITTAR, Eduardo Carlos Bianca, O Direito na Pós-modernidade (e Reflexões Frankfurtianas). Rio de Janeiro: Forense Universitária, 2009.

BLOM, Raimo, (Ed.) (et al.), The Information Society Reader. New York: Routledge, 2001 .

BOBBIO, Norberto, O Futuro da Democracia. São Paulo: Paz e Terra, 2004.

BOMMES, Michael e TACKE, Veronica, “Luhmann's Systems Theory and Network Theory", in: SEIDL, David \& BECKER, Kai (Eds.), Niklas Luhmann and Organizational Studies. Copenhagen: Liber \& Copenhagen Business, 2005, pp. 280302.

BUENO, Natália, e FIALHO, Francisco, "Raça, Desigualdade e Participação Política na Região Metropolitana de Belo Horizonte". 27th Annual ILASSA Conference on Latin America. Austin, 2007.

CALHOUN, Craig (Ed.), Habermas and the Public Sphere. Cambridge, Mass.: MIT Press, 1996.

CAMPILONGO, Celso Fernandes, “A Posição dos Tribunais no Centro e na Periferia do Sistema Mundial”, In SABIDO, Fernando Castañeda e VÁZQUEZ, Angélica Cuéllar (Coord.), Redes de Inclusión: la construcción social de la autoridad. México: Facultad de Ciencias Políticas y Sociales; UNAM; Miguel Ángel PORRÚA, 1998, pp. 55-69. , Política, Sistema Jurídico e Decisão Judicial. São Paulo, Max Limonad, 2002.

CANOTILHO, José Joaquim Gomes, Direito Constitucional. Coimbra: Almedina, 1993.

CARRAZZA, Roque Antônio, Curso de Direito Constitucional Tributário. São Paulo: Malheiros, 2006.

CASTRO, Jorge Abrahão de; RIBEIRO, José Aparecido; CAMPOS, André Gambier e MATIJASCIC, Milko, “A CF/88 e as Políticas Sociais Brasileiras”. In CARDOSO JR., José Celso (org.), A Constituição Brasileira de 1988 Revisitada: recuperação histórica 
e desafios atuais das políticas públicas nas áreas econômica e social. Volume 1. Brasília: Ipea, 2009, pp. 55-121.

COBB, Roger Cobb; ROSS, Jennie-Keith Ross e ROSS Marc Howard, "Agenda Building as a Comparative Political Process". The American Political Science Review, Vol. 70, No. 1 (Mar., 1976), pp. 126-138.

COHEN, Percy S., Teoria Social Moderna. Tradução de Christiano Monteiro Oiticica. Rio de Janeiro: Zahar, 1970.

CORSI, Giancarlo, "Redes de la Exclusión”. In SABIDO, Fernando Castañeda e VÁZQUEZ, Angélica Cuéllar (Coord.), Redes de Inclusión: la construcción social de la autoridad. México: Facultad de Ciencias Políticas y Sociales; UNAM; Miguel Ángel PORRÚA, 1998, pp. 29-43.

; DE GIORGI, Rafaelle, Ridescrivere la Questione Meridionale. Lecce: Pensa Multimedia, 1998.

COSTA, Fernando Braga da, Homens Invisíveis: relatos de uma humilhação social. São Paulo: Globo, 2004.

DAHL, Robert, Um Prefácio à Teoria Democrática. Rio de Janeiro: Jorge Zahar, 1989.

DAHRENDORF, Ralf, Ensaios de Teoria da Sociedade. Tradução de Regina Lúcia M. Morel. Rio de Janeiro: Zahar, 1974.

DE GIORGI, Rafaelle, "Introducción”. In Fernando Castañeda SABIDO e Angélica Cuéllar VÁZQUEZ (Coord.), Redes de Inclusión: la construcción social de la autoridad. México: Facultad de Ciencias Políticas y Sociales; UNAM; Miguel Ángel PORRÚA, 1998, pp. 9-13.

, "Redes de la Inclusión". In Fernando Castañeda SABIDO e Angélica Cuéllar VÁZQUEZ (Coord.), Redes de Inclusión: la construcción social de la autoridad. México: Facultad de Ciencias Políticas y Sociales; UNAM; Miguel Ángel PORRÚA, 1998, pp. 17-28.

DELGADO, Maurício Godinho, Curso de Direito do Trabalho. São Paulo: LTR, 2005. 
DI MAGGIO, Paul; LOCH, Hugh, "Socially Embedded Consumer Transactions: for what kind of purchases do people most often use networks?". American Sociological Review, 1998, vol. 63, pp. 619-637.

DOWNS, Anthony, Uma Teoria Econômica da Democracia. São Paulo: EDUSP, 2001.

DRAKE, Anna Marie, Constructing Democratic Space: inclusion, efficacy and protest in deliberative democratic theory. Thesis submitted to the Department of Political Studies in conformity with the requirements for the degree of Doctor of Philosophy. Queen's University: Kingston, Canada, 2008.

DREPPER, Thomas, "On the Desideratum of a Society Theory of Organizations in the Work of Niklas Luhmann”, in: SEIDL, David \& BECKER, Kai (Eds.), Niklas Luhmann and Organizational Studies. Copenhagen: Liber \& Copenhagen Business, 2005, pp. 169-188.

DULCE, María José Fariñas, La Sociologia del Derecho de Marx Weber. Madrid: Civitas, 1991.

DURKHEIM, Émile, Da Divisão do Trabalho Social. São Paulo: Martins Fontes, 1999.

EARL, Jennifer, SOULE, Sarah A. e McCARTHY, John D., "Protest under Fire? Explaining the Policing of Protest”. American Sociological Review, Vol. 68, No. 4 (Aug., 2003), pp. 581-606.

EASTON, David, "A Re-Assessment of the Concept of Political Support". British Journal of Political Science, Vol. 5, No. 4 (Oct., 1975), pp. 435-457.

FAORO, Raymundo, Os Donos do Poder: formação do patronato político brasileiro. Rio de Janeiro: Globo, 2001.

FARIA, José Eduardo, O Direito na Economia Globalizada. São Paulo: Malheiros, 1999.

FERRARY, Michel, "Trust and Social Capital in the Regulation of Lending Activities". Journal of Socio-Economics, 31 (2003), pp. 673-699.

FERRAZ JR., Tércio Sampaio, Introdução ao Estudo do Direito: Técnica, Decisão e Dominação. São Paulo: Atlas, 2007. 
, “Justiça Material como um Código Fraco na Comunicação Normativa",

in Estudos de Filosofia do Direito: reflexões sobre o poder, a liberdade, a justiça e o direito, pp. 231-244.

FOERSTER, Heinz von, Observing Systems. Seaside: Intersystems Publications, 1981.

FOUCAULT, Michel, Vigiar e Punir. Petrópolis: Vozes, 1971.

FRANCO, Maria Sylvia de Carvalho, Homens Livres na Ordem Escravocrata. São Paulo: Kairós, 1983.

GANGL, Amy, "Procedural Justice Theory and Evaluations of the Lawmaking Process". Political Behavior, Vol. 25, No. 2 (Jun., 2003), pp. 119-149.

GIBSON, J. L.; CALDIERA, G. A. e SPENCE, L. K., "The Supreme Court and the U.S. Presidencial Election of 2000: wounds, self-inflicted or otherwise?" British Journal of Political Science 33, 2003, pp. 535-556.

GRAFSTEIN, Robert, “The Legitimacy of Political Institutions”. Polity, Vol. 14, No. 1 (Autumn, 1981), pp. 51-69.

GRANOVETTER, Mark, "Economic Action and Social Structure: The Problem of Embeddedness". American Journal of Sociology, Volume 91, Issue 3 (Nov., 1985), pp. 481-510.

, "The Impact of Social Structure on Economic Outcomes". Journal of Economic Perspective, Volume 19, Number 1 (Winter 2005), pp. 33-50.

GREIF, Avner, "Self Enforcing Institutions: comparative and historical institutional analysis". Stanford University - Prepare for presentation in European School on New Institutional Economics (ESNIE), 2004.

GUASTINI, Ricardo, "La Constitucionalización del Ordenamiento Jurídico: El Caso Italiano". In CARBONELL, Miguel (Ed.), Neoconstitucionalismo(s). Madrid: Trotta, 2003, pp. 49-74.

HABERMAS, JÜRGEN, A Constelação Pós-Nacional: ensaios políticos. São Paulo: Littera Mundi, 2001.

, Faktizität und Geltung: Beiträge zur Diskurtheorie des Rechts und des demokratischen Rechtsstaats. Frankfurt am Main: Suhrkamp, 1992. 
, Legitimation Crisis. London: Heinemann, 1976.

, Mudança Estrutural da Esfera Pública. Rio de Janeiro: Tempo Brasileiro, 2003.

, Theorie des Kommunikativen Handelns. Frankfurt am Main: Suhrkamp, 1995.

HALFMANN, Jost, "Der moderne Nationalstaat als Lösung und Problem der Inklusion in das politische System”. In HELMANN, Karl-Uwe e SCHMALZ-BRUNS, Rainer (Hrsg), Theorie der Politik: Niklas Luhmanns politische Soziologie. Frankfurt am Main: Suhrkamp, 2002, pp. 261-286.

HART, H. L., The Concept of Law. Oxford: Oxford University Press, $1997 .$.

HEGEL, Friedrich, Selections. New York: C. Scribner's Sons, 1929.

HOBBES, Thomas, Leviathan. Oxford: Blackwell, 1946.

HOLANDA, Sérgio Buarque de, Raízes do Brasil. São Paulo: Companhia das Letras, 1995.

HOLMES, Stephen, "Lineages of the Rule of Law". In MARAVALL, José María e PRZEWORSKI, Adam (Eds.), Democracy and the Rule of Law. Cambridge: Cambridge University Press, 2003, pp. 19-61.

HUNTINGTON, Samuel, A Ordem Politica nas Sociedades em Mudança. Tradução de Pinheiro de Lemos. São Paulo: Forense Universitária, 1975.

KANT, Immanuel, Introducción a la Teoría del Derecho. Madrid: Centro de Estudios Constitucionales, 1978.

KELSEN, Hans, Teoria Pura do Direito. Tradução de João Baptista Machado. São Paulo: Martins Fontes, 2000.

LANGE, Stephan, "Die politische Utopie der Gesellschaftssteuerung". In Karl-Uwe HELMANN e Rainer Schmalz-Bruns (Hrsg), Theorie der Politik: Niklas Luhmanns politische Soziologie. Frankfurt am Main: Suhrkamp, 2002, pp.171-193.

LAVALLE, Adrián Gurza; HOUTZAGER, Peter e CASTELlO, Graziela, "Representação Política e Organizações Civis: Novas Instâncias de Mediação e o 
Desafio da Legitimidade". Revista Brasileira de Ciências Sociais, vol. 21, n 60, 2006, pp. 43-66.

LEYDERSDORFF, Loet, "Luhmann Reconsidered: Steps Towards an Empirical Research Programme in the Sociology of Communication?". Forthcoming in Colin GRANT (Ed.), Beyond Universal Pragmatics: Essays in the Philosophy of Communication. Oxford: Peter Lang.

LUHMANN, Niklas, Die Politik der Gesellschaft. Frankfurt am Main: Suhrkamp, 2000. , Die Wirtschaft der Gesellschaft. Frankfurt am Main: Suhrkamp, 1988.

, "Globalization or World Society: How to Conceive of Modern Society?". International Review of Sociology Mar 97, Vol. 7 Issue 1, pp. 67-80.

, Inclusión y Exclusión, in: LUHMANN, Niklas, Complejidad y Modernidad: de la unidad a la diferencia. Tradução de Josetxo Berian y José María García Blanco. Madrid: Trotta, 1998, pp. 167-195.

, La Sociedad de la Sociedad. Ciudad de México: Herder, 2007. , Law as a Social System. Oxford: Oxford University Press, 2004. , Legitimation durch Verfahren. Frankfurt am Main: Suhrkamp, 1983. "Machtkreislauf und Recht in Demokratien". Zeitschrift für Rechtssoziologie 2, 1981, pp. 158-167.

, Ökologische Kommunikation: kann die moderne Gesellschaft sich auf ökologishe Gefährdungen einstellen? Wiesbaden: Verlag für Sozialwissenschaften, 2008.

, "Operational Closure and Structural Coupling: the Differentiation of the Legal System”. Cardozo Law Review, n. 5, v. 13, march 1992, pp. 1419-1441. Organisation und Entscheidung. Opladen/Wiesbaden: Westdeutscher Verlag, 2000. - Organización y Decisión. Autopoiesis, acción y entendimiento comunicativo. Tradução de Darío Rodrigues Mansilla. Rubí (Barcelona): Anthropos; México: Universidad Iberoamericana; Santiago de Chile: Instituto de Sociología, Pontificia Universidad Católica de Chile, 1997. 
, Poder. Brasília: UNB, 1985.

, “Quod Omnes Tangit: remark on Jürgen Habermas's Legal Theory. In ROSENFELD, Michel; ARATO, Andrew(Ed.), Habermas on Law and Democracy: critical exchanges. Berkeley: University of California Press, 1998, pp. 157-172.

, Social Systems. Stanford: Stanford University Press, 1995.

_, Sociologia do Direito. Rio de Janeiro: Tempo Brasileiro, 1983.

, Soziologie des Risikos. Berlin, New York: de Gruyter, 1991.

, Vertrauen: ein Mechanismus der Reduktion sozialer Komplexität.

Stuttgart: Lucius \& Lucius, 2000.

, “Why Does Society Describes Itself as Postmodern?”. Cultural Critique,

No. 30, The Politics of Systems and Environments, Part I (Spring, 1995), pp. 171-186.

; FUCHS, Stephen, "”What is the Case?" and "What Lies behind It?" The

Two Sociologies and the Theory of Society". Sociological Theory, Vol. 12, No. 2 (Jul., 1994), pp. 126-139.

LYOTARD, Jean-François, La Condition Postmoderne: rapport sur le savoir. Paris: Éditions de Minuit, 1979.

MAHONEY, James, "Path Dependence in Historical Sociology". Theory and Society, Vol. 29, No. 4. (Aug., 2000), pp. 507-548.

MARCH, J.G. e SIMON, H.A. Organizations. New York: Blackwell Publishers, 1958.

MARSHALL, T.H., Class, Citizenship and Social Development. Westport: Greenwood Press, 1973.

MARTONE, Celso, "Instituições, Setor Público e Desenvolvimento: o caso do Brasil”. Informações Fipe, 327, 2007, pp. 16-21.

MASCARO, Alysson Leandro, Crítica da Legalidade e do Direito Brasileiro. São Paulo: Quartier Latin, 2008.

MATURANA, Humberto e PÖRKSEN, Bernhard, Del Ser al Hacer: los orígenes de la biologia del conocer. Santiago: JCSAEZ, 2004. 
MAURO, Paolo, "Corruption and Growth". The Quarterly Journal of Economics, Vol. 110, No. 3, 1995, pp. 681-712.

, "Corruption and the composition of Government Expenditure". Journal of Public Economics, 69, pp. 263-279.

MAYER, Otto, Droit Administratif Allemand. Paris, V. Giard \& E. Briére, 1903.

MERTON, Robert K., Sociologia: Teoria e Estrutura. Tradução de Miguel Maillet. São Paulo: Mestre Jou, 1970.

MIGUEL, Luís Felipe, "Um Ponto Cego nas Teorias da Democracia: os meios de comunicação”. Revista BIB, n. 49, 2000.

MOELLER, Hans-Georg, Luhmann Explained. Chicago e La Salle: Open Court, 2006.

MONTEAGUDO, José Galindo, "La Teoría Sistémica de Niklas Luhmann: Alcances e Limites", in: LUHMANN, Niklas, La Sociedad de la Sociedad. Ciudad de México: Herder, 2007.

MOISÉS, José Álvaro, "Cidadania, Confiança e Instituições Democráticas”. Lua Nova, 65, 2005, pp. 71-93.

, “Cultura Política, Instituições e Democracia: lições da experiência brasileira". Revista Brasileira de Ciências Sociais, Vol. 23, nº 66, 2008, pp. 11-43.

NACOS, Brigitte; BLOCH-ELKON, Yaeli and SHAPIRO, Robert, "Prevention of Terrorism in Post-9/11 America: New Coverage, Public Perceptions, and the Politics of Homeland Security”. Terrorism and Political Violence 20(1) (2008).

NEVES, Marcelo, A Constitucionalização Simbólica. São Paulo: Martins Fontes, 2007.

____ "Die Staaten im Zentrum und die Staaten an der Peripherie: Einige Probleme mit Niklas Luhmanns Auffassung von den Staaten der Weltgesellschaft". Soziale Systeme: Zeitschrift für soziologische Theorie 12, 2006, pp. 247-273. , Entre Têmis e Leviatã: Uma Relação Difícil. São Paulo: Martins Fontes, 2006. , "E se Faltar o Décimo Segundo Camelo? Do direito expropriador ao direito invadido". In: ARNAUD, André-Jean e LOPES JR, Dalmir, Niklas Luhmann: do 
sistema social à sociologia jurídica. Tradução de Dalmir Lopes Jr; Daniele Andréa da Silva Manão e Flávio Elias Riche. Rio de Janeiro: Lumen Juris, 2004, pp. 145-173.

, "From the Autopoiesis to the Allopoiesis of Law". Journal of Law and Society, Volume 28, Number 2, June 2001, pp. 242-264.

, Transconstitucionalismo. Tese apresentada ao concurso de provas e títulos para provimento do cargo de Professor Titular na área de direito constitucional, junto ao Departamento de Direito do Estado da Faculdade de Direito da Universidade de São Paulo. São Paulo, 2009.

O'DONNEL, Guillermo, "Poliarchies and the (Un)Rule of Law in Latin American". Paper presented at the Meeting of the Latin American Studies Association. Chicago, September 1998.

OFFE, Claus, Capitalismo Desorganizado: transformações contemporâneas do trabalho e da política. São Paulo: Brasiliense, 1994.

, Problemas Estruturais do Estado Capitalista. Rio de Janeiro: Tempo Brasileiro, 1984.

__ "The Utopia of the Zero-Option: modernity and modernization as normative political criteria”. Praxis International, Issue 1, 1987, pp. 1-24.

OPP, Karl-Dieter e ROEHL, Wolfgang, "Repression, Micromobilization, and Political Protest”. Social Forces, Vol. 69, No. 2 (Dec., 1990), pp. 521-547.

PARSONS, Talcott, "On the Concept of Influence". The Public Opinion Quarterly, Vol. 27, No. 1 (Spring, 1963), pp. 37-62.

, "On the Concept of Political Power". Proceedings of the American Philosophical Society, Vol. 107, No. 3, 1963, pp. 232-262.

PERROW, Charles, "A Society of Organizations". Theory and Society, Vol. 20, No. 6 (Dec., 1991), p. 725-762.

PERUZZOTTI, Enrique, "Modernization and Juridification in Latin America: A Reassessment of the Latin American Developmental Path”. Thesis Eleven, 1999, 58, pp. $59-82$. 
POLANYI, Karl, The Great Transformation: the political and economic origins of our time. Boston: Beacon Press, 2001.

POLLACK, Malla, “O Alto Custo de Não se ter Direitos Positivos, uma Perspectiva dos Estados Unidos”. In SALET, Ingo Wolfgang; TIMM, Luciano Benetti (orgs.), Direitos Fundamentais: orçamento e reserva do possível. Porto Alegre: Livraria do Advogado, 2008, pp. 363-389.

POPPER, Karl, A Lógica da Pesquisa Científica. São Paulo: Cultrix, 2006.

ROSE-ACKERMAN, Susan, Corruption and Government: causes, consequences and reform. Cambridge: Cambridge University Press, 1999.

RODRÍGUES, Darío e TORRES NAFARRATE, Javier, “Autopoiesis: La Unidad de una Diferencia: Luhmann y Maturana”. Sociologias, Porto Alegre, ano 5, nº 9, jan/jul 2003, pp. 106-140.

SANTOS, Boaventura de Sousa, Democratizar a Democracia: os caminhos da democracia participativa. Rio de Janeiro: Civilização Brasileira, 2002.

, "Notas sobre a História Jurídico-Social de Pasárgada". In: SOUTO, Cláudio e FALCÃO, Joaquim (orgs.), Sociologia e Direito. São Paulo: Pioneira, 1999.

SANTOS, Cláudio Hamilton dos, GENTIL, Denise Lobato, "A CF/88 e as Finanças Públicas Brasileiras”. In CARDOSO JR., José Celso (org.), A Constituição Brasileira de 1988 Revisitada: recuperação histórica e desafios atuais das políticas públicas nas áreas econômica e social, Volume 1. Brasília: Ipea, 2009, pp. 123-160.

SANTOS, Wanderley Guilherme dos, Cidadania e Justiça: a política social na ordem brasileira. Rio de Janeiro: Campus, 1979.

SARLET, Ingo Wolfgang; TIMM, Luciano Benetti (Orgs.), Direitos Fundamentais: orçamento e reserva do possível. Porto Alegre: Livraria do Advogado, 2008.

SCOTT, Robert E., "The Limits of Behavorial Theories of Law and Social Norms". Virginia Law Review, nº 86, 2000, pp. 1603-1647.

SCHULTZ, Vicki, “The Sanitized Workplace”. Yale Law Journal, 112, 2003, pp. 20632193. 
SEIDL, David, “The Basic Concepts of Luhmann's Theory of Social Systems”, in SEIDL, David \& BECKER, Kai (Eds.), Niklas Luhmann and Organizational Studies. Copenhagen: Liber \& Copenhagen Business, 2005, pp. 19-51.

SHAPIRO, Ian, "Problems, Methods and Theories in the Study of Politics, or What's Wrong with Political Science and What to do About It". Political Theory, Vol. 30, $\mathrm{n}^{\circ} 4$, (Aug 2002), pp. 596-619.

SILVA, Marcos Fernandes G. da, Ética e Economia. Rio de Janeiro: Campus-Elsevier, 2006.

SILVA, Virgílio Afonso da, Direitos Fundamentais: conteúdo essencial, restrições e eficácia. São Paulo: Malheiros, 2009.

, "Ulisses, as Sereias e o Poder Constituinte Derivado: sobre a inconstitucionalidade da dupla revisão e da alteração no quorum de 3/5 para aprovação de emendas constitucionais". Revista de Direito Administrativo, 226, 2001, pp. 11-32.

SOUZA, Jessé, A Construção Social da Subcidadania: para uma sociologia política da modernidade periférica. Belo Horizonte: Editora UFMG; Rio de Janeiro: IUPERJ, 2003.

STICHWEH, Rudolph, "Die Entstehung einer Weltöffentlichkeit". In Hartmut KAELBLE, Martin KIRSCH e Alexander SCHMIDT-GERNIG (orgs.), Transnationale Öffentlichkeiten und Identitäten im 20. Jahrhundert. Frankfurt am Main: Campus, 2002, pp. 57-66.

, "Systems Theory as an Alternative to Action Theory? The Rise of 'Communication' as a Theoretical Option”. Acta Sociologica, Vol. 43, No. 1 (2000), pp. $5-13$.

SUNSTEIN, Cass; HOLMES, Stephen, The Cost Of Rights: why liberty depends on taxes. New York: W.W. Norton \& Company, 1999.

TAYLOR, Charles, As Fontes do Self: a construção da identidade moderna. Tradução: Adail Ubirajara Sobral e Dinah de Abreu Azevedo. São Paulo: Loyola, 1997. 
TEUBNER, Gunther. "Altera Pars Audiatur: Law in the Collision of Discourses". In: RAWLINGS, Richard (Ed.), Law, Society and Economy. Oxford: Oxford University Press, 1997, pp. 150-176.

TORRES, Ricardo Lobo, "O Mínimo Existencial, os Direitos Sociais e Os Desafios de Natureza Orçamentária”. In SALET, Ingo Wolfgang; TIMM, Luciano Benetti (orgs.), Direitos Fundamentais: orçamento e reserva do possível. Porto Alegre: Livraria do Advogado, 2008, pp. 69-86.

TORRES NAFARRATE, Javier, Luhmann: La Política como Sistema. Ciudad de México: Fondo de Cultura Económica, 2004.

TYLER, Tom R., Why People Obey the Law. Princeton: Princeton University Press, 2006.

VILLAS BÔAS FILHO, Orlando, Teoria dos Sistemas e o Direito Brasileiro. São Paulo: Saraiva, 2009.

VIEIRA Fabíola Sulpino; ZUCCHI, Paola, “Distorções Causadas Pelas Ações Judiciais à Política de Medicamentos no Brasil”. Revista de Saúde Pública / Journal of Public Health, v. 41, 2007, pp. 214-222.

WEBER, Max, A Ética Protestante e o Espírito do Capitalismo. São Paulo: Martin Claret, 2002.

, Economia e Sociedade. Brasília; UNB, 2000. 


\section{RESUMO}

A presente dissertação tem como o objetivo discutir as dificuldades adicionais de legitimação do Estado Democrático de Direito na Modernidade Periférica, a partir da observação do caso brasileiro. O marco teórico adotado será a teoria dos sistemas de Niklas Luhmann. Para Luhmann, o Estado Democrático de Direito deve ser compreendido como resultado da diferenciação entre o sistema político e o sistema jurídico. Os traços característicos da realidade brasileira (como a exclusão, o personalismo e a corrupção) prejudicam o cumprimento das funções desses dois sistemas funcionais. A falta de confiabilidade, equidade e acessibilidade dos procedimentos estatais, por sua vez, compromete a sua capacidade de absorver e intermediar a conflituosidade social, prejudicando a aceitação das decisões estatais.

Palavras-chave: legitimação do Estado Democrático de Direito - modernidade periférica - exclusão - corrupção - ineficácia dos direitos fundamentais. 


\section{ABSTRACT.}

This work has as objective to discuss the additional difficulties of legitimation of the democratic state of law in Peripheral modernity, from the observation of the Brazilian case. The theoretical framework adopted is the systems theory of Niklas Luhmann. For Luhmann, the democratic state must be understood as the result of differentiation between the political system and legal system. The characteristics of the Brazilian reality (such as exclusion, personalism and corruption) affect the functions of these two functional systems. The lack of reliability, equity and accessibility of state procedures, in turn, compromises their ability to absorb and mediate the social conflicts, undermining the acceptance of government decisions.

Keywords: legitimation of the democratic state of law - peripheral modernity exclusion - corruption - ineffectiveness of fundamental rights. 